Enhancement of impact toughness and damage behaviour of natural fibre composites and their hybrids through novel improvement techniques: a review

M. Muneer Ahmed ${ }^{\mathrm{a}, \mathrm{b}}$, H. N. Dhakal ${ }^{\mathrm{a} *}$, Z. Y. Zhang $^{\text {a }}$, A. Barouni ${ }^{\text {a }}$, R. Zahari ${ }^{b}$ Advanced Materials and Manufacturing (AMM) Research Group, School of Mechanical and Design Engineering,

University of Portsmouth, Anglesea Road, Anglesea Building, Portsmouth, Hampshire, PO1 3DJ, U.K.

${ }^{\mathrm{b}}$ Department of Systems Engineering, Military Technological College, Al Matar Street, Muscat 111, Oman.

*Correspondence: hom.dhakal@port.ac.uk

\begin{abstract}
:
The importance of natural fibres over synthetic fibres have gained significant attention in the research area, due to their higher specific strength, stiffness, lightweight and inexpensive. Natural fibre composites used in various applications are often susceptible to moisture absorption and various critical loadings scenarios during their service life such as low-velocity impact damages which is a concern for structural and non-structural applications. For enhancing the toughness of natural fibres hybridisation with synthetic fibres is essential. This paper examines the essential information critically from the published literature influencing the morphological characteristics, fracture toughness, damage tolerance and impact resistance of natural fibre reinforced and their hybrid composites. Following this, this review paper critically analyses the novel improvement techniques suitable for natural fibre composites for damage tolerance and impact resistance behaviours.
\end{abstract}

Keywords: Natural fibre; Synthetic fibre; Hybrid composites; Morphological characteristics; Damage tolerance; Fracture toughness; Impact resistance. 


\section{List of Nomenclatures}

\begin{tabular}{|c|c|c|}
\hline PA & - & Propionic Anhydride \\
\hline MA & - & Methacrylic Anhydride \\
\hline $\mathrm{PP}$ & - & PolyPropylene \\
\hline LDPE & 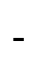 & Low-Density Polyethylene \\
\hline HDPE & . & High-Density Polyethylene \\
\hline PS & - & Polystyrene \\
\hline PLA & - & Polylactic Acid \\
\hline PU & - & Polyuretane \\
\hline HMPP & - & High Modulus Polypropylene \\
\hline UHMWPE & - & Ultra-High-Molecular-Weight Polyethylene \\
\hline rHDPE & & recycled High-Density Polyethylene \\
\hline vHDPE & - & virgin High-Density Polyethylene \\
\hline EG & - & Ethylene Glycol \\
\hline ASTM & - & American Society of Testing Materials \\
\hline $\mathrm{DCB}$ & - & Double Cantilever beam method \\
\hline MBT & & Modified Beam theory \\
\hline $\mathrm{MCC}$ & 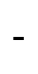 & Modified Compliance Calibration \\
\hline $\mathrm{CC}$ & - & Compliance Calibration \\
\hline ENF & & End Notch Flexure test \\
\hline ELS & - & End- Load Split test \\
\hline NFRPCs & - & Natural Fibre Reinforced Polymer Composites \\
\hline NFRC & - & Natural Fibre Reinforced Composites \\
\hline NFPC & - & Natural Fibre Polymer Composite \\
\hline HFRE & - & Hybrid Fibre Reinforcement \\
\hline $\mathrm{DD}$ & & Dyneema Dyneema \\
\hline $\mathrm{CC}$ & 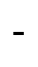 & Carbon Carbon \\
\hline $\mathrm{CD}$ & 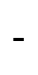 & Carbon Dyneema \\
\hline CGC & 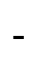 & Carbon Glass Carbon \\
\hline CG & r & Carbon Glass \\
\hline
\end{tabular}




$\begin{array}{lll}\text { CGGC } & - & \text { Carbon Glass Glass Carbon } \\ \text { SCP } & - & \text { Sandwich Composite Panels } \\ \text { FVE } & - & \text { Flax Vinyl Ester } \\ \text { FBVE }_{\mathrm{s}} & - & \text { Flax Basalt Vinyl Ester Stitched } \\ \text { FBVE }_{\mathrm{u}} & - & \text { Flax Basalt Vinyl Ester unstitched } \\ \text { WCC } & - & \text { Woven Commingled Composites } \\ \text { KCC } & - & \text { Knitted Commingled Composites } \\ \text { WC } & - & \text { Woven composites } \\ \text { UD } & - & \text { Unidirectional } \\ \text { CFRP } & - & \text { Carbon Fibre Reinforced Polymer Laminate } \\ \text { ALE } & - & \text { Arbitrary Lagrangian Element } \\ \text { CEL } & - & \text { Coupled Eulerian-Lagrangian } \\ \text { STF } & - & \text { Shear Thickening Fluid } \\ \text { CNT } & - & \text { Carbon Nanotubes } \\ \text { CS } & - & \text { Cold Spraying Technique } \\ \text { FML } & - & \text { Fibre Metal Laminates } \\ \text { MSO } & - & \text { Methacrylated Soybean Oil }\end{array}$




\section{1: Introduction}

Throughout the years, the research field has been involved in strengthening the fibre-reinforced composites. Several researchers suggested various techniques to make these materials as damage resistant and less brittle [1]. Strategies were identified to increase the matrix toughness in the fibre-reinforced composites, which has a substantial influence on the matrix-dominated composite properties [2]. However, to find a new toughness mechanism for the biological composites, there has been an increase in structural properties relation that is resilient to failure [3].

Fibres are categorized as synthetic and natural. Among the synthetic fibre, Carbon and glass are gaining more attention over the last two decades [4]. Synthetic fibre-reinforced composites provide high strength, stiffness, and extensively used in aerospace and automobile applications [5]. Synthetic fibres are consumer-friendly to waterproofing, stretching, and stain-resistant [6]. Whereas natural fibres grow rapidly in research interest for their sustainability in resources, biodegradability, low cost, and less in weight [5]. The replacement of artificial fibres with natural fibres is considerably increased in engineering applications [7]. This replacement helps to preserve the environment by reducing utilisation of artificial fibres concerning weight reduction, low material cost, and renewability [8]. Although natural fibres are weak in mechanical properties, they have good absorption capability in impact tests. Therefore, for advanced applications, high strength is required with higher mechanical properties. In such cases, the hybridisation is the possible solution for increasing the mechanical properties [9]. According to Dhakal [7], natural fibres are used for high-performance applications by hybridising with other composites. Though, few limitations in non- structural applications are high moisture content, lower strength, and stiffness properties [10]. As a solution, hybridisation with chemically modified fibres is recommended [11]. Because by adding another form of hydrophobic fibre to the hydrophilic fibre composites, it provides an efficient method and also enhances the resistance to moisture and reduces the degradation of the properties of NFPC [9].

Over the last decades, researchers are focussing on the impact and damage tolerance of composite structures, which has been revealed several design problems [7,11-14]. Such problems are complicated since the results are not solely dependent on the material parameters but also test configuration and sample configuration [15]. Also, the damage occurs in various 
forms, such as fibre/matrix debonding, surface micro buckling, matrix cracking, and fibre breakage [16]. Therefore to produce a practical design for a structure, it is vital to know the impact response, impact energy, and impact strength absorbed by the material before its failure [17].

The Impact test is an approach to evaluate the fracture toughness and notch sensitivity in composite fabric. The critical feature that affects the impact characteristics of a composite is the fracture toughness of the resin system [15]. The fracture toughness, such as Mode I and Mode II, governs the impact response of the compact material [18]. Therefore, under impact loading, the composite material can absorb a large amount of energy in the full range of damage modes [19]. The other common failure in the composite laminates is delamination. It occurs by interfaces of the laminate layers. The most critical feature in the laminates is caused by matrix cracking, shear cracks, and bending cracks due to the dynamic loadings such as low and highvelocity impact tests [20]. Generally, there are four types of impact test with respect to velocity: low velocity $(0-11 \mathrm{~m} / \mathrm{sec})$, high velocity $(>11 \mathrm{~m} / \mathrm{sec})$, ballistic impact $(>500 \mathrm{~m} / \mathrm{sec})$ and hypervelocity impact test $(>2000 \mathrm{~m} / \mathrm{sec})$. Besides, the impact events are grouped into two notable cases: low-velocity impact test with a huge mass (for instance, dropped object) and a small mass for the high-velocity impact test (for instance, runway debris). A detailed summary of types of impact tests concerning velocity shown in Table 1. Also, the stress in the composites can initiates crack between the layers and causes delamination. Besides, interlaminar performance is characterised by weakness under both shear and tensile stresses. Therefore, such stresses affect the whole performance of material discontinuities and geometry [21]. Moreover, the different aspects damaging of composite materials are illustrated in Fig. 1.

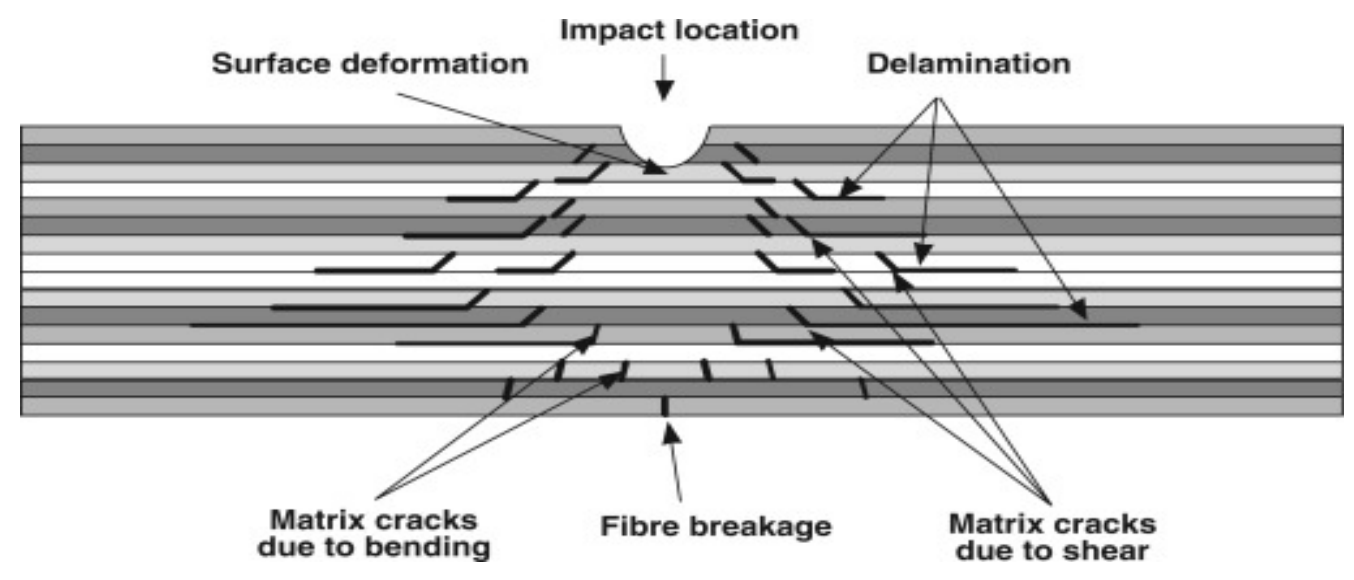


Fig. 1. Schematic description of impact location and damage mode of laminates' composite

Therefore, identifying the various damage modes and their progression towards impact is vital. The primary purpose of this paper is to review the information from the various literature articles published in impact mechanics and damage tolerance of hybrid composites. Initially, the morphological characteristics, structure and surface treatment are discussed with the challenges and comparison between natural and synthetic fibres. Following this, a detailed review on natural fibres related explicitly to materials, geometry and the damage tolerance and impact resistance of natural fibre composites and their hybrids under different loading conditions, exposed to different natural environments. Finally, a novel improvement technique on improving the damage tolerance and impact resistance for usage in various engineering applications with future perspectives are presented.

\section{Table 1}

Types of Impact tests with a velocity range [15]

\begin{tabular}{ccc}
\hline Velocity range & Test equipment & Applications \\
\hline Low velocity & Drop hammer & Dropped items \\
$0-11 \mathrm{~m} / \mathrm{sec}$ & Pneumatic accelerator & Vehicle impact crash \\
High velocity & Compresses air gun & Free falling bombs \\
$>11 \mathrm{~m} / \mathrm{sec}$ & Gas dun & Fragments owing to \\
& & the explosion \\
Ballistic impact & Compressed air gun & Military \\
$>500 \mathrm{~m} / \mathrm{sec}$ & Gas dun & Military, space vehicles
\end{tabular}

\section{2: Natural fibres, their structures and morphological characteristics as reinforcements in composites}

The characteristics of the natural fibres depend on various factors including soil conditions, climate, fibre extradition techniques and fibre processing. However, the knowledge of fibre properties is vital, which are particularly useful for the mechanical and impact performance of composites. It is, therefore, the knowledge must be permanently integrated into a processing technique that allows high volume production and processing of natural fibre composites. 
Naturals fibres are neither synthetic nor human-made; they are plants and animal sources such as oil palm, flaxseed, and jute [23]. It can be applied as a reinforcement or fillers [24]. A block diagram with a classification of natural fibres depicted in Fig. 2. Vegetable/ plant fibres such as jute, kenaf, flax, ramie, sisal, and hemp are commonly used in textile and other industrial applications [10]. Also, all vegetable fibres consist mainly of cellulose and lignin. Cellulose contains a linear chain of anhydroglucose units with semi-crystalline polysaccharide hydrophilic components that contain alcoholic hydroxyl groups [25]. Because hydroxyl is present in all-natural fibres and other polar groups in their constituents, natural fibres exhibit higher moisture absorption [26,27]. However, few disadvantages are lower impact strength, weak moisture resistance, less durability, and poor matrix fibre adhesion [28]. Irrespective of its shortcomings, natural fibres are rapidly increasing in research interest due to their sustainability in resources [29]. Also, natural fibres have a low environmental impact, low cost, low density and low machine wear.

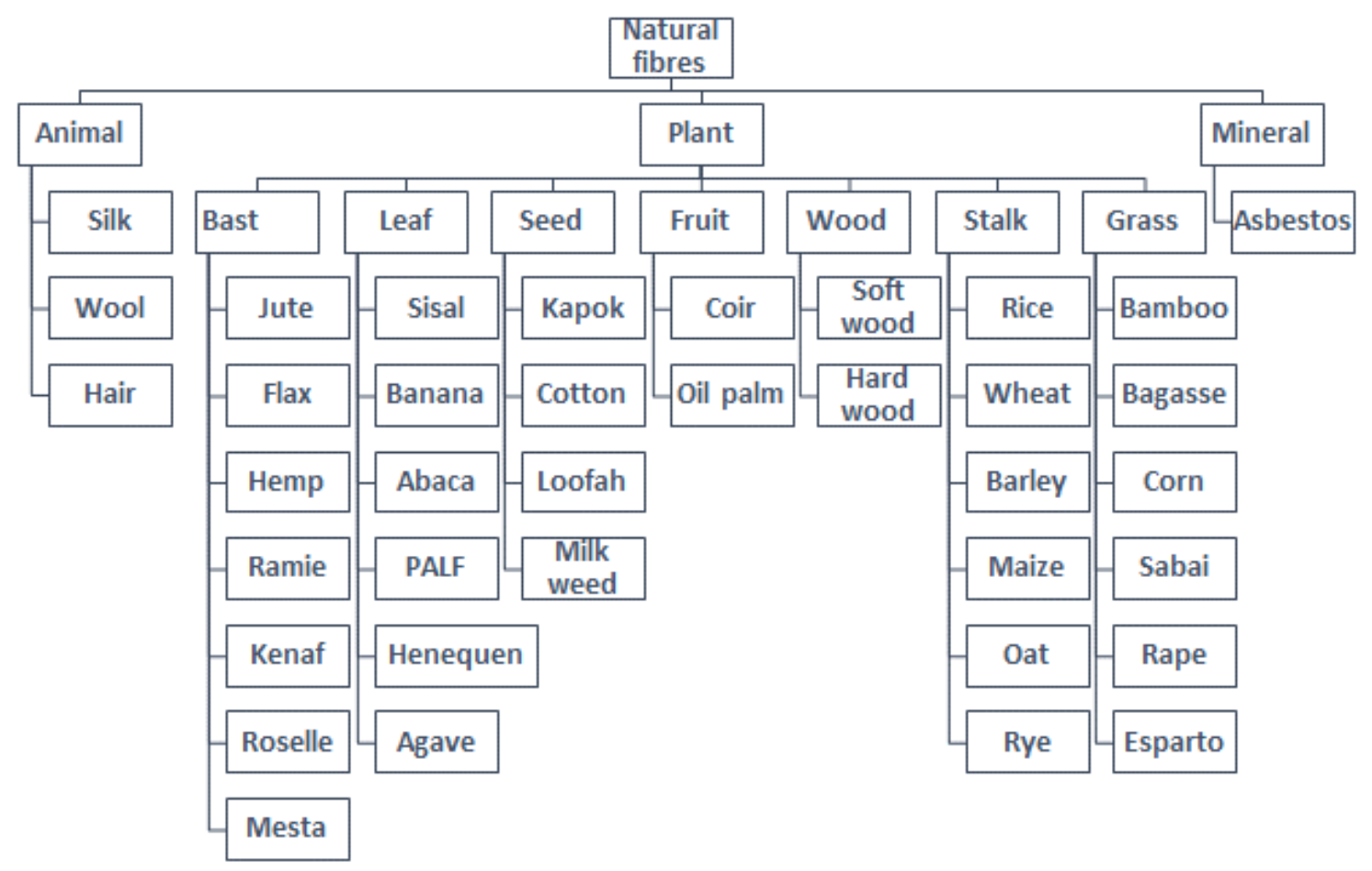

Fig. 2. Natural fibres and their classifications [30]

\subsection{Structure of bast fibres}

Bast fibres are obtained from the Phloem of the fibrous plant [31]. A flax plant stem, for instance, displayed in Fig. 3. consists of Bark, Fibre bundle and group of xylem, shives and woody core. The topmost layer is bark/skin, which is mainly responsible for the plant protection against moisture evaporation and unexpected changes in the temperature. The 
middle layer is where the fibres are located in the Phloem, appears as a bundle. The bottom layer contains xylem, shives, and woody core has a significant role in transferring water and nutrients from the centre of the fibre. As in Fig. 4. Single fibres are connected by middle lamella, a substance composed of pectin, which functions as a glue [32]. The single fibres consist of two significant walls such as primary and secondary wall; these walls surround a channel filled with protein and pectin called the lumen [32]. The primary wall possesses a rigid framework of cellulose microfibrils within a network of hemicellulose, pectin compounds and glycoprotein. Whereas the secondary wall is largest with three-layered structure (S1, S2, S3). All these layers consist of cellulose, hemicellulose, and lignin. The middle layer (S2) forms the maximum bulk of the fibre (about $70-80 \%$ of mass) $[33,34]$. Thus, the highest attribute of a single fibre is controlled by the S2 layer, and it determines the overall mechanical strength [35].

The chemical composition of the plant fibres are cellulose, hemicellulose, lignin, pectin, and wax, as shown in Fig. 5. All-plant fibres have distinctive properties because they are cultivated in a natural environment with water, sunlight, soil, and air. However, the peculiarity is that all they have the same constituents with different compositions [29]. Table 2 shows the compositions and percentage of plant fibres, amongst which banana, coir, flax, hemp, jute, pineapple, and sisal are the primary resources for industrial materials [30].

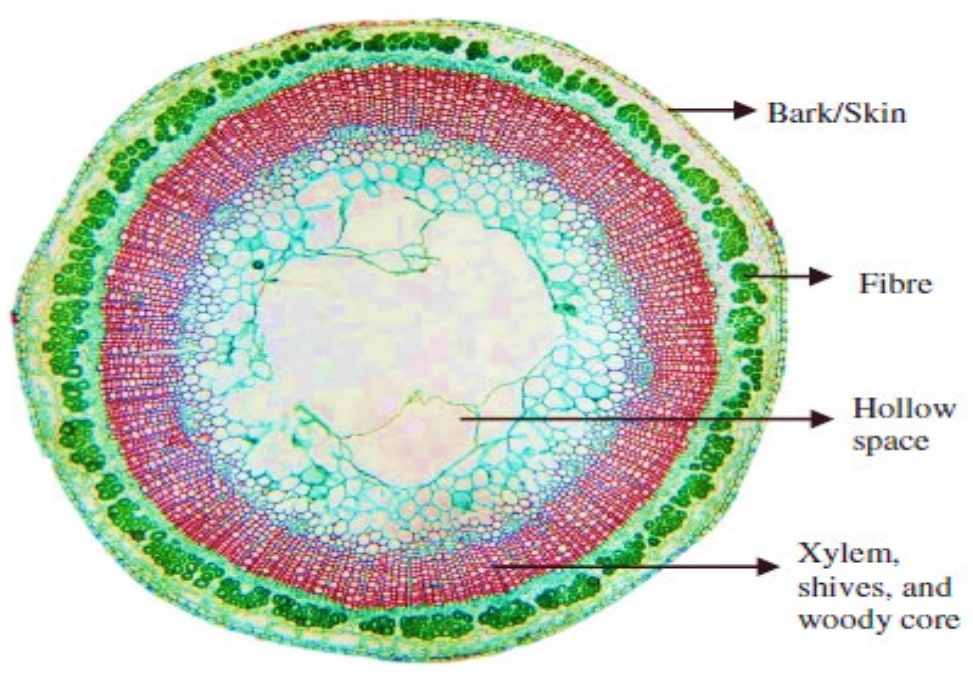

Fig. 3. Cross-section of Flax stem [31] 


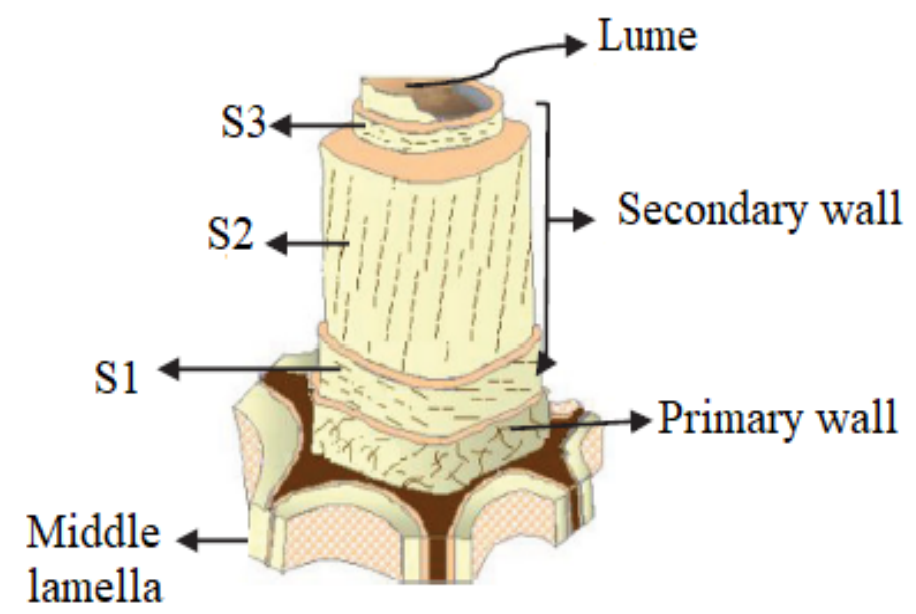

Fig. 4. Single element fibre source [31]

\section{Table 2}

Chemical composition of plant fibres [36,37]

\begin{tabular}{cccccc}
\hline Name of fibre & Cellulose & Hemicelluloses & Lignin & Pectin & Waxes \\
\hline Abaca & 62.5 & 21 & 12 & 0.8 & 3 \\
Banana & 62.5 & 12.5 & 7.5 & 4 & - \\
Bamboo & 34.5 & 20.5 & 26 & - & - \\
Coir & 46 & 0.3 & 45 & 4 & - \\
Cotton & 89 & 4 & 0.75 & 6 & 0.6 \\
Flax & 70.5 & 16.5 & 2.5 & 0.9 & - \\
Hemp & 81 & 20 & 4 & 0.9 & 0.8 \\
Jute & 67 & 16 & 9 & 0.2 & 0.5 \\
Kenaf & 53.5 & 21 & 17 & 2 & - \\
Pineapple & 80.5 & 17.5 & 8.3 & 4 & - \\
Ramie & 72 & 14 & 0.8 & 1.95 & - \\
Sisal & 60 & 11.5 & 8 & 1.2 & -
\end{tabular}


(a)

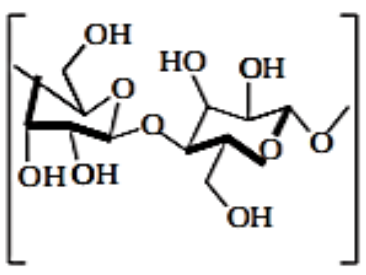

(b)

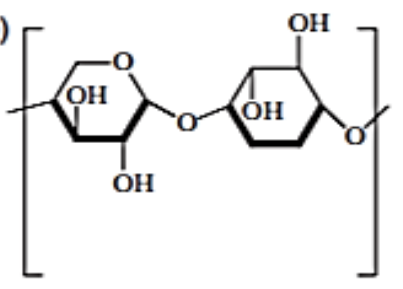

(c)

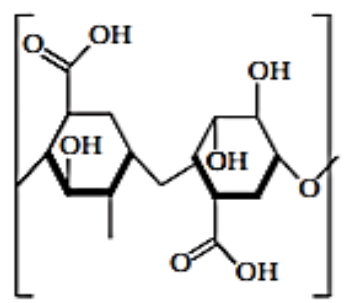

(d)

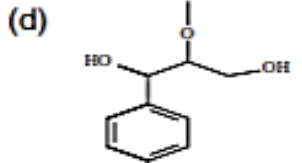

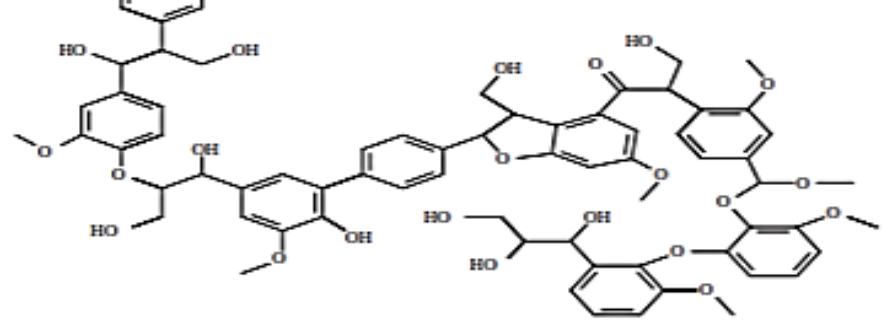

Fig. 5. Structural representations of (a) cellulose, (b) hemicellulose, (c) pectin, and (d) lignin [38].

Cellulose is the essential components of natural fibres for increasing mechanical properties. The higher the cellulose content, the greater will be the mechanical characteristics [39]. However, other compositions, such as hemicellulose and pectin, increase the moist absorption [40]. Besides, pectin has a drawback that affects natural fibres' structural and morphological properties [41].

\subsection{Morphological characteristics of natural fibre}

Bast fibres have a typical cell structure, which consists of a lumen and a thick wall [42]. Generally, the cross-sectional shapes of all-natural single fibres consist of a rounded polygonal, outer shape [43]. Perhaps, a non-uniform and irregular shape differs from one fibre to another. Typically, they are between $10 \mu \mathrm{m}$ and $50 \mu \mathrm{m}$ in diameter and $8-14 \mu \mathrm{m}$ in length [44] shown in Table 3. The plant maturity determines the lumen diameter ranging from $0.5 \mu \mathrm{m}$ to $10 \mu \mathrm{m}$, which can be short, cylindrical or elliptical $[44,45]$. According to Yamada [46], the fibre density, mechanical and dimensional characteristics will have a more substantial influence on the single fibre shape and lumen diameter. Baley [47] reported that lumen size increases with increasing diameter for flax fibre bundles. Increasing the lumen size can increase the porosity of the fibre and reduce the fibre density. Schäfer and Hornermeier [44] observed that lumen cross-section was around $70-130 \mu \mathrm{m}^{2}$, which is $13 \%-16 \%$ of the overall fibre cross-section area. Many researchers observed that tensile strength and rigidity are mainly dependent on their diameter [48-50]. As the diameter of flax [48,49], hemp [51] and jute [52-54] increases, (See 
Fig. 6) the tensile strength decreases because of Griffith's theory [55], which is used in the fracture mechanics of brittle materials. Moreover, in the case of diameter dependent on tensile strength, the author Fan M [51] reported that there are several studies related to the Ultimate tensile stress concerning the fibre diameter, but the questions related to the tensile elastic modulus dependent on diameter remains unresolved. Indeed, several authors have experimentally observed a substantial decline in modulus associated with increasing fibre diameter in the case of elemental flax [56], hemp [57] and jute [53,54].

Three techniques were commonly used for the characterisation of fibre diameter [58] they are SEM., Laser diffraction and light microscopy. Hu W [48] stated that in actual practice SEM observations of the fracture surface do not allow the surface area of the lumen to be determined. The fractography image (Fig. 7.) gives a piece of clear evidence that the geometry changes in the fibre portion, where the lumen is almost disappeared in the rupture field [42]. However, under microscopic observation (Fig. 8.) use of polarised light can identify the dislocations of the lumen in hemp fibres $[59,60]$.

\section{Table 3}

Morphological characteristics of natural fibres [61-63]

\begin{tabular}{lllllll}
\hline Plant & Hemp fibre & Flax fibre & Jute fibre & Ramie fibre & Sisal Fibre & Cotton Fibre \\
\hline Length & $5-60$ & $2-40$ & $2-3$ & $40-150$ & $2-7$ & $20-70$ \\
mm & & & & & \\
Diameter & $20-40$ & $20-23$ & 16 & 30 & 20 & $20-30$ \\
$\mu \mathrm{m}$ & & & & & & 140 \\
$\mathrm{~L} / \mathrm{D}$ & $100-2000$ & $100-2000$ & 160 & $40-150$ & 1250
\end{tabular}




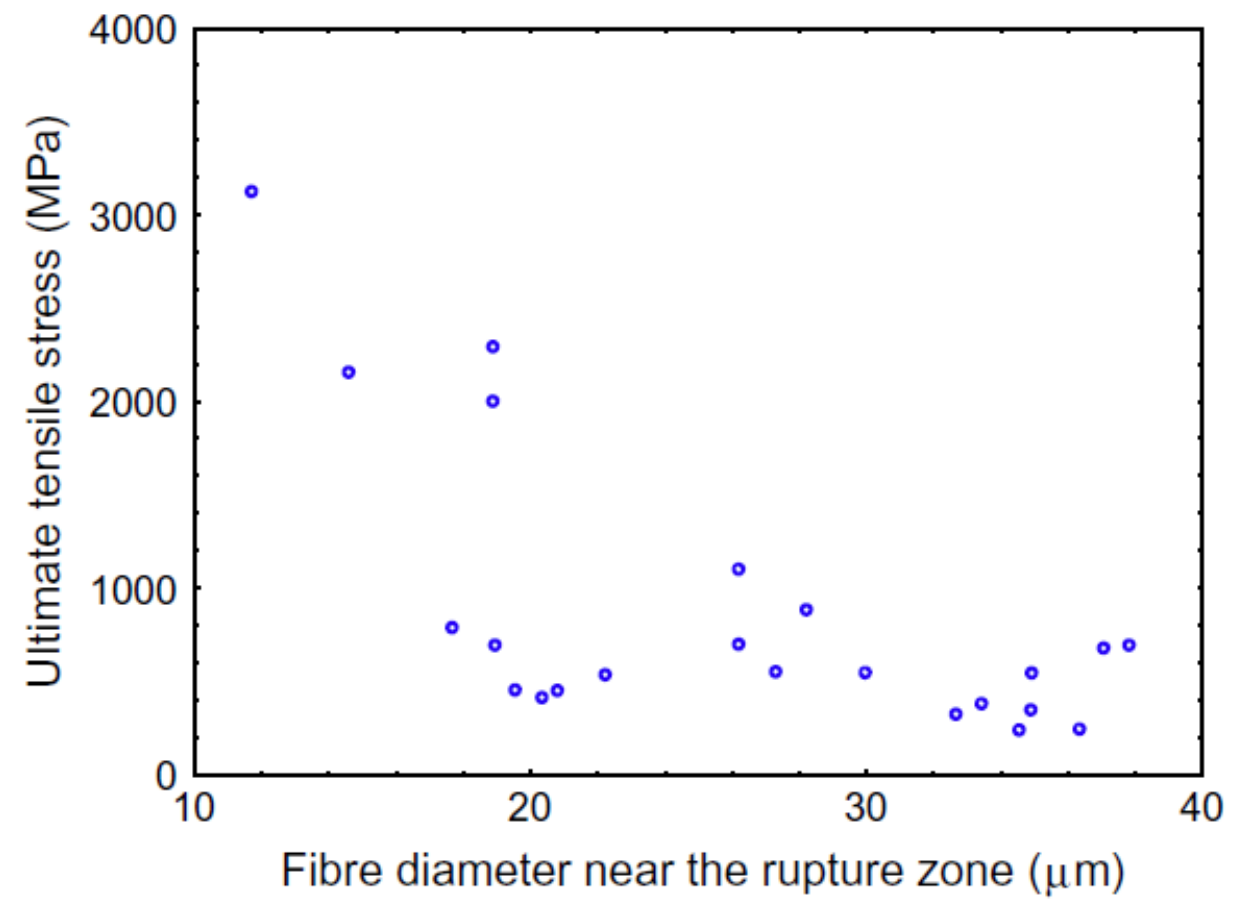

Fig. 6. Ultimate tensile strength vs Fibre diameter of hemp fibre [42]
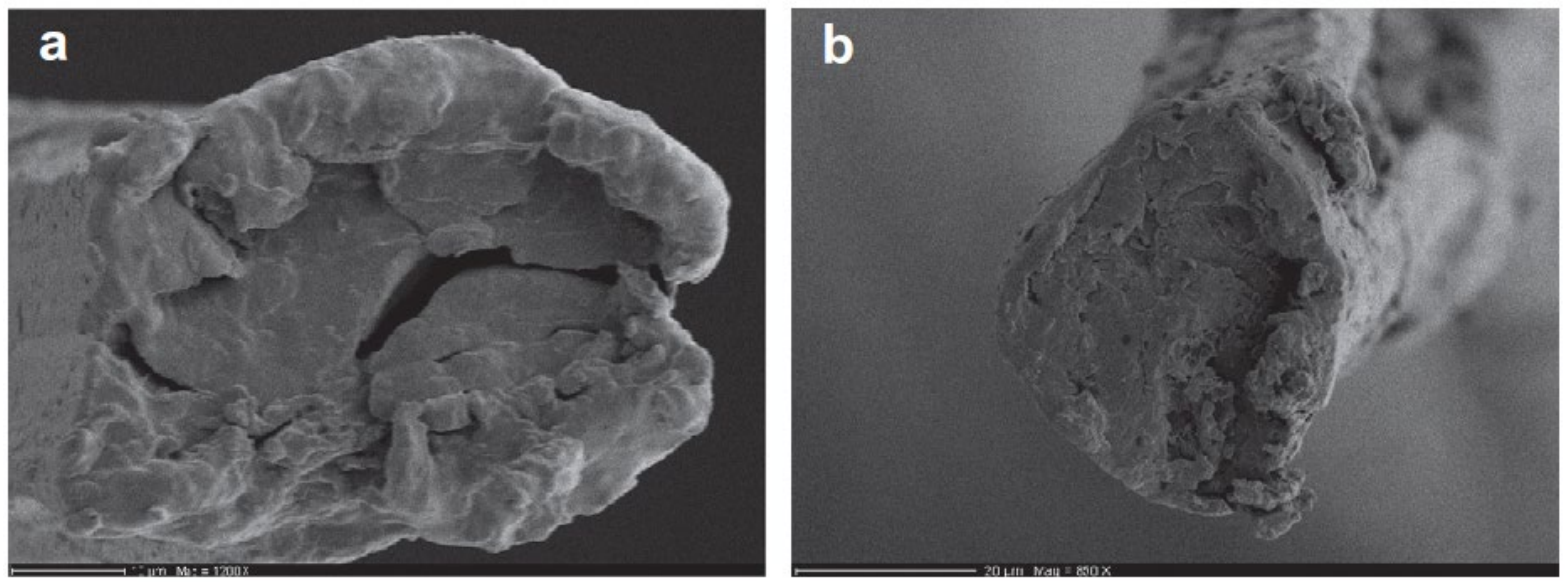

Fig. 7. SEM images of hemp fibre cross-section (a) virgin fibre and (b) failed fibre [42] 


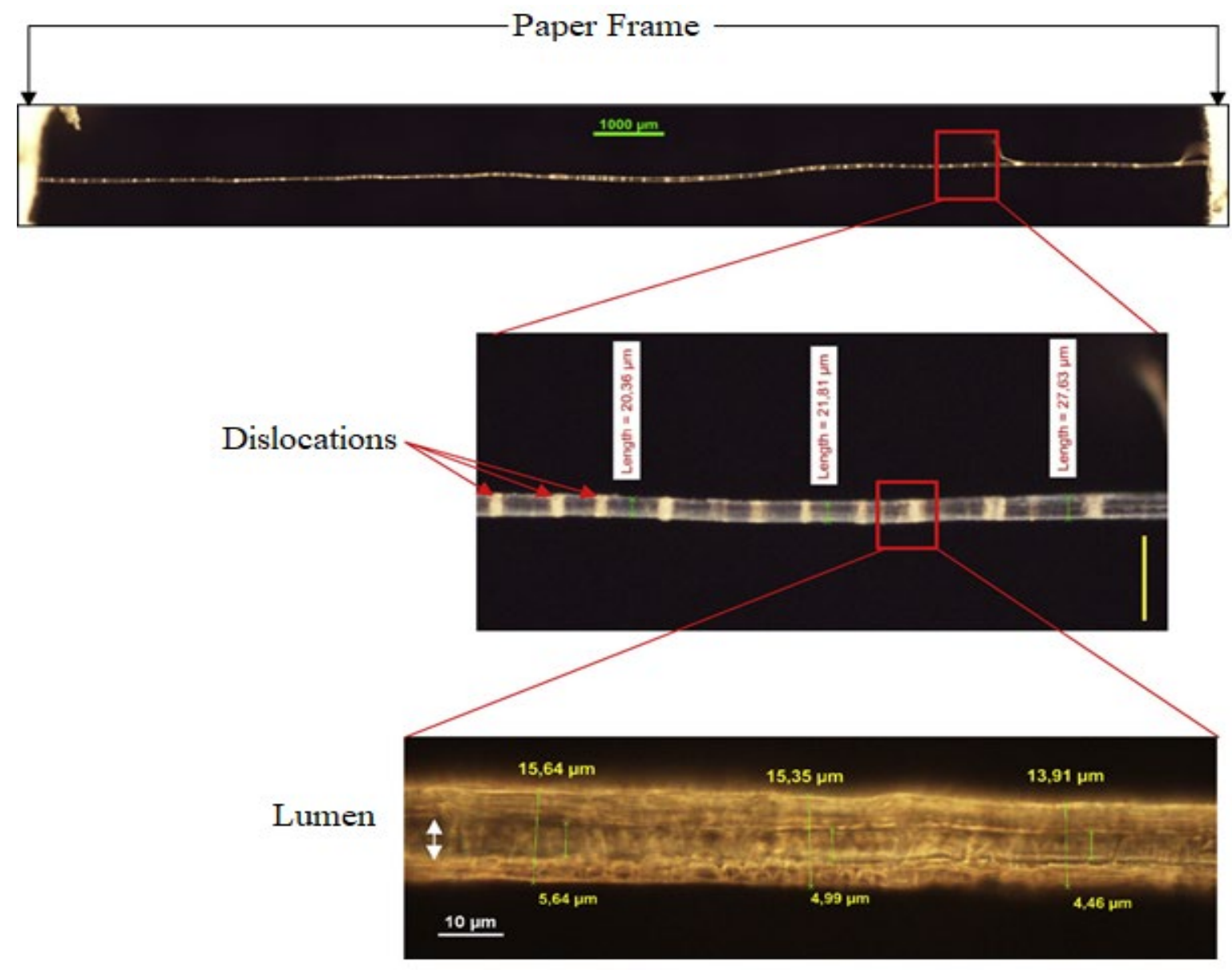

Fig. 8. Microscopic observation of polarised light images of a hemp fibre [42]

\subsection{Surface treatment of Natural fibres and their effects}

Natural fibres are prone to water absorption due to rich cellulose and hydrophilic in nature [64]. Many researchers $[65,66]$ observed that moisture content would cause significant degradation of natural fibre-reinforced composites concerning a crack in brittle matrices. To overcome the moisture content and for better bond strength, it is, therefore, primarily to apply some treatment to the surface, either physically or chemically. Trujillo et al. [67] observed that treatment of fibres partially removes the lignin, hemicellulose, waxes, and other impurities. However, there is a lower chance of moisture entering into the material by reducing the empty content of composites and improving the adhesion between the fibres and matrix. Currently, there are various techniques for natural fibre surface modifications, which helps in improving their properties. These techniques include treatment with Alkali [68], Acetylation [69,70], silane [71], Ozone [72,73], plasma [74-77], mercerisation [78-80], benzoylation [78] and grafting $[81,82]$. 
Sánchez et al. [83] presented findings on mercerisation, ozone, and plasma treatment and checked the properties of bamboo fibres- reinforced composites. They observed a substantial decline in the average surface rough value (about $30 \%$ for plasma treatment fibres and $80 \%$ for Mercerization and ozone treatment). Even Barra et al. [84] also obtained similar results. Valadez-Gonzalez et al. [85], observed that alkaline treatment has two major effects on the fibre: (1) it improves the properties, and surface roughness (2) improves cellulose treatment on fibre surfaces. Jähn et al. [86], reported that alkaline treatment has a lasting influence on the flax fibres, particularly fibre strength and stiffness. A study from van de Weyenberg et al. [87], noticed that a $30 \%$ rise in tensile properties for flax fibre - epoxy composites with the elimination of pectin. Negawo et al. [88], studied the surface morphology and structural composition of alkali $(\mathrm{NaOH})$ treated $2.5 \%, 5 \%$, and $7.5 \%$ Ensete stem fibres reinforced unsaturated polyester composites. The alkali increases the roughness of fibre surface and also provides higher mechanical performance in all concentrations. Fiore et al. [89], examined the pretreated solution of $6 \% \mathrm{NaOH}$ on kenaf- epoxy composites at room temperature for two different periods, $48 \mathrm{~h}$ and $144 \mathrm{~h}$, respectively. The untreated fibres (Fig. 9.a) indicates the impurities on the surface, at $48 \mathrm{~h}$ in the alkali removes the impurities (Fig. 9.b), after 144h heavy damage of fibre was found since the soaking time has increased. (Fig. 9.c)
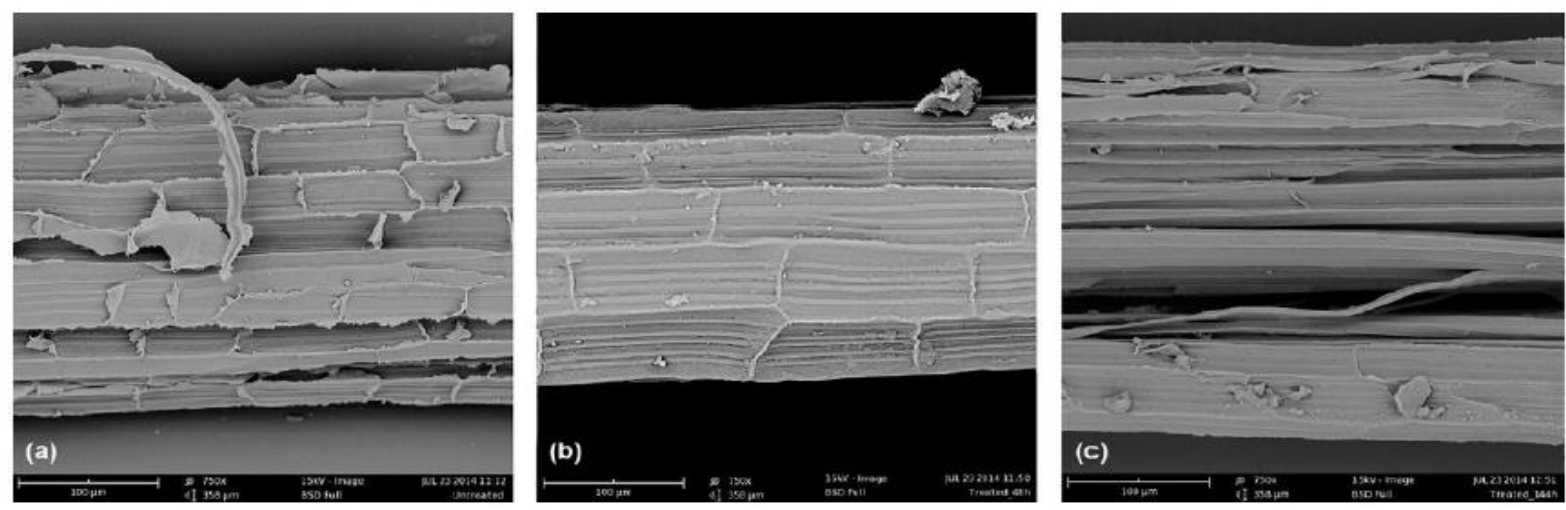

Fig. 9. S.E.M. images of Kenaf fibres (a) untreated Kenaf fibres; (b) after $48 \mathrm{~h}$ in $\mathrm{NaOH}$ solution, and (c) after $144 \mathrm{~h}[89]$.

Therefore, alkaline treatment or mercerisation is often utilised chemical treatments for natural fibres along with reinforced thermoplastics and thermoset composites [90]. Many researchers recommended that silane treatment is commercially available inorganic compounds and suitable for the surface fibre modifications [91-93]. Gang [94], discovered that silane treatment has excellent composite-bonding interfaces with increased tensile and impact properties. Liu et al. [95] observed the corn stalk fibre-reinforced composites treated with silane reaction could 
drastically reduce the water absorption and porosity, which makes poor friction performance in the silane treated corn stalk fibre composites. Therefore, for enhancing friction performance, acetylation has been documented to strengthen the adhesion of fibre-matrix [90]. Yao et al. [96] investigated the acetylation of flax/PP composites. They reported an $18 \%$ rise in acetylation had a considerable rise in the flexural and tensile strengths. Hughes et al. [97], observed that flax fibre showed better properties after coating with propionic anhydride (PA) and methacrylic. Similar results also obtained by Cantero et al. [98], by coating a vinyl group of methacrylic anhydride (MA) and hydrocarbons. A detailed summary of the chemical treatments on the function of natural fibre is illustrated in Table 4. 


\section{Table 4}

Summary of the surface treatment of natural fibres and their effects

\begin{tabular}{|c|c|c|}
\hline Treatment & Effect & References \\
\hline Alkali & $\begin{array}{l}\text { Improve fibre- matrix adhesion and helps in } \\
\text { improving the properties }\end{array}$ & [99] \\
\hline Acetylation & Better progress in tensile and flexural strengths & {$[38]$} \\
\hline Benzoylation & $\begin{array}{l}\text { Superior in surface modifications and better } \\
\text { improvement in the hydrophobicity }\end{array}$ & {$[38]$} \\
\hline Enzyme & Helps to decrease the lignin content from $35 \%$ to $24 \%$ & {$[38]$} \\
\hline Grafting & $\begin{array}{l}\text { Better enhancement in properties and ultraviolent } \\
\text { protection properties }\end{array}$ & [78] \\
\hline Mercerisation & $\begin{array}{l}\text { Helps to reduce the moisture content and gives a } \\
\text { better interface and significant result in flexural and } \\
\text { tensile strengths. }\end{array}$ & {$[83]$} \\
\hline Methacrylate & Better improvement in tensile and flexural strengths & {$[98]$} \\
\hline Ozone & $\begin{array}{l}\text { Increases the strength properties of polyethylene and } \\
\text { pulp composites }\end{array}$ & {$[100]$} \\
\hline Plasma & $\begin{array}{l}\text { Superior in surface modifications and better } \\
\text { improvement in the hydrophobicity }\end{array}$ & {$[101]$} \\
\hline Silane & $\begin{array}{l}\text { Better improvement in the hydrophobicity and } \\
\text { mechanical properties }\end{array}$ & [102] \\
\hline Sodium chloride & $\begin{array}{l}\text { Significant increase in the properties such as tensile } \\
\text { strength, youngs modulus and extension of the break }\end{array}$ & [103] \\
\hline
\end{tabular}

\subsection{Benefits and challenges of natural fibres over synthetic fibres}

In response to the growing demand for environmentally sustainable materials and to minimise the costs of conventional (e.g. steel, glass, carbon, and aramid), researchers have started to concentrate on NFRPCs. Moreover, natural fibres show many advantages in mechanical properties that facilitate the substitution of synthetic fibres in polymer composite. J. Agarwal et al. [104], stated that natural fibre polymer matrix composite is manufactured either using thermoplastic or thermosetting reinforced polymers. Synthetic thermoplastics with NFRPC such as (polyethylene, polypropylene, and polyamide) along with natural fibres forms partially biodegradable composites that are equal to the used percentage of natural fibres [105]. The fabrication of these composites can withstand temperatures of $170{ }^{\circ} \mathrm{C}$ during long processing time and around $210-220{ }^{\circ} \mathrm{C}$ during the short time. If the temperature is not under control, discolouration, weak interfacial adhesion, and cellulose damage may occur. The properties of composites depend on the synergetic effect within the matrix, and these effects are attained by 
adding suitable coupling agents [106]. Therefore, the coupling agents are modifiers for the matrix, which helps the poor wettability and weak the interfacial bonding. Maleic anhydride grafted polypropylene is the compatibilizer used for polypropylene matrix [107]. Polypropylene possesses low density, less expense, long durability, and recyclability due to which it is used as thermoplastic matric in automobile industries [104]. One the other hand, epoxy, polyester, and vinyl ester are thermosets used in manufacturing the natural fibre reinforced composites. Primarily epoxy was used in high-performance applications to minimise health hazards. Epoxy-reinforced composites were used in crash applications to minimise the damage of the passengers by placing the intended part between bumper and side rail to absorb maximum dynamic energy [107]

Currently, aluminium and steel are now replaced by NFPC, because of lightweight and release less carbon dioxide footprint without compromising passenger safety. Though automobile industries recommended epoxy for its high performance and durability, few disadvantages are associated, for instance, high cost and long curing time. Because of these drawbacks, the vinyl ester is used among the automobile industries. Vinyl ester is made of epoxy and unsaturated carboxylic acid. They have excellent properties, thermal degradation and can be easily treated in a short time. [21]. However, several factors could affect the properties of NFRP composites, such as incompatibility between natural hydrophilic fibres and hydrophobic thermoplastic matrix that makes it undesirable [108]. In such cases, processing techniques and parameters should be selected precisely, as it has significant influence in the composite properties and interfacial characteristics [27]. There are several types of polymers are available in the market, and the common thermoplastic and thermoset polymers are outlined in Tables 5 and 6. 


\section{Table 5}

Properties of the thermoplastic polymer used in natural fibre composite $[105,109,110]$

\begin{tabular}{llllll}
\hline Property & P.P.* & LDPE & HDPE & PS & PLA \\
\hline Density $\left(\mathrm{g} / \mathrm{cm}^{3}\right)$ & $0.899-$ & $0.910-$ & $0.94-0.96$ & $1.04-1.06$ & 1.252 \\
& 0.920 & 0.925 & & & \\
Water absorption-24 h (\%) & $0.01-0.02$ & $<0.015$ & $0.01-0.2$ & $0.03-0.10$ & N/A \\
$\mathrm{T}_{\mathrm{g}}(\mathrm{C})$ & 10 to 23 & 125 & 133 to 100 & $\mathrm{~N} / \mathrm{A}$ & 55 \\
$\mathrm{~T}_{\mathrm{m}}(\mathrm{C})$ & $160-176$ & $105-116$ & $120-140$ & $110-135^{0}$ & 165 \\
$\begin{array}{l}\text { Heat deflection Temp (C) } \\
\text { Coefficient of thermal } \\
\left(\mathrm{mm} / \mathrm{mm} / \mathrm{C} 10^{5}\right)\end{array}$ & $50-63$ & $32-50$ & $43-60$ & Max. 220 & 55 \\
Tensile strength (MPa) & $6.8-13.5$ & 10 & $12-13$ & $6-8$ & N/A \\
Elastic modulus (GPa) & & & & & \\
& $26-41.4$ & $40-78$ & $14.5-38$ & $25-69$ & 59 \\
Elongation (\%) & $0.95-1.77$ & $0.055-$ & $0.4-1.5$ & $4-5$ & 3.5 \\
Izod impact strength $(\mathrm{J} / \mathrm{m})$ & & 0.38 & & & \\
& $15-700$ & $90-800$ & $2.0-130$ & $1-2.5$ & $7 \%$ \\
& $21.4-267$ & $>854$ & $26.7-1068$ & 1.1 & 26
\end{tabular}

Table 6

Properties of the thermoset polymer used in natural fibre composites $[105,110]$

\begin{tabular}{llll}
\hline Property & $\begin{array}{l}\text { Polyester } \\
\text { resin }\end{array}$ & $\begin{array}{l}\text { Vinylester } \\
\text { resin }\end{array}$ & Epoxy \\
\hline Density $\left(\mathrm{g} / \mathrm{cm}^{3}\right)$ & $1.2-1.5$ & $1.2-1.4$ & $1.1-1.4$ \\
Water absorption-24 h @ 20C & $0.1-0.3$ & 0.1 & $0.1-0.4$ \\
Tensile strength (MPa) & $40-90$ & $69-83$ & $35-100$ \\
Elastic modulus (GPa) & $2-4.5$ & $3.1-3.8$ & $3-6$ \\
Elongation (\%) & 2 & $4-7$ & $1-6$ \\
Izod impact strength (J/m) & $0.15-3.2$ & 2.5 & 0.3 \\
Compressive strength (MPa) & $90-250$ & 100 & $100-200$ \\
Cure shrinkage (\%) & $4-8$ & $\mathrm{n} / \mathrm{a}$ & $1-2$
\end{tabular}

\subsection{Can natural fibre replace synthetic fibres?}

Natural fibres are gaining more attention in composite industries, owing to its specific properties and environmental benefits [111]. Despite poor strength in properties, they partially replace synthetic fibres in structural applications for its enhanced characteristics such as specific modulus and elongation at break (Fig. 10.) [112]. The density of natural fibres shown in Table 7 is less than that of glass fibre, resulting in composites called lightweight fibres. Consequently, much scope has been increased for the industrial consumption of NFPC in different manufacturing sectors [113]. Flax, jute, kenaf, hemp and sisal are used for the manufacture of lightweight composites [114-116]. In general, fibres with higher length - to diameter ratio and cellulose content have been achieved superior mechanical properties [117]. Nevertheless, the structural properties of NFRP composites depend mainly on fibre material, 
fibre distribution and fibre-matrix adhesion [27]. $\mathrm{Ku}$ et al. [118] stated that chemical modification would improve the interfacial matrix-fibre bonding, which results in the significance of tensile properties of natural composites. Moreover, Ahmad et al. [119] also observed that an increase in fibre loading would have a significant increase in tensile properties. Natural fibres provide outstanding thermal and acoustic insulation with beneficial properties over traditional fibres for their low density and cellular structure [120].

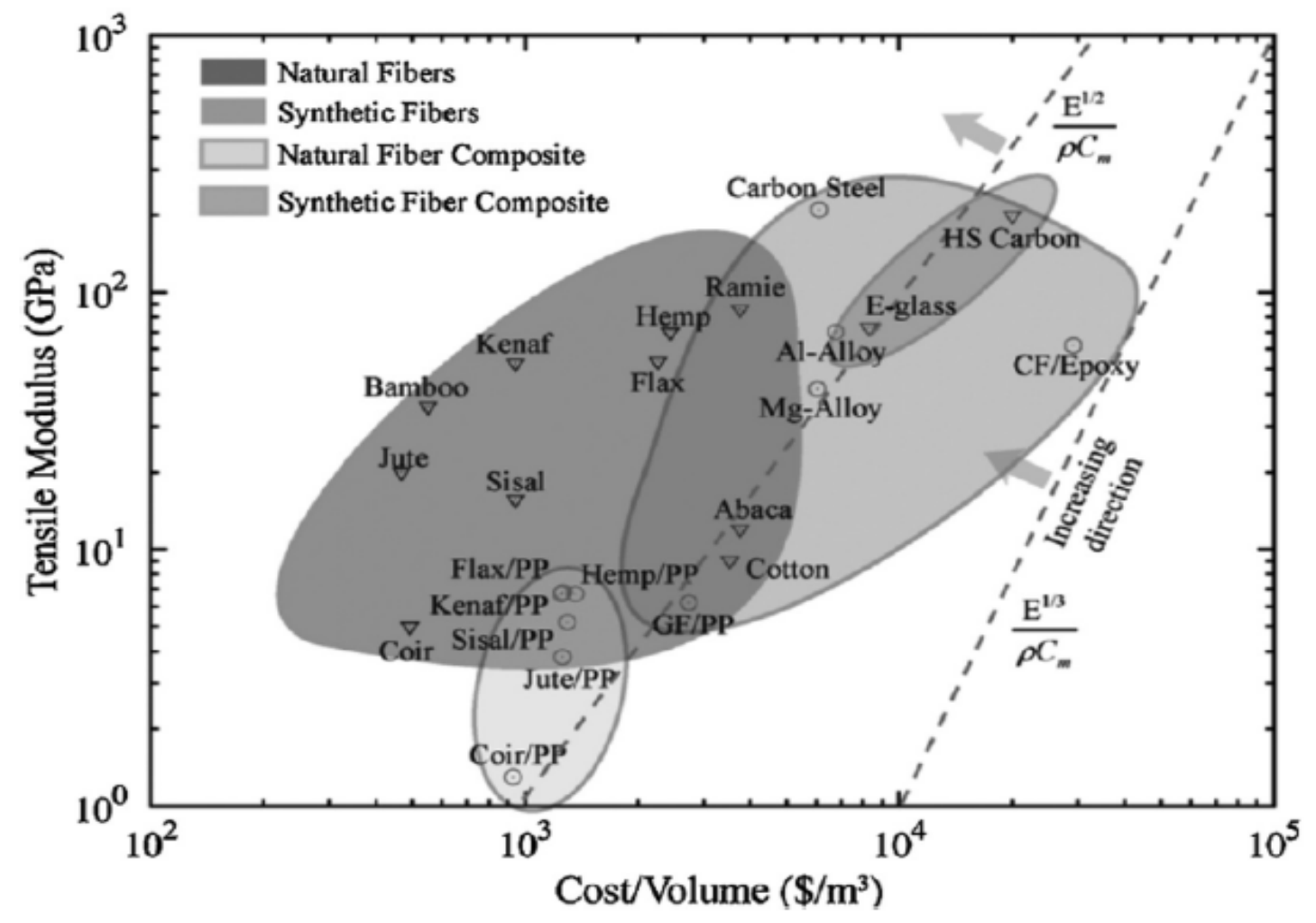

Fig. 10. Tensile modulus versus cost/volume comparison for synthetic and natural fibres [112]. 


\section{Table 7}

Mechanical properties of natural, synthetic and aramid fibres

\begin{tabular}{llllll}
\hline Fibre & $\begin{array}{l}\text { Density } \\
\left(\mathrm{g} / \mathrm{cm}^{3}\right)\end{array}$ & $\begin{array}{l}\text { Elongation } \\
(\%)\end{array}$ & $\begin{array}{l}\text { Tensile strength } \\
(\mathrm{MPa})\end{array}$ & $\begin{array}{l}\text { Elastic modulus } \\
(\mathrm{GPa})\end{array}$ & References \\
\hline Cotton & $1.5-1.6$ & $7.0-8.0$ & 400 & $5.5-12.6$ & {$[105,112,121,122]$} \\
Jute & 1.3 & $1.5-1.8$ & $393-773$ & 26.5 & {$[105,112,121,122]$} \\
Flax & 1.5 & $2.7-3.2$ & $500-1500$ & 27.6 & {$[105,112,121,122]$} \\
Hemp & 1.47 & $2-4$ & 690 & 70 & {$[105,112,121,122]$} \\
Kenaf & 1.45 & 1.6 & 930 & 53 & {$[105,112,121,122]$} \\
Ramie & $\mathrm{N} / \mathrm{A}$ & $3.6-3.8$ & $400-938$ & $61.4-128$ & {$[105,112,121,122]$} \\
Sisal & 1.5 & $2.0-2.5$ & $511-635$ & $9.4-22$ & {$[105,112,121,122]$} \\
Coir & 1.2 & 30 & 593 & $4.0-6.0$ & {$[105,112,121,122]$} \\
E-glass & 2.58 & 4.8 & $3100-3800$ & $80-81$ & {$[123]$} \\
Carbon T-800 & 1.80 & 2.2 & 5516 & 234.5 & {$[124]$} \\
Kevlar 149 & 1.47 & 1.5 & 3400 & 179 & {$[125,126]$} \\
Continuous & 2.66 & 3.56 & 2016 & 61.9 & {$[127]$} \\
Basalt fibre & & & & &
\end{tabular}

\section{Important parameters for measuring the impact toughness of the composite}

In general, composite laminates under fracture toughness usually expressed in critical energy rates (Gc). Based on the loading type, the energy releases the rate at which delaminations actually begins and therefore extends drastically [128]. Fracture toughness Mode I and II governs the impact response of the compact material [18]. As a result, under impact loading, the composite material can absorb a significant amount of energy in the full range of damage modes. [19]. Mode I loading is amongst the most current studies for the delamination fracture type. Many authors [129-131] recommended that ASTM D5528-13 (American Society of Testing Materials), Double Cantilever Beam (DCB) is the standard specimen to measure Mode I fracture toughness $\mathrm{G}_{\mathrm{ic}}$ of the fibre-reinforced composites. The three different methods to calculate the Mode I fracture toughness $\mathrm{G}_{\mathrm{ic}}$ are Modified Beam theory (MBT), Compliance Calibration (CC), and Modified Compliance Calibration (MCC). Among them, the author Caprino, [132] observed that Eq. (2) was better than Eq. (1) and Eq. (3). Similarly, Prasad et al. [133] perceived that the latter method Eq. (2) had yielded $80 \%$ of the repeated values of $\mathrm{G}_{\text {ic }}$ trialled during ASTM round-robin testing. In recent studies, Almansour et al. [134], stated that MBT gives the lowest possible value of the samples related to initiation and propagation. As shown in Fig. 11, the flax fibre of wet samples, $\mathrm{G}_{\mathrm{ic}}$, is comparatively lower than the dry sample. Further, the high absorption of moisture and the water content in the flax fibre makes 
a weak fibre matrix interface and creates surface degradation and reduces fracture strength. Even, Bensadoun et al. [135] found that flax composites showed higher interlaminar fracture strength. Whereas Zulkifli et al.[136], found that multiple fibre layers have a significant impact on the woven silk/epoxy composites toughness.

Delamination often propagates in Mode II under the low-velocity impact [21]. The fracture characterization of such materials can be easily predicted, and propagation is often dominated by a fracture in Mode II [137]. However, it has a few disadvantages, such as unstable crack and predicaments in monitoring crack propagation [137]. Currently, there has been little progress to Mode II [138]. It follows specific delamination methods to test the $\mathrm{G}_{\text {IIC }}$ fracture toughness. Many researchers [21,138] recommended the End- Notch Flexure test (ENF) and End- Load Split test (ELS) as the methods to determine the toughness of the reinforced composite. Due to simplicity, Ferreira De Moura [137] stated that the ENF is the standard method for analysing the Mode II fracture toughness $\mathrm{G}_{\text {IIC. }}$. As per Russell et al. [139], the ENF equation from the simple theory method is given below in Eq. (7).

$$
\begin{aligned}
& G_{i c}=\frac{P^{2} a^{2}}{b c} \\
& G_{i c}=\frac{3 P \delta}{2 b a} \\
& G_{i c}=\frac{9 P I \delta^{4}}{4 b a^{4}} \\
& G=\frac{P^{2}}{2 b} \frac{d c}{d a} \\
& C=\frac{\delta}{P} \\
& C=\frac{2 l^{3}+3 a^{2}}{8 E_{1} b h^{3}}
\end{aligned}
$$

The interlaminar fracture toughness can be obtained by Eqn (4) and (6)

$$
G_{I I C}=\frac{9 P \delta a^{2}}{2 b\left(3 a^{3}+2 l^{3}\right)}
$$

Where $\mathrm{P}$ is the applied load, $\mathrm{b}$ is the delamination length $(\mathrm{mm}), \mathrm{b}$ is the sample width $(\mathrm{mm}), \mathrm{c}$ is the compliance ratio of the load point displacement to the load applied, and $\delta$ is the load point displacement ( $\mathrm{mm})$ 


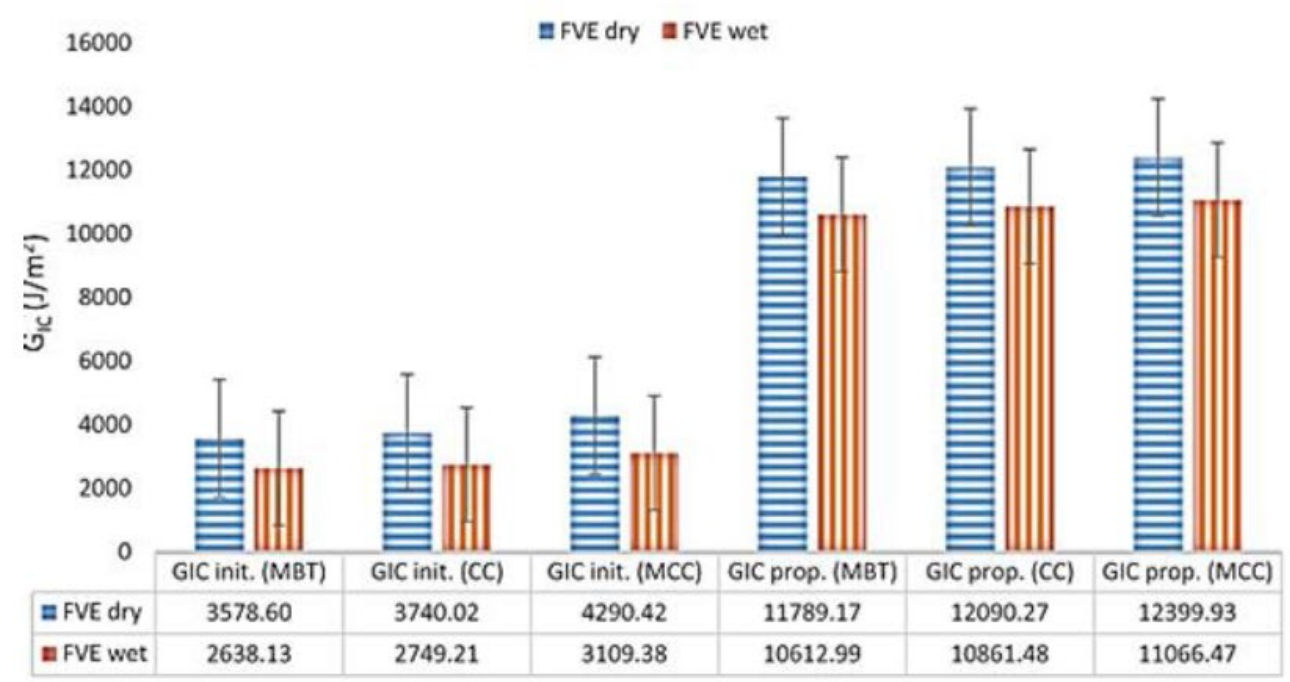

Fig. 11. Initiation and propagation G.I.C. graph against wet and dry flax fibre [134]

Moreover, many researchers are focussing on hybridisation by embedding two or more fibres into one polymer matrix [140]. Composites such as synthetic- synthetic, natural - synthetic, and natural - natural fibre types achieve a possible combination of hybrid composites [141]. Over the past few years, hybrid composites have gained interest in many research areas [142], and it has a vast application in engineering science due to low cost, strength to weight ratio, and ease of manufacturing [143]. However, in contrast to single fibre composites, the hybrid composites possess better fracture toughness, increased fatigue life, and lower notch sensitivity[144]. Furthermore, it has a unique characteristic in mechanical properties and has various advantages over traditional materials, are utilised in many structural or engineering applications[145,146].

\subsection{Hybrid Mode I fracture toughness}

Saidane et al. [147], performed a study on the toughness of hybrid flax and glass-reinforced composites, by using a DCB. They noticed that the hybridisation of flax fibres together with glass fibres during crack propagation $\mathrm{G}_{\mathrm{ic}}$ exhibits a superior interlaminar fracture toughness. However, they found that difference between glass fibres and hybrid fibre reinforcement (HFRE) was closer to the initiation value of $\mathrm{G}_{\mathrm{ic}}$. Moreover, in the propagation stage, the HFRE showed a more considerable value of $\mathrm{G}$ ic in contrast to other composites. Zhang et al. [148] also published the same findings that flax fibre had higher interlaminar shear and fracture toughness compared to glass fibre composites. Jung et al. [149] in their study observed that increased glass fibre could reduce hybrid composite fracture toughness. Also, they found that 
the glass layer tends to withstand/absorb load when the fracture occurred with some carbon fibres.

Almansour et al. [134] experimented the fracture toughness of hybridised flax/basalt reinforced vinyl ester composites. They found that water immersed flax vinyl ester had better performance in the fracture toughness in contrast to dry composites. Besides water immersed flax/basalt stitched improved 15 to $17 \%$ than dry specimens. Moreover, the author Almansour et al. [134], also noticed that basalt hybridisation provides a better shield to the swelled glass fibres. Hybridising basalt as an external layer on flax composites enhances interlaminar fracture toughness. A detailed summary of the toughness of hybrid composites shown in Table 8 .

\section{Table 8}

Outline of Mode I fracture toughness of hybrid composites.

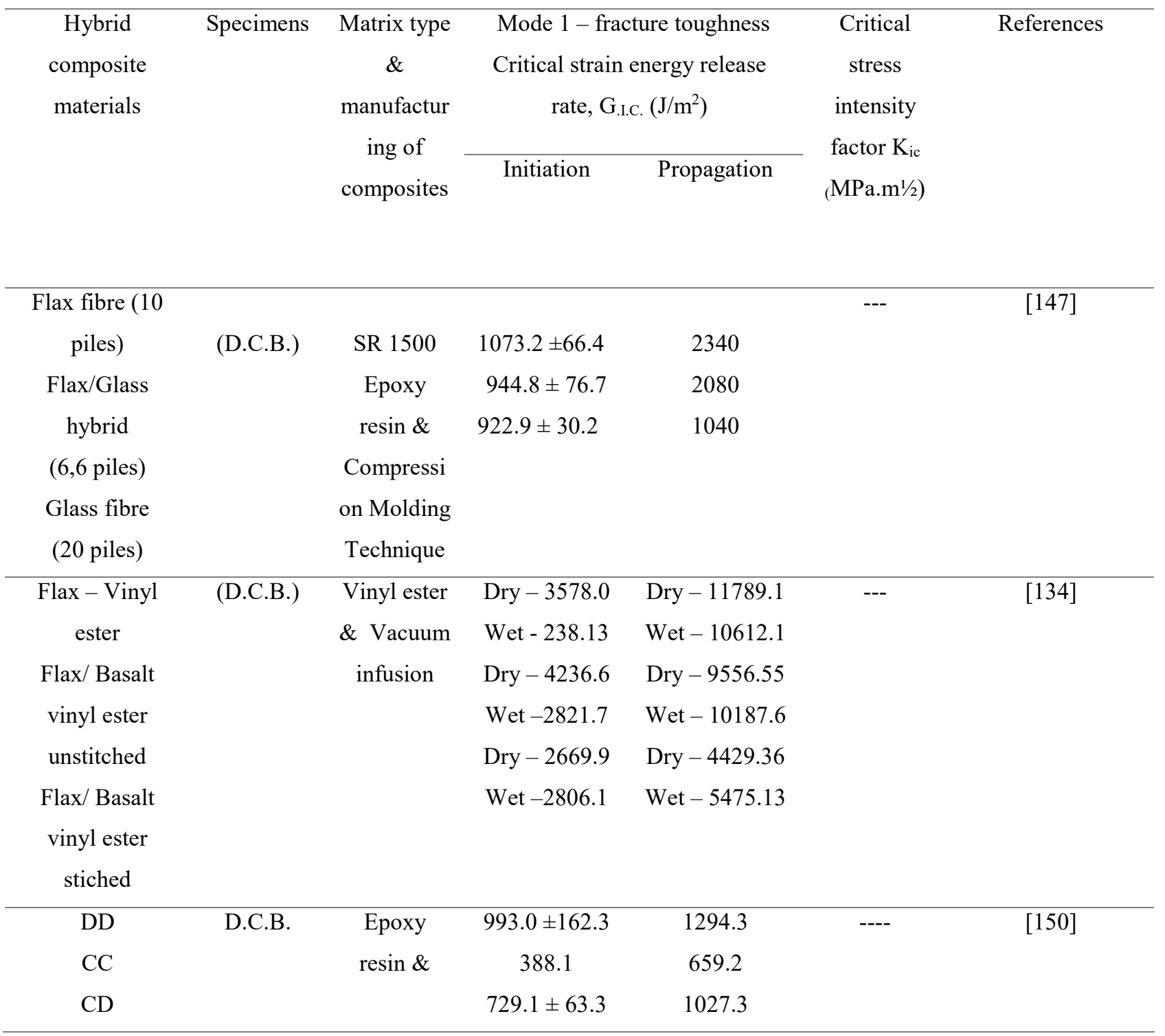




\begin{tabular}{|c|c|c|c|c|c|c|}
\hline $\begin{array}{c}\mathrm{HH}- \\
\text { Interwoven } \\
\text { carbon \& } \\
\text { Dyneema }\end{array}$ & & $\begin{array}{l}\text { Vacuum- } \\
\text { assisted } \\
\text { resin } \\
\text { transfer } \\
\text { moulding }\end{array}$ & $69.1 \pm 62.4$ & 1011.4 & & \\
\hline CGC. & Strain & epoxy resin & --- & --- & 36.457 & [149] \\
\hline (10 Piles) & fracture & $\&$ & & & 32.588 & \\
\hline CGC & toughness & Vacuum- & & & 30.013 & \\
\hline (20 Piles) & test & assisted & & & 30.246 & \\
\hline CGC & & resin & & & & \\
\hline (30 Piles) & & transfer & & & & \\
\hline CGC & & moulding & & & & \\
\hline (40 Piles) & & & & & & \\
\hline
\end{tabular}

\subsection{Hybrid Mode II fracture toughness}

Almansour et al.[151], investigated Mode II fracture toughness on hybridised flax/basalt reinforced vinyl ester composites. They observed basalt fibre hybridised composites performed better interlaminar toughness for initiation and propagation compared to flax vinyl ester dry specimens. Audibert et al. [152], studied the damage mechanism and mechanical characterisation of new flax - kevlar hybridisation composite. They observed that flax and Kevlar fibre shows a stable non - linear anisotropic behaviour. Besides, flax fibre provides better resistance to compressive load compared to kevlar fibre. Kevlar fibre performed better fracture toughness owing to the plastic strain in the non - linearity behaviour. Whereas in flax fibres, the damaged modulus was hugely affected due to the fibre pull-out. Similarly, Salman et al. [153] reported that irregularities in mechanical behaviour caused more damage in the kevlar and kenaf fibres. However, the indication shows that damage occurred in the epoxy resin, particularly in areas where the crack had developed and initiated (Fig. 12). Also, Zhou et al. [154], highlighted that presence of Dyneema fibre improves the fracture toughness of the hybrid composites and delamination growth. A detailed description of Mode II fracture toughness of hybrid reinforced composites shown in Table 9 

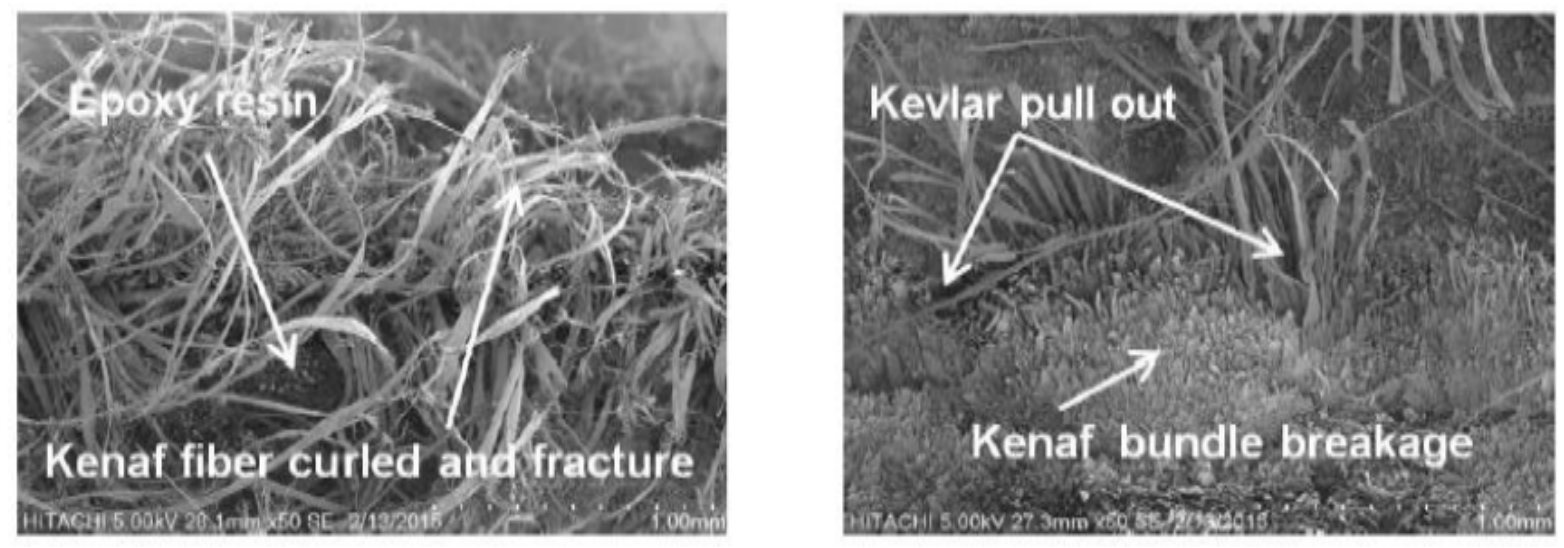

Fig. 12. S.E.M. image of the Kenaf/Kevlar caused by fibre pull-out and fibre breakage [153]

\section{Table 9}

Outline of Mode II fracture toughness of hybrid composites.

\begin{tabular}{|c|c|c|c|c|c|c|}
\hline \multirow[t]{2}{*}{$\begin{array}{c}\text { Hybrid composite } \\
\text { materials }\end{array}$} & \multirow[t]{2}{*}{$\begin{array}{l}\text { Specim } \\
\text { ens }\end{array}$} & \multirow{2}{*}{$\begin{array}{l}\text { Matrix type } \\
\& \\
\text { manufacturin } \\
\text { g of } \\
\text { composites }\end{array}$} & \multicolumn{2}{|c|}{$\begin{array}{l}\text { Mode } 1 \mathrm{I} \text { - fracture toughness } \\
\text { Critical strain energy release } \\
\text { rate, G.I.c. }\left(\mathrm{J} / \mathrm{m}^{2}\right)\end{array}$} & \multirow{2}{*}{$\begin{array}{c}\text { Critical } \\
\text { stress } \\
\text { intensity } \\
\text { factor } \mathrm{K}_{\mathrm{ic}} \\
\left(\mathrm{MPa} \mathrm{m}^{1} \mathrm{2}\right)\end{array}$} & \multirow[t]{2}{*}{ References } \\
\hline & & & $\begin{array}{c}\text { Initiation } \\
\text { SBT }\end{array}$ & $\begin{array}{c}\text { Propagation } \\
\text { S.B.T. }\end{array}$ & & \\
\hline FVE dry & & Vinyl ester & 239.85 & 3648.82 & -- & [151] \\
\hline FVE wet & $3 \mathrm{ENF}$ & \& Vacuum- & 328.32 & 5039.4 & & \\
\hline FBVEs dry & & assisted & 615.29 & 2779.02 & & \\
\hline FBVEs wet & & transfer & 685.75 & 3577.82 & & \\
\hline FBVEu dry & & moulding & 369.54 & 4498.74 & & \\
\hline \multicolumn{7}{|l|}{ FBVEu wet } \\
\hline Flax -epoxy & $3 \mathrm{ENF}$ & Epoxy resin & --- & --- & $2.5 \%$ & [152] \\
\hline Kevlar-epoxy & & \& Vacuum & & & $1.6 \%\}$ & \\
\hline \multirow{3}{*}{$\begin{array}{l}\text { Kevlar/flax - } \\
\text { epoxy }\end{array}$} & & infusion & & & Tensile & \\
\hline & & process & & & Elongation & \\
\hline & & & & & fail & \\
\hline $\mathrm{Cc}$ & $3 \mathrm{ENF}$ & Epoxy resin & --- & 2128 & -- & [154] \\
\hline $\mathrm{CD}$ & & $\&$ Vacuum & & 3499 & & \\
\hline $\mathrm{HH}$ & & assisted resin & & 3192 & & \\
\hline \multirow[t]{3}{*}{$\mathrm{DD}$} & & transfer & & 4458 & & \\
\hline & & moulding & & & & \\
\hline & & (VARTM) & & & & \\
\hline
\end{tabular}




\section{Factors affecting the impact response of natural fibre composites}

The critical factor that affects the impact characteristics are material characteristics, geometrical factors, impactor shape/size and environmental service conditions (Fig. 13.).
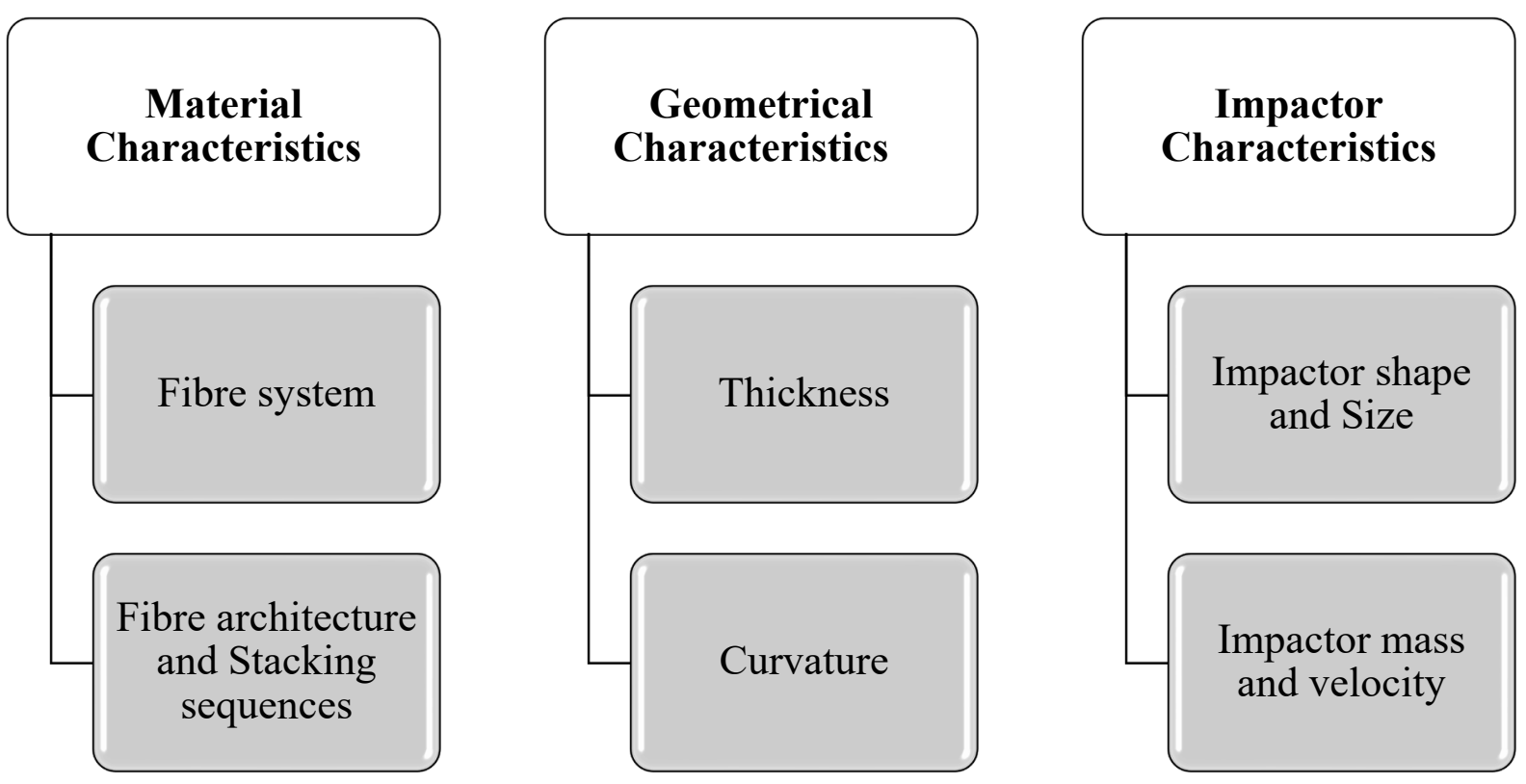

Fig. 13. Factors affecting the impact response of natural fibre composites modified from Andrew et al. [15]

\subsection{Material characteristics}

\subsubsection{Natural fibre system}

The nature of the fibre system relies on the fibre reinforcement, which provides crucial loadbearing elements offering structure with greater strength and rigidity [155]. The impact properties are influenced by the size used, their distribution, fibre volume percentage and volume portion orientation within the matrix [156]. Bar et al. [157], studied the mechanical properties of flax-polypropylene reinforced composites and observed that impact strength decreases with higher flax content. Similar results obtained by George et al.[158], for the flax fibre-reinforced epoxy composites, where the tensile strength and modulus increase with fibre loading. On top that by adding 35 Vol.-\% fibre, the tensile strength was noted to increase to $20 \%$ compared to the neat epoxy system, but the strain to failure rate was decreased due to fibre content. Nevertheless, three reinforcements can be accomplished by aligning the fibrefilled composites, orientation and position of fibres within a matrix (i) longitudinally - could 
obtain high tensile strength and low compression strength by the buckling of fibres transversely - could achieve low tensile strength and (iii) short fibre randomly oriented challenging to predict the mechanical properties, due to the weak distribution of load [159161]. Therefore, Shesan et al. [156] stated that high-performance NFPCs could generally be obtained primarily by using materials with high fibre content, and hence fibre loading on NPCs is essential. Moreover, the additional fibre content of the composites inevitably leads to increased tensile properties $[162,163]$.

\subsubsection{Natural fibre architecture and stacking sequences}

Restricting plant fibre composites to the large volume and structural elements is due to the restricted information about how these materials fail under bi-directional impact loading [164]. In general, the plant fibre architecture on impact behaviour is uncertain, and still, it is unstated. Moreover, alternative considerations on the existence of 3-D fibres on impact properties have always opposed the usage of plant fibre mats for application purposes [165]. In addition, inserting loose plant fibres into the composite by applying adequate pressure will allow a higher amount of reinforcement in the composite. Santulli C et al. [164] investigated the falling weight impact properties on different types of Hemp/ epoxy composites; one is unidirectional $\left(0 / 90^{\circ}\right)$ hemp fibres and hemp mat (M laminate). They observed the unidirectional laminate gives the better performance in the Quasi-static results. Though, they noticed that mat fibre laminates absorbed significant energy during the impact event. However, in the hysteresis cycle, hemp mat fibre may have an improved impact resistance followed by a barely noticeable drop in load and considerable rebound energy released at quasi-constant rate after penetration. Similar observation also made by Dhakal et al. [166], observed that fibre volume fraction of hemp/polyethene composite had a better energy absorption in the unidirectional laminate since the impact resistance was highly dependent on the hemp layers. According to Bensadoun et al., unidirectional fibre architecture has a significant impact on the damage resistance, whereas, in energy absorption, the results were not significant [167]. However, interwoven fibre architecture is also helpful in minimising the escalation of fibre damage and increasing laminate tolerance [168]. Awais et al. [168] fabricated hemp, jute and flax fibres with woven composites (W.C.), woven commingled composites (WCC) and knitted commingled

composites (KCC) (Fig. 14.) and observed that WC laminates (refer Fig. 15.) performed excellent impact resistance than the others. Besides, woven composite laminates (W.C.) showed the lowest energy absorption. Lebaupin et al. [169] investigated the impact resistance and stacking sequence of the flax/polyamide composites. Unidirectional $\left(0^{\circ}\right)_{8}$, cross-ply 
$\left(0^{\circ} / 90^{\circ}\right)_{2 \mathrm{~s}}$, sandwich-like $\left(02^{\circ} / 90_{2}{ }^{\circ}\right)_{\mathrm{s}}$ and quasi-isotropic $\left(45^{\circ} / 0^{\circ}-45^{\circ} / 90^{\circ}\right)_{\mathrm{s}}$ were fabricated. They observed that cross-ply and quasi-isotropic samples had less damage visible in front sides, refer Fig. 16 (b) and (d). Also, they noticed that unidirectional and sandwich layups absorbed higher impact energy than other configurations - moreover, Muralidhar et al.[170] stated that the increase of flax/epoxy composite preformed layers leads to the decline of the absorbed energy. Simultaneously, the layup angle seems to affect the impact properties of the preformed composite. Even, Kannan et al. [171] also noticed that the energy absorption of the flax/ polypropylene composite was highly dependent on the composite's fibre orientation.

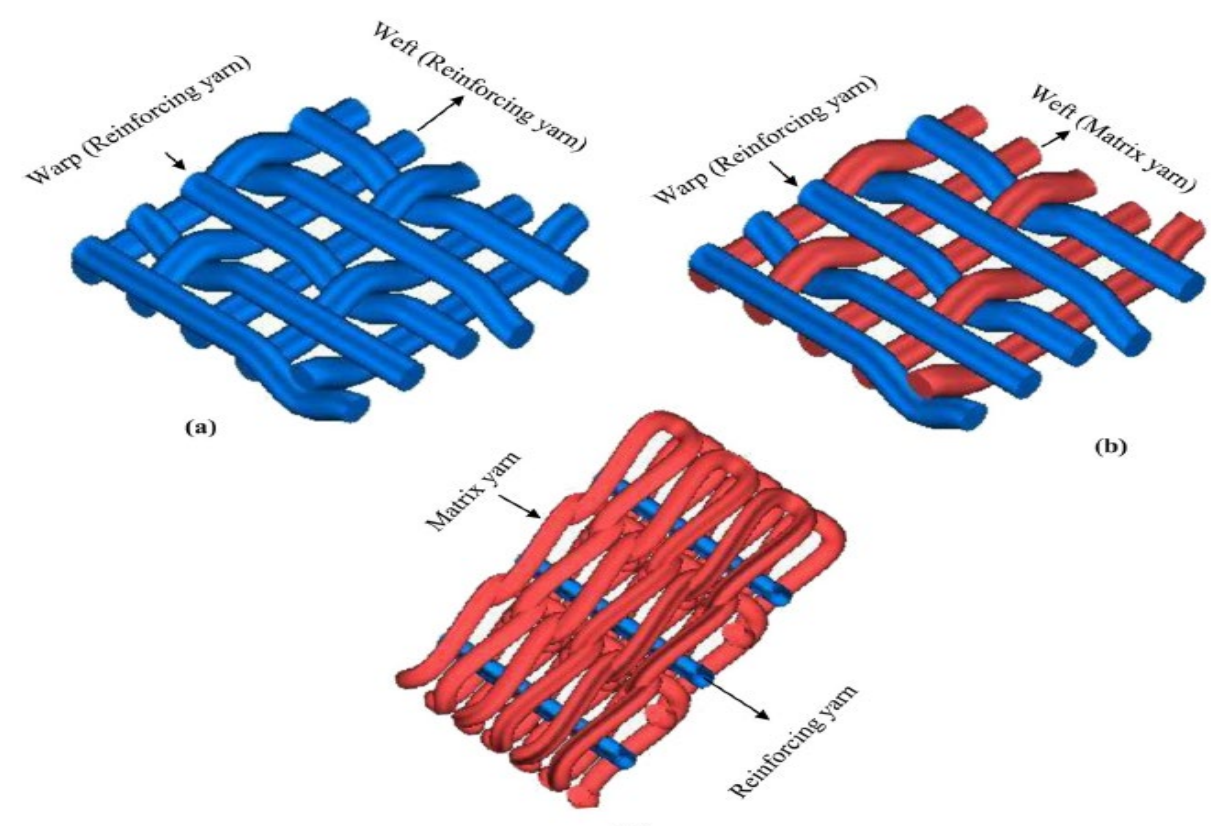

(c)

Fig. 14. Graphical representation of fabric preforms (a) woven, (b) woven commingled, and (c) knitted commingled [168].

Woven matrix preforms (PP)

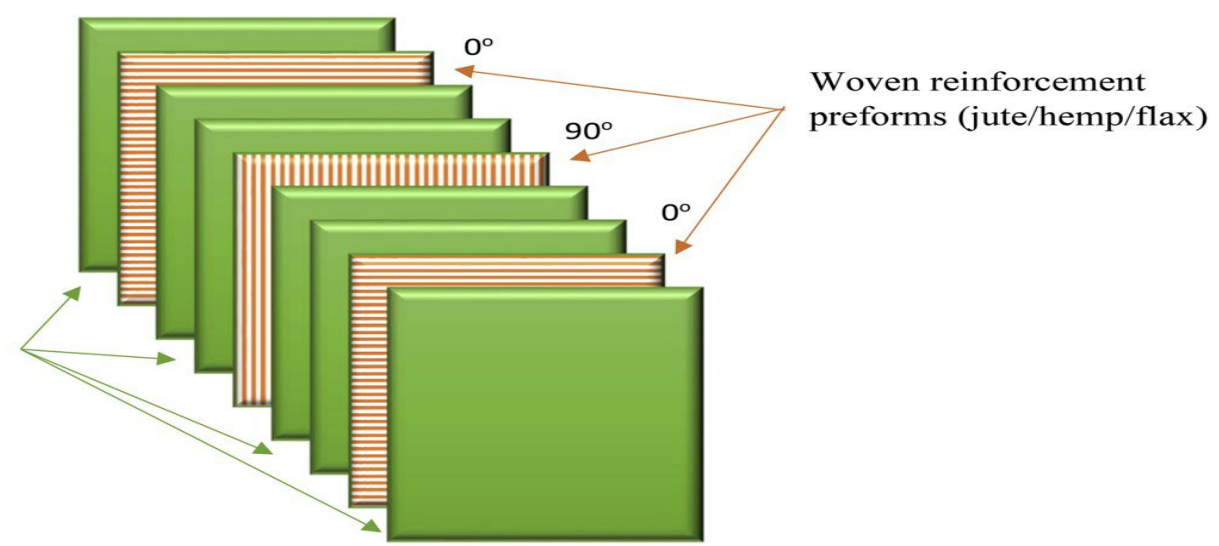

Fig. 15 Stacking sequence of woven composite (W.C.) laminates [168]. 


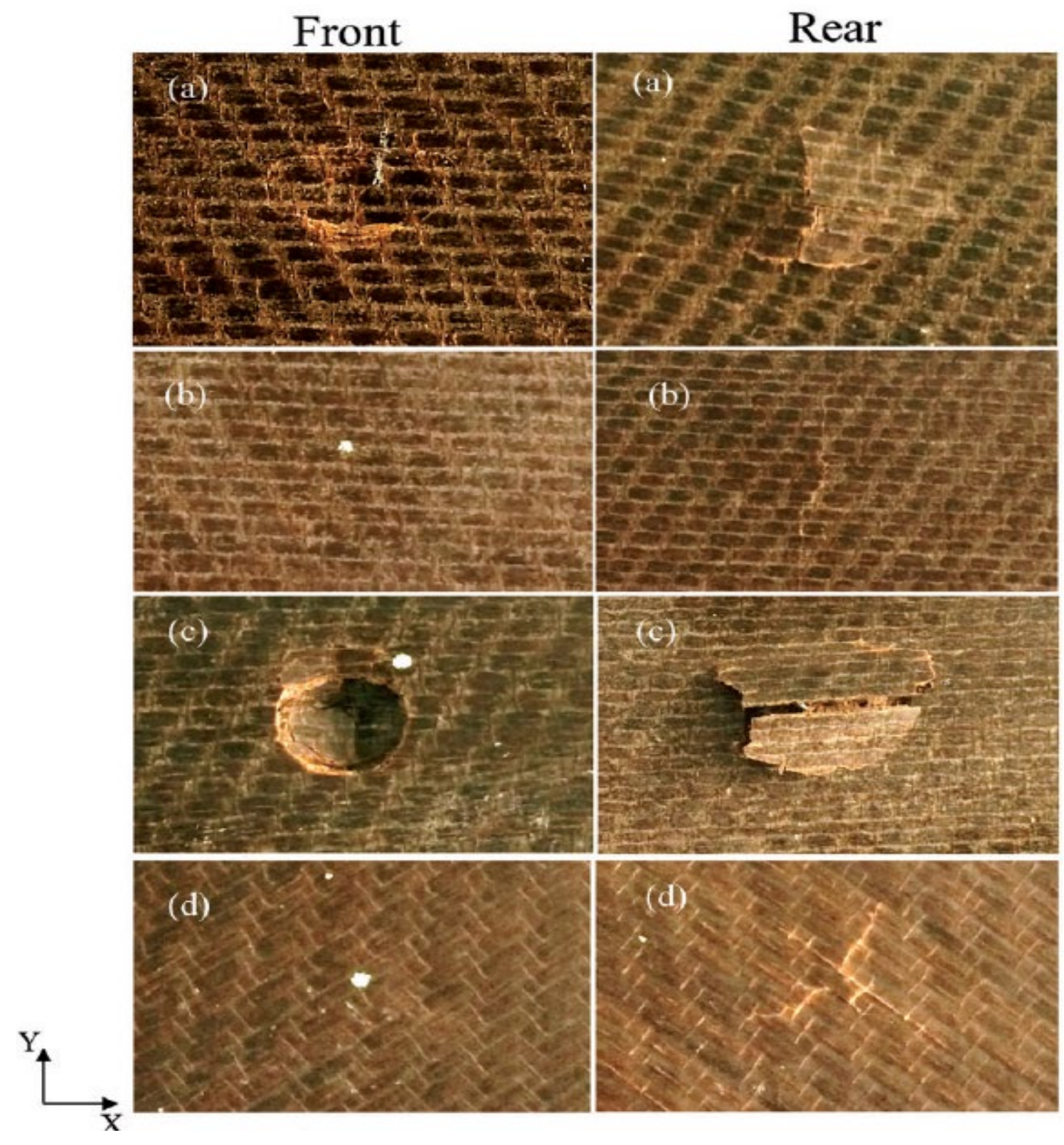

Fig. 16 Damage images on the front and rear faces of (a) unidirectional, (b) cross-ply, (c) sandwich-like and (d) quasi-isotropic composites impacted at 3.6 J. [169]

\subsection{Geometrical characteristics}

\subsubsection{Thickness}

Thickness is the essential parameter because it modifies the energy absorption mode and the area of composite failure. The predominant failures were determined during the impact event, mainly by the composite laminate thickness [172]. Therefore by considering thickness in NFPC composites, Wang et al. [173], noticed that impact force and the Hertzian force of flax - fibre reinforced polymer was found to increase with increasing thickness. Whereas the ductility index decreases with increased composite thickness. Dhakal et al.[174] stated that the thickness 
is essential in the behaviour of jute (methacrylated soybean oil) MSO bio-composites in lowspeed impacts. However, the connection between impact response and damage profile against laminate thickness was not adequately recognized. Zaman et al. [175] studied the influence of fibre volume fraction on coconut fibre reinforced composites. They observed that increasing $15 \%$ of fibre content leads the composites more flexible and easy to deform; in fact, it could be used to reduce the high resonant effect. A similar observation made by Singleton et al. [176] on high-density polyethylene composites with flax and concluded that better impact strength is found at $10 \%-20 \%$ of fibre content. Garkhail et al. [177] observed Charpy tests on flax fibre length ranging from 5, and $10 \mathrm{~mm}$ yielded the highest impact strength in flax/polypropylene composites. Bax and Mu“ssig [178] noticed the impact resistance of flax fibre/polylactic acid increases with the fibre mass fraction.

\subsubsection{Curvature}

Curvature has a significant influence on the NFPC with the response to impact loads, due to high shear stress induced by the extrusion or injection moulding process, the fibre can easily bend into the composite. However, it is rational to think that micromechanical models require a factor of adjustment that considers the natural fibre curvature to estimate the better mechanical properties of the composite [179]. Though the reports in the literature consider other contributing factors, these findings do not comply with the experimental values [180183]. Saghafi et al. [184], analysed the preload effect of the impact behaviour of the curved composite panels by placing samples under tensile and compressive stress. Their findings exhibit that the preload of the plate had a significant influence on the impact factors like final displacement and damage. Over the past two decades, several studies have studied the effect of curvature on the impact behaviour of composite, but attention is focused primarily on lowspeed impact tests [15]. Laminates with higher curvatures showed lower deflection and higher contact strength constantly than a flat plate. The impact behaviour of curved composite plates yet to be explored experimentally. Invoking these experimental experiments will provide ample practical and reliable details on complicated damage mechanisms of curved composites.

\subsection{Impactor characteristics}

Impactor characteristics were widely examined for the study of impact mechanics of composites, including shape, size speed, mass and angle. Fig. 17. signifies several forms of the impactor and different pattern of perforation in the target lamina by different projectiles, respectively. Lee et al. [185] performed a low-velocity impact test on four different impactors: 
flat, hemispherical, semi-cylinder, and conical on sheet moulding laminates. They noticed that flat and hemispherical impactor exhibited similar damage and energy dissipation levels. Zhou et al. [186] noticed that the impactor shape influences the failure mechanism of laminates under low-velocity impact tests. Mines et al. [187] performed a high-velocity test with flat and hemispherical conical impactors. They observed that flat and hemispherical impactors generated higher delamination compared to the rest. Dhakal et al. [7] studied the effect of varying impactor geometries, where they observed that different impactor shapes would produce various failure mechanisms and the damage areas in the composite structures; thus, the residual material will differ upon the impactor shape. Ambur \& Kemmerly [188] performed the impact test on woven composite plates for investigating the effect of impactor mass for forty-eight piles of laminated composites at four different masses ranging from 1.1 to $9 \mathrm{~kg}$. They noticed that there is no change on impactor mass for the impact range investigated from 10-33 J. Bucinell et al. [189], observed that even with increasing mass ratio from highest to lowest up to 5, there would be no changed on the mass impactor.

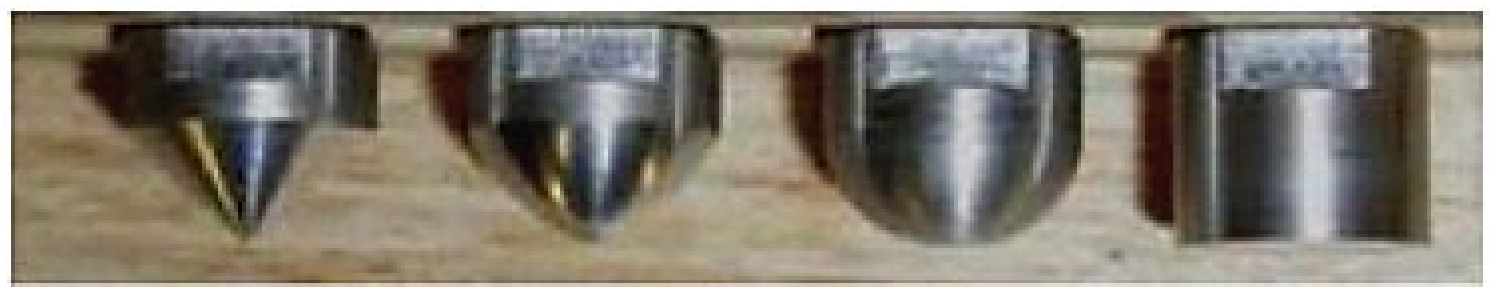

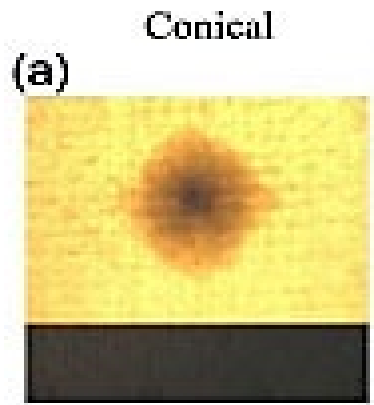

(e)

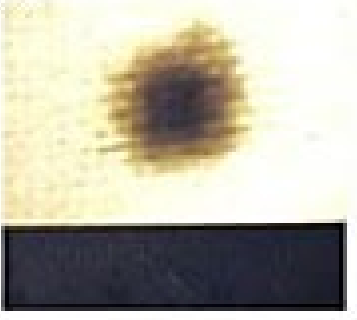

(b)

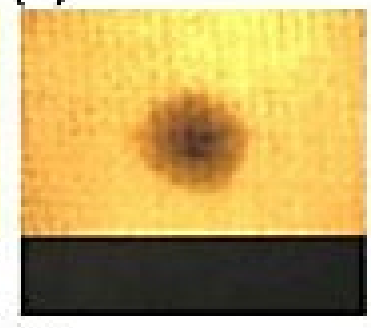

(f)

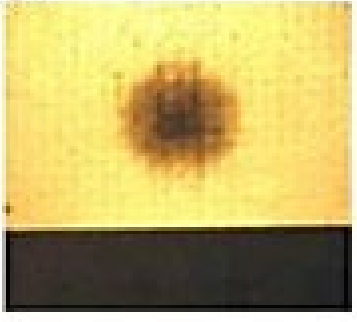

(c)

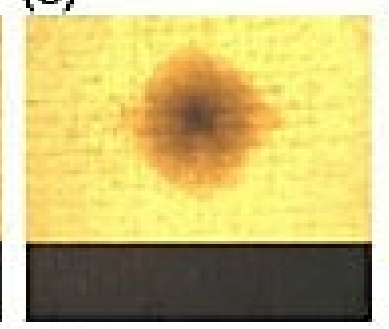

(g)

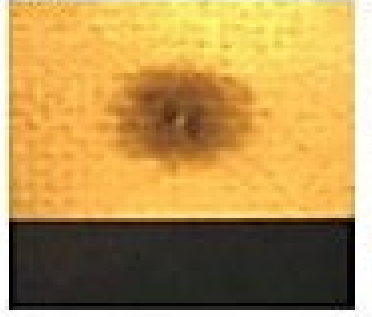

Flat

(d)

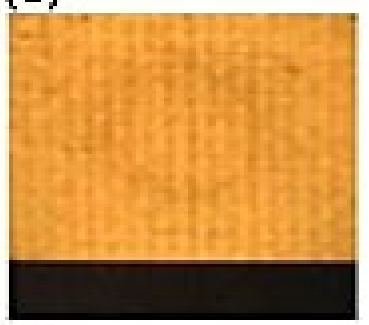

(h)

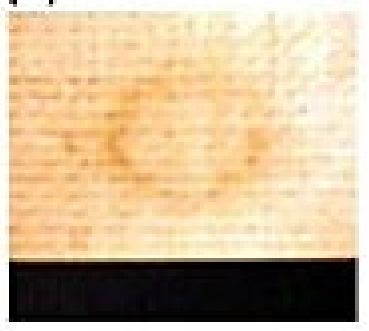

Fig. 17. Result of impactor size and type on the resulting damage to composite laminates [190]. 


\section{Properties of natural fibre in terms of impact damage characteristics}

Couture et al. [191], Investigated the mechanical properties of flax and polylactic acid. Tensile, flexural, and impact tests were observed during the process. The compression moulding fabrication technique was used to impregnate U.D. reinforcement. During the tests, the tensile strength of the UD - Flax/PLA showed a higher value than U.D. flax-paper/PLA. The maximum tensile strength for UD Flax/PLA was $(339 \pm 23 / 62 \pm 1.4 \mathrm{MPa})$ by a factor of 5.5 and for U.D. flax-paper/P.L.A. (316 $\pm 14 / 62 \pm 1.4 \mathrm{MPa})$ by a factor of 5.1. Sathish et al. [192], examined the properties of flax fibre-reinforced epoxy composites with the influence of $\mathrm{SiC}$ and $\mathrm{A} 12 \mathrm{O} 3$. The obtained tensile, flexural and impact strength were $44.56 \mathrm{MPa}, 112.56 \mathrm{MPa}$ and $28.57 \mathrm{KJ} / \mathrm{m} 2$ at $20 \%$ weight of flax fibre and $8 \%$ weight of SiC. However, these results have a vital influence on the mechanical properties of flax composites.

Sair et al. [193], studied the rigid polyurethane and hemp fibre at different loading rates $(5 \%$, $10 \%, 15 \%, 25 \%, 30 \%$ ) to determine the mechanical properties and thermal conductivity. The result showed that composite with $15 \%$ wt fibre loading provided a $40 \%$ increase in tensile strength, and also thermal conductivity increased linearly with density. Haghighatnia et al.[194] studied on the fibre length, fibre content, and alkali treatment of $40 \%$ hemp fibre and thermoplastic - polyurethane composite. They noticed that the hemp fibre content in composite increases in flexural and tensile strength with an increase in modulus. The tensile properties of hemp composite are better than pure thermoplastic polyurethane. Lu \& Oza [195], compared the mechanism of hemp fibre with virgin and recycled high-density polyethylene matrix. Composites were prepared using recycled high-density polyethylene (rHDPE) and virgin highdensity polyethylene (vHDPE). Before the fabrication, the hemp fibres were treated with 5 $\%$ wt of $\mathrm{NaOH}$. The indication of $5 \%$ wt $\mathrm{NaOH}$ treatment significantly improved the fibrematrix interface resulting in improved mechanical properties. Neves et al. [196], studied the mechanical properties of epoxy and polyester composite reinforced by hemp fibre. The fibre content of 10,20, and $30 \mathrm{vol} \%$ of continuous and aligned fibres were mixed with either epoxy or polyester composites. The result showed that for a higher amount of $30 \mathrm{vol} \%$ of fibre content along with epoxy composite gives a superior strength than polyester composite. The flexural and tensile strength of epoxy composites reinforced with hemp fibre is $76 \mathrm{MPa}$, and $50.5 \mathrm{MPa}$ are higher than 49.1 and $25.4 \mathrm{MPa}$ respectively for polyester composites. The author Neves et al. [196] recommended hemp fibre/epoxy composite as an essential application for multilayer armour ballistic protection system. 
Akhtar et al. [197], investigated alkaline treatment and the properties of untreated and treated kenaf/polypropylene reinforced composites. By using an injection moulding technique, the result appeared that the alkaline treated kenaf/PP composites performed better in tensile, modulus, and flexural strength than the untreated kenaf/PP composites. The author Akhtar et al. [197], also observed that $40 \%$ of fibre loading had a significant increase in tensile strength which is beneficial in automotive applications. Abu Bakar et al. [198] observed kenaf fibres weighing $5,10,1520$, and $25 \%$ in the hot-pressed method with $4 \%$ of $\mathrm{NaOH}$ and they reported that the highest flexural strength and modulus improved by almost $24 \%$ and $83 \%$, at $25 \%$ wt of treated fibre loading. While with the epoxy composites, treated fibres yield better results than untreated with the help fibre-resin bond, which is enhanced by $\mathrm{NaOH}$.

\section{Natural fibre composites and their hybrids: benefits and critical issues}

Natural fibres are hydrophilic because their hydroxyl groups swell in water, leading to inappropriate characteristics. However, the combination with synthetic hydrophobic fibres ensures the absorption is minimised and hence improving the material properties $[120,199]$. Basalt fibres have also recently been considered to be an appropriate substitute for glass fibres [200]. Since they have a lower environmental impact, they can compete effectively with glass in sectors such as automotive, for instance, improved acid resistance [201]. Nisini et al. [200] observed that basalt layers reduce the bending of flax fibre laminates and improve their rigidity, which is advantageous for flexural and interlaminar strength. Besides, other configuration was not significantly increased. Fragassa et al. [202] noticed that the reduction in the brittleness of basalt fibre provides some evidence of plastic behaviour, in particular, the hybridization with flax fibre reinforced composites provides a relatively long period of quasi-constant load during the impact tests. Thus lead to delayed failure time, while extensive damage is caused. Petrucci et al. [203] studied the impact characteristics of hemp, basalt, glass and flax hybrid composites. They noticed that GHB. (Glass, Hemp and Basalt) achieved the worst impact performance compared to FHB. (Flax, Hemp and Basalt) hybrid composites. Akhil et al. [204] observed that glass fibre hybridised with the jute fibre reinforced composites reduces the absorption and improves the tensile and flexural properties. Similar findings have been reported in other literature studies [205,206]. Currently, researchers are focussing on natural-natural fibres reinforced hybrid composites as appropriate alternatives to carbon and glass Fibres [202,207209]. Natural fibres may also be combined with other natural fibres and incorporated into a polymer matrix to create a hybrid composite. This can balance the costs, boost the material's efficiency and properties [210]. Cavalcanti et al. [211] investigated hybridisation and chemical 
treatments of Jute, sisal and curaua fibres. They noticed that the hybridisation process enhanced the properties of pure jute fibre composite treatments, which also influenced impact strength. Compared to flexural tests, alkaline treatment increased the impact strength of jute + sisal, while the treatment damaged jute+curaua hybrid composites. Similarly, there are numerous researches on hybrid composites enhanced with natural fibres (e. g. sisal, jute, curaua, ramie, banana leaf) or natural fibres combined with glass fibres [27,212-226].

\subsection{Damage mechanisms of natural fibre composites and their hybrids under impact loadings}

Understanding of composite material damage mechanisms involves accurate mapping of failure actions using reliable technology. This study of literature analysis the low and high velocity falling weight impact damage behaviour of hybrid composites. Papa et al. [227] investigated a low-velocity impact behaviour on carbon/glass hybrid composites laminates by using a cylindrical impactor with a $19.8 \mathrm{~mm}$ diameter hemispherical nose. They observed that stacking of 10 glass and 50 carbon layers with glass on the impacted side showed the highest load of $4713.26 \mathrm{~N}$ with the least absorbed energy of $6.20 \mathrm{~J}$. However, similar results also observed by Zhang et al. [228] for a low-velocity impact behaviour of carbon- glass hybrid composite by drop-weight impact test. They noticed that 1.1 (CG) and 1.4 (CGGC) of hybrid ratio achieved higher peak force with less absorbed energy. Also, Chen et al. [229] studied the hybridisation effect and fabric structure of carbon/basalt/glass-reinforced plastic composites. Low-velocity impact behaviour was performed under the energy levels of $50 \mathrm{~J}$ and $60 \mathrm{~J}$, respectively. The stacking sequence of 16 piles of unidirectional or plain weave fabric showed a considerable effect on the impact resistance. However, on the hybridisation of three different fibres, the placement of carbon layers achieved higher energy absorption compared to the same stacking configuration by hybridising with carbon, glass, or ballast fibres. Tirillò et al. [230] performed a high-velocity impact test on hybrid basalt- carbon epoxy composites. Four different stacking sequences were impacted by a spherical tempered steel projectile of mass $1.725 \mathrm{~g}$ and diameter $7.5 \mathrm{~mm}$ with the impact velocity ranging from $165-475 \mathrm{~m} / \mathrm{sec}$ were used and performed using a gas gun. They reported that BCBI ( Basalt Carbon Basalt Intercalated) sandwich configurations performed an excellent combination of impact properties and static properties. However, the Basalt limits are comparatively higher even though the flexural strength and stiffness are the same as C laminates.

Concerning Natural fibre hybridisation, Papa et al. [231] presented an impacted behaviour on basalt/flax hybrid composites with twill laminates. They stated that flax fibre exhibits an 
excellent solution as an impact absorber by reducing the peak stress and absorbing energy by an inelastic modulated response. In contrast, hybridisation with basalt and flax (refer Fig. 18) were efficient than other laminates in short recurring impacts and reducing cumulative failures. Even, Ismail et al. [232] performed a low-velocity impact behaviour of kenaf/carbon hybrid composites with various weight ratios. They reported that $75 \%$ of glass fibres and $25 \%$ of kenaf fibres could withstand impact energy up to 40J. Barouni \& Dhakal [11] investigated a damage assessment in flax/glass hybrid composite plates reinforced with vinyl ester composites. Lowvelocity tests performed for the specimens subjected to the energy level of $25 \mathrm{~J}$ and $50 \mathrm{~J}$ to examine the damage perforation and complete penetration. They observed that in Fig. 19. flax specimens exhibit higher energy absorption during the impact event. Simultaneously, they showed a more significant damage extension at lower energy levels compared to the glass- flax specimen. Bar et al. [233] compared low-velocity impact behaviour on flax-polypropylene hybrid woven composites with plain woven glass fabric reinforced P.P. composites. Resulted that glass P.P. exhibits higher energy absorption with a maximum peak load than flax-based P.P. composites. A detailed summary of the impact tests illustrated in Table 10.

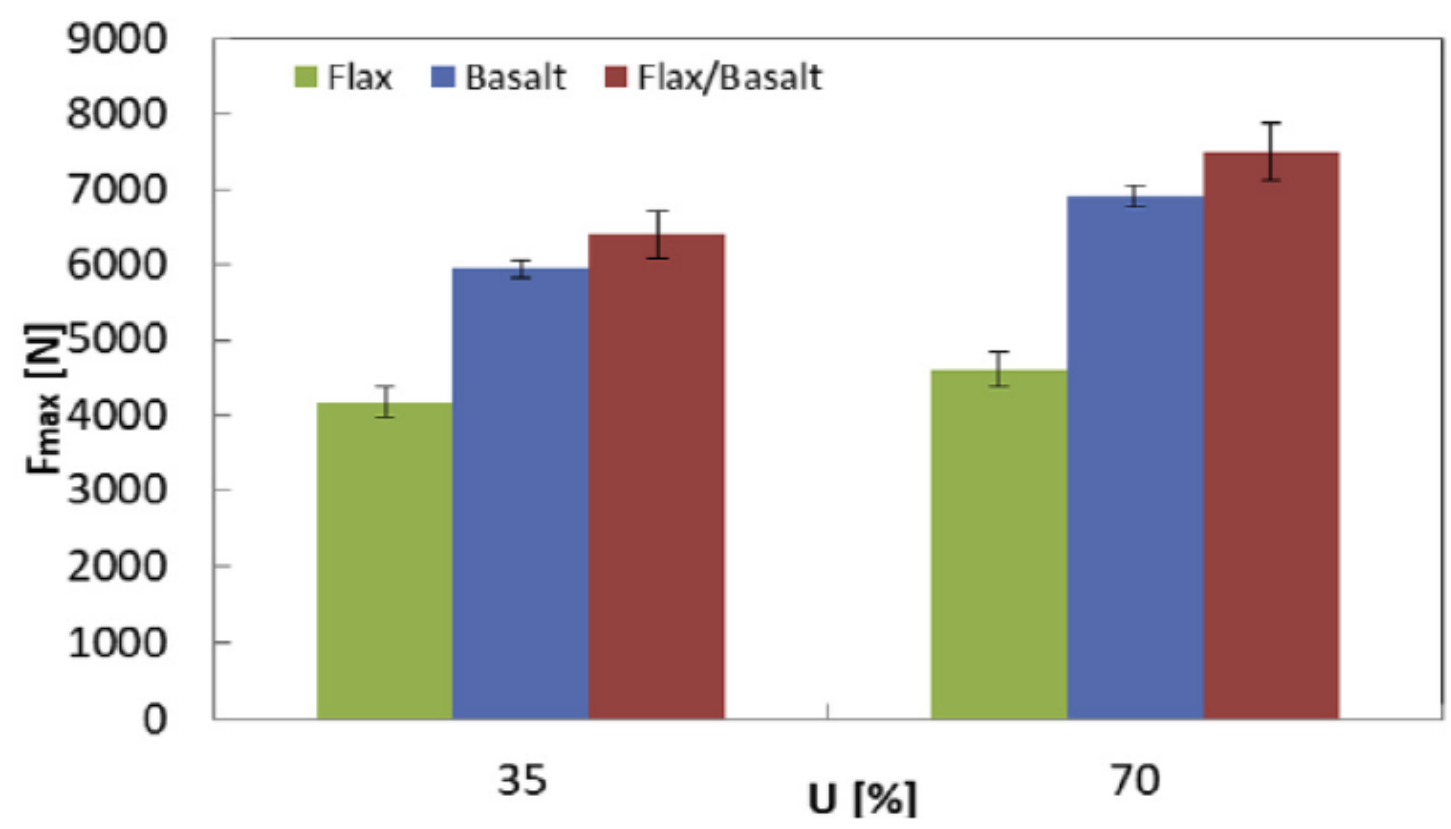

Fig. 18. Maximum load, Fmax, vs impact energy, U. [231] 


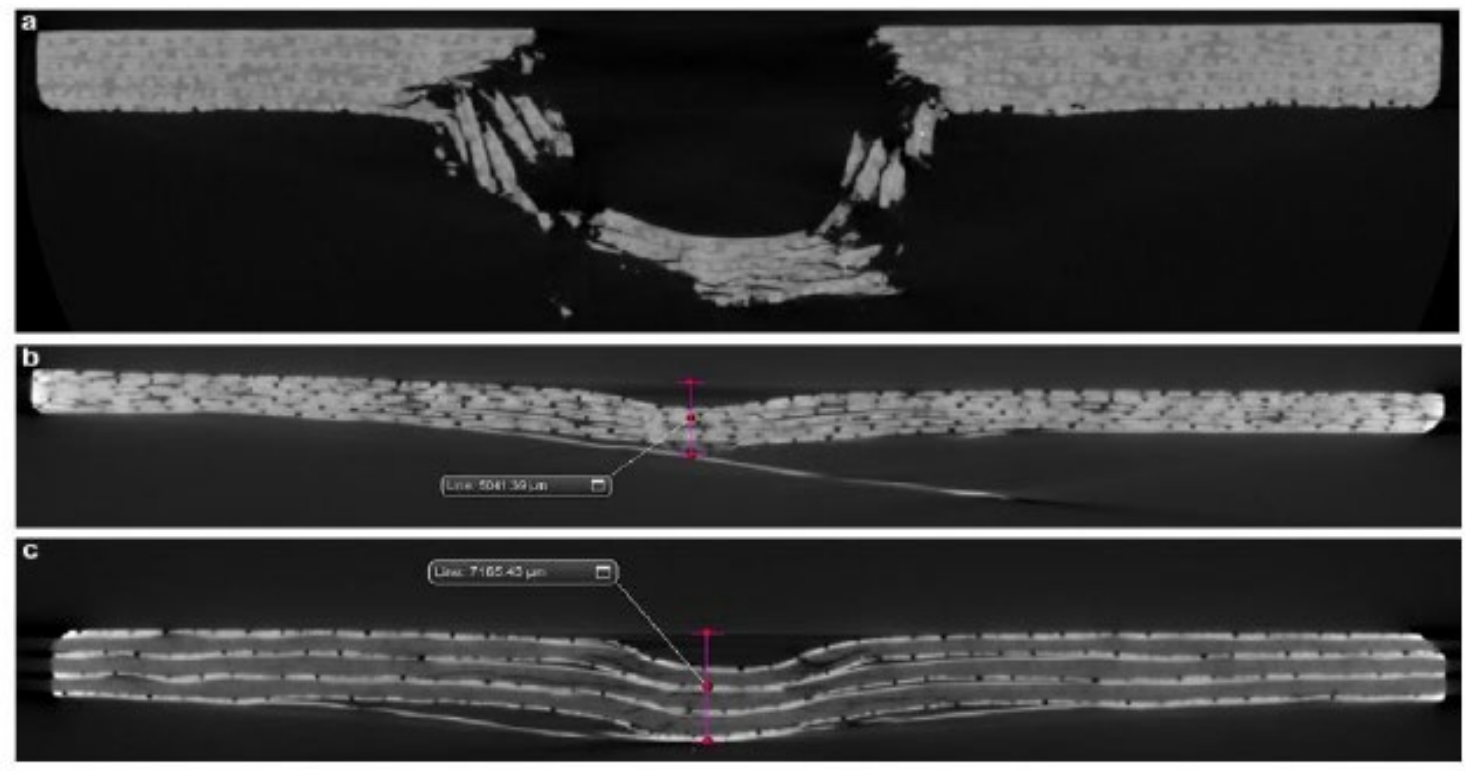

Fig. 19. Cross-sectional X-ray image of the X.Y. plane of the (a) flax fibre, (b) glass fibre, and (c) hybrid glass/flax reinforced composite specimen [11]

\section{Table 10}

Summary of the impact test of Natural and Synthetic Hybrid composites.

\begin{tabular}{|c|c|c|c|c|c|c|c|c|c|}
\hline $\begin{array}{c}\text { Hybrid } \\
\text { composite } \\
\text { type }\end{array}$ & Matrices & $\begin{array}{l}\text { Manufactu } \\
\text { ring of } \\
\text { composites }\end{array}$ & $\begin{array}{c}\text { Dimensio } \\
\text { n of } \\
\text { specimens } \\
\text { mm }\end{array}$ & $\begin{array}{c}\text { Impactor } \\
\text { type and size }\end{array}$ & $\begin{array}{c}\text { Type } \\
\text { of } \\
\text { impact }\end{array}$ & $\begin{array}{c}\text { Hybrid } \\
\text { sample } \\
\text { type/sequence }\end{array}$ & $\begin{array}{c}\text { Maximum } \\
\text { energy } \\
\text { absorbed } \\
\text { J }\end{array}$ & $\begin{array}{c}\text { Maximum } \\
\text { load } \\
\text { N }\end{array}$ & References \\
\hline $\begin{array}{l}\text { Carbon/glas } \\
\mathrm{s}\end{array}$ & Vinyl ester & $\begin{array}{l}\text { Vacuum } \\
\text { resin } \\
\text { infusion }\end{array}$ & $100 \times 150$ & $\begin{array}{l}\text { Cylindrical } \\
\text { impactor } \\
D=19.8 \mathrm{~mm}\end{array}$ & $\begin{array}{l}\text { Low- } \\
\text { velocity } \\
\text { impact }\end{array}$ & G10, C5 & 96 & $9944, .22$ & [227] \\
\hline $\begin{array}{l}\text { Carbon/Gla } \\
\text { ss } \\
\text { Hybrid } 4 \\
\text { layers } \\
{[0 / 45,-} \\
45 / 90]\end{array}$ & $\begin{array}{l}\text { Epoxy } \\
\text { resin }\end{array}$ & $\begin{array}{l}\text { Resin } \\
\text { transfer } \\
\text { molding }\end{array}$ & $100 \times 150$ & $\begin{array}{l}\text { Hemisphere } \\
\text { impactor } \\
\mathrm{D}=12.7 \mathrm{~mm}\end{array}$ & $\begin{array}{l}\text { Low- } \\
\text { velocity } \\
\text { impact }\end{array}$ & $\begin{array}{l}\text { C.G. (1:1) } \\
\text { CGGG (1:4) }\end{array}$ & $\begin{array}{l}28-30 \\
30\end{array}$ & $\begin{array}{l}9000 \\
8600-8800\end{array}$ & [228] \\
\hline $\begin{array}{l}\text { Carbon/ } \\
\text { Glass/basalt }\end{array}$ & $\begin{array}{l}\text { Epoxy } \\
\text { resin }\end{array}$ & $\begin{array}{l}\text { Vacuum- } \\
\text { assisted } \\
\text { resin } \\
\text { infusion }\end{array}$ & $100 \times 100$ & $\begin{array}{l}\text { Hemispherical } \\
\text { impactor } \\
\mathrm{D}=12.7 \mathrm{~mm}\end{array}$ & $\begin{array}{l}\text { Low- } \\
\text { velocity } \\
\text { impact }\end{array}$ & $\begin{array}{l}\text { B-50 } \\
\text { B-60 } \\
\text { UD-B-50 } \\
\text { UD-B-60 }\end{array}$ & $\begin{array}{l}42.71 \\
59.43 \\
42.70 \\
55.00\end{array}$ & $\begin{array}{l}9.17 \mathrm{KN} \\
8.97 \\
8.35 \\
8.92\end{array}$ & [229] \\
\hline $\begin{array}{l}\text { Basalt - } \\
\text { Carbon }\end{array}$ & $\begin{array}{l}\text { Epoxy } \\
\text { resins }\end{array}$ & $\begin{array}{l}\text { Prepeg lay- } \\
\text { up process }\end{array}$ & $\begin{array}{l}100 \times 100 \\
\text { Thickness } \\
=4-4.44\end{array}$ & $\begin{array}{l}\text { Gas gun } \\
\mathrm{D}=7.5 \mathrm{~mm} \\
\mathrm{M}=1.725 \mathrm{~kg}\end{array}$ & $\begin{array}{l}\text { High- } \\
\text { velocity } \\
\text { Impact }\end{array}$ & BCBI & $\begin{array}{l}\text { Flexural } \\
\text { modulus } \\
765 \pm \\
16.77\end{array}$ & $\begin{array}{l}\text { The velocity } \\
\text { of } 247 \\
\mathrm{~m} / \mathrm{sec}\end{array}$ & [230] \\
\hline
\end{tabular}




\begin{tabular}{|c|c|c|c|c|c|c|c|c|c|}
\hline $\begin{array}{l}\text { Basalt/Flax } \\
\text { twill } \\
\text { laminates }\end{array}$ & $\begin{array}{l}\text { Epoxy } \\
\text { resins }\end{array}$ & $\begin{array}{l}\text { Resin } \\
\text { infusion } \\
\text { fabrication } \\
\text { technology }\end{array}$ & $100 \times 100$ & $\begin{array}{l}\text { Cylindrical } \\
\text { impactor } \\
\mathrm{D}=19.8 \mathrm{~mm} \\
\mathrm{M}=3.64 \mathrm{~kg}\end{array}$ & $\begin{array}{l}\text { Low - } \\
\text { velocity } \\
\text { impact }\end{array}$ & Flax/Basalt & 20 & $8000 \mathrm{~N}$ & [231] \\
\hline $\begin{array}{l}\text { Flax/Glass } \\
\text { hybrid }\end{array}$ & Vinyl ester & $\begin{array}{l}\text { Vacuum } \\
\text { infusion } \\
\text { process }\end{array}$ & $\begin{array}{l}\text { Square } \\
\text { specimens } \\
4.5 \mathrm{~mm} \mathrm{t} \\
60 \times 60\end{array}$ & $\begin{array}{l}\text { Hemispherical } \\
\text { nose impact } \\
\mathrm{D}=19 \mathrm{~mm} \\
\mathrm{M}=23.11 \mathrm{~kg}\end{array}$ & $\begin{array}{l}\text { Low - } \\
\text { velocity } \\
\text { impact }\end{array}$ & $\begin{array}{l}\text { Flax/VE } \\
\text { Glass/VE } \\
\text { Flax/Glass/VE } \\
\text { hybrid }\end{array}$ & 50 & $\begin{array}{l}16000 \\
5500 \\
13000\end{array}$ & [11] \\
\hline $\begin{array}{l}\text { Flax/ Glass } \\
\text { Polypropele } \\
\text { ne }\end{array}$ & $\begin{array}{l}\text { Polypropyl } \\
\text { ene }\end{array}$ & $\begin{array}{l}\text { Vacuum- } \\
\text { assisted } \\
\text { compressio } \\
\mathrm{n} \\
\text { molding }\end{array}$ & $\begin{array}{l}150 \times 150 \\
\times 3.5\end{array}$ & $\begin{array}{l}\text { Hemispherical } \\
\text { nose } \\
\mathrm{D}=12 \mathrm{~mm}\end{array}$ & $\begin{array}{l}\text { Low - } \\
\text { velocity } \\
\text { impact }\end{array}$ & $\begin{array}{l}\text { Glass- P.W. } \\
\text { Roving - P.W. } \\
\text { Roving - U.D. }\end{array}$ & $\begin{array}{l}18.71 \pm 1.29 \\
13.81 \pm 1.53 \\
23.10 \pm 1.11\end{array}$ & $\begin{array}{l}2.72 \pm 0.29 \\
1.61 \pm 0.55 \\
2.72 \pm 0.29\end{array}$ & [233] \\
\hline Kenaf/Glass & $\begin{array}{l}\text { Epoxy } \\
\text { resin }\end{array}$ & $\begin{array}{l}\text { Hand- } \\
\text { layup } \\
\text { process }\end{array}$ & $100 \times 150$ & $\begin{array}{l}\text { Drop test } \\
\text { Height }-0.8 \\
\mathrm{~m}\end{array}$ & $\begin{array}{l}\text { Low - } \\
\text { velocity } \\
\text { impact }\end{array}$ & Kenaf/Glass & 23.33 & $9.3 \mathrm{KN}$ & [232] \\
\hline
\end{tabular}

\section{Novel improvement techniques of natural fibres composites and their hybrids to enhance damage tolerance and impact resistance.}

The main purpose of this paper is to identify the effective techniques or methods for enhancing the damage tolerance and impact resistance of natural fibre hybrid polymer composites and their hybrids. This section will broadly discuss the critical parameters of polymer matrix composites such as STF, 3D metallic coating, stitching, Z-pinning and hybrid techniques.

\subsection{STF: working mechanisms, benefits in comparison to other techniques}

\subsubsection{Background of STF}

STF also called as the dilatant fluid has gained attention for the impact protection, for its unique viscosity [234]. It a Non-Newtonian flow of behaviour when the viscosity of the fluid increases with the shear rate or applied stress [235]. The fluid behaviour has been observed mainly in the concentrated colloidal suspensions [236]. Fig. 20 shows the schematic illustration of the shearthickening behaviour. At rest, the liquid present is enough to fill the void when space is minimum. Then, the liquid slowly fills into a paste and suddenly becomes a substantial under low shear stress. At high shear stress, the viscosity of fluid behaviour increases drastically and turns solid. It is entirely reversible; the suspension could return to the easy flowing state or flow like any other liquid after removing impact stress [237-240]. There are different theories for explaining the mechanism of shear thickening, and many researchers proposed orderdisorder theory and hydrodynamic clustering are the two widely accepted theories [241]. 

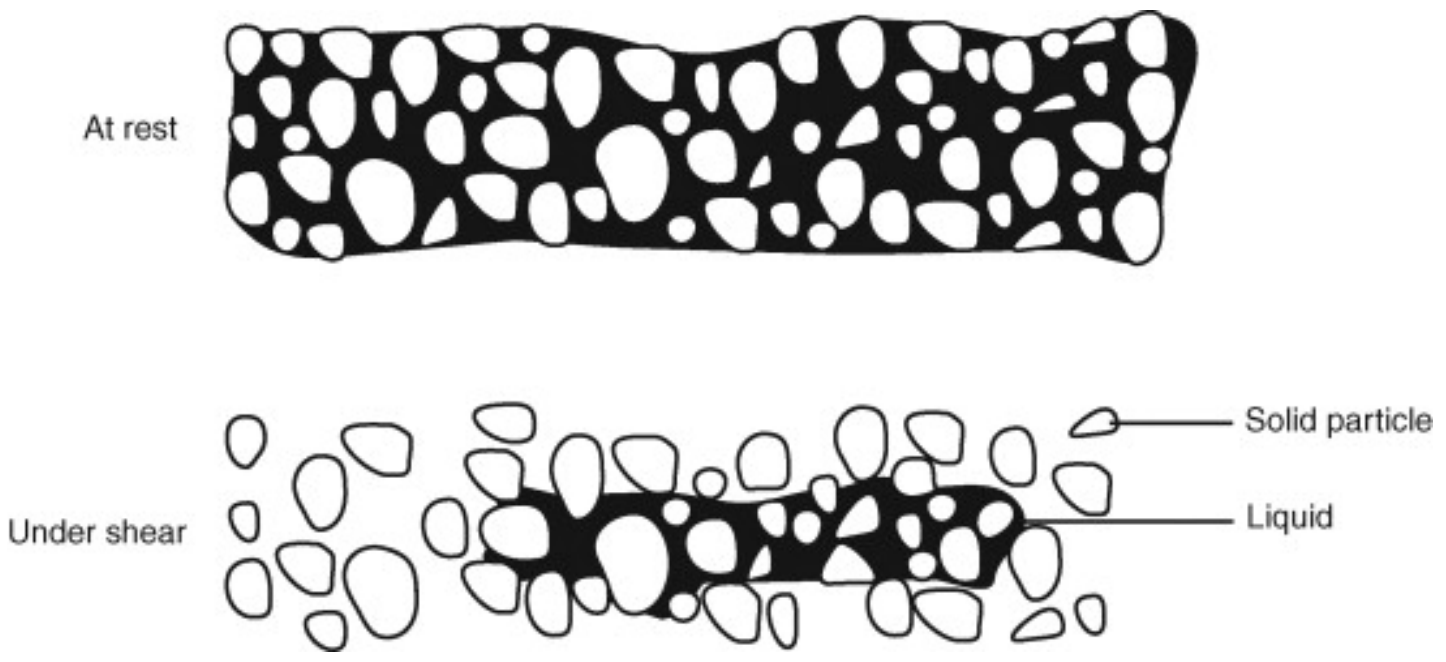

Fig. 20. Schematic representation of the shear- thickening behaviour [236]

\subsubsection{Rheological behaviour of STF that improves the impact properties of the composites.}

Balali et al. [242] investigated a rheological behaviour of STF for the glass fibre reinforced composites under a low-velocity impact test. Initially, they diluted ethanol with the STF for the weight ratio of ethanol and STF at 3:1. Then, they fabricated glass fabric layers with $16 \mathrm{~cm} \mathrm{x}$ $16 \mathrm{~cm}$ soaked with the ethanol and STF for $1 \mathrm{~min}$ and baked at $60^{\circ} \mathrm{C}$ until they were dry and ethanol had evaporated. Later, they observed that different combinations of STF, STF nanosilica, and STF nano clay treated with glass fibres shown in Table 11 achieved a superior energy absorption with maximum load toleration. Fu et al. [243] studied the rheological behaviour of STF and STF filled sandwich composite panels (SCP) with carbon fibre reinforced composites under the low-velocity impact test. It was noted that $58 \mathrm{vol} \%$ of styrene/acrylate particles were mixed with ethylene glycol (EG) showed a higher energy absorption capacity than an aluminium foam. However, the experimental resulted that SCF with a thin core exhibits the higher absorption energy with $99.3 \%$, and a thick core showed impact damage was effectively suppressed on the back surface of SCPs. Y. S. Lee et al. [244], stated that kevlar fabric with ethylene glycol showed a lower energy dissipation results owing to the decreasing friction. However, the presence of STF impregnated with kevlar fibre exhibited a significant increase in energy dissipation with an increased volume of STF. Selver [245] observed that during the manufacturing process (Fig.21.), the carbon fabric (d) absorbs more STF than the glass fabric in Fig. 21 (b) with better STF holding. Further, the author noticed with silica particles; the shear thickening did not show any behaviour on glass/epoxy composites. However, this changes the interfacial bonding and impact resistance of the composite laminates. 
In recent studies, polyurethane (PU) performs excellent energy absorption and resilience for the functional protective materials [246-248]. Wu et al. [249], experimented STF with 30\%, $50 \%$, and $70 \%$ for flexible woven composite with polyurethane glycol (PEG). They observed that higher STF content yields a positive influence on the dynamic resistance of the composites. Moreover, the volume fraction of $70 \% \mathrm{wt}$ achieved a higher impact strength to that of the composites treated without STF. Even Caglayan et al. [250] produced similar results in the Shear thickening fluid-filled with Polyurethane (PU) foam core sandwich composites. They stated that STF filled with PU exhibits a higher impact and compressive strength compared to neat PU foams. Furthermore, they observed that $1 \mathrm{wt} \% \mathrm{STF}-40 / \mathrm{PU}$ was the active foam core in terms of impact resistance. Also, the highest percentage of energy absorption for the received impact energy was achieved with the lowest possible damage of $13 \%$.

\section{Table 11}

Combinations of Glas fibres treated with STF [242]

\begin{tabular}{ll}
\hline Samples & Weight (gm) \\
\hline Four layers of neat glass fabric & 34.8 \\
Four layers of glass + hybrid STF (20\% of nano-silica) & 45.7 \\
Four layers of glass + hybrid STF (30\% of nano-silica) & 47.9 \\
Four layers of glass + hybrid STF (30\% of nano-silica and 1\% nano-clay) & 48.9 \\
Four layers of glass + hybrid STF (30\% of nano-silica and 3\% nano-clay) & 50.2
\end{tabular}


(a)

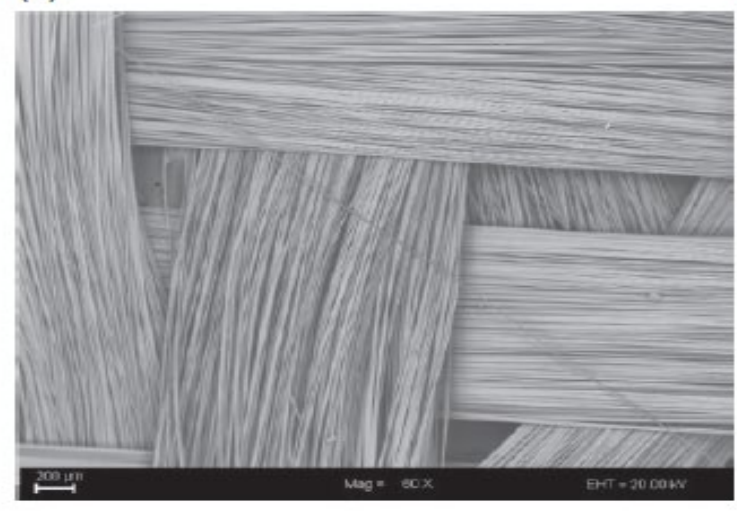

(c)

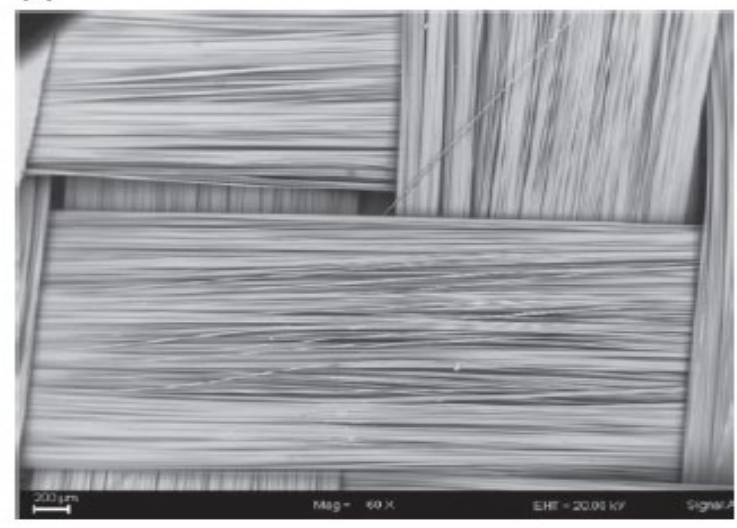

(b)

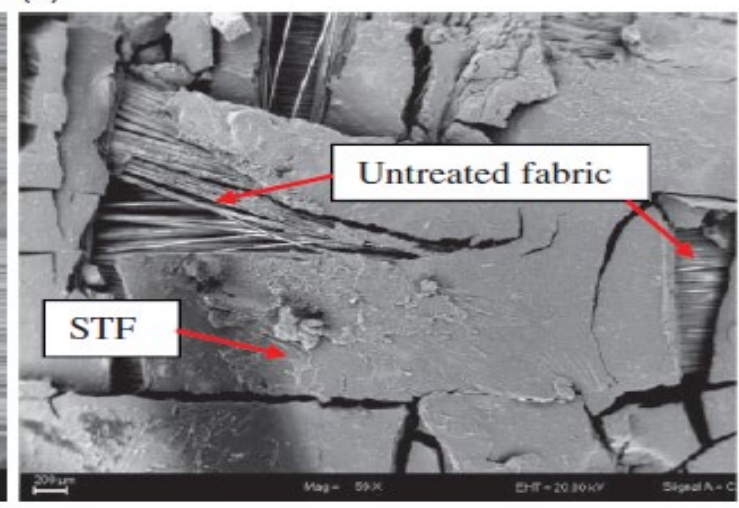

(d)

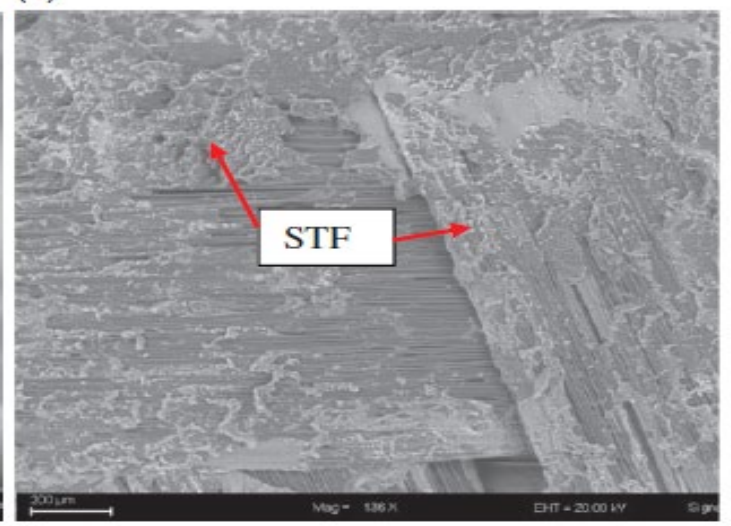

Fig. 21. SEM images of: (a) GF, (b) GF20, (c) CF and (d) CF20 fabric samples [245].

\subsubsection{Experimental and Numerical analysis of the impact test of hybrid composites filled with}

\section{STF - Review}

\section{Experimental analysis}

Selver [245] studied the impact and damage tolerance of carbon and glass fabric composites treated with silica ratios of $10 \%, 15 \%$, and $20 \%$, respectively. A drop weight impactor with a $16 \mathrm{~mm}$ diameter striker was used. The experiment showed that glass and carbon treated with STF achieved more energy in the low impact test of 20 -30 J with a load of $2900-3500 \mathrm{~N}$ than pure glass and carbon composites. However, Balali et al. [242] noticed similar results in the glass fibre reinforced hybrid with STF. The maximum energy for the neat glass fabrics was absorbed in $2.57 \mathrm{~J}$, and the highest of $140.825 \mathrm{~N}$. While the STF/glass and STF/nano-clay/glass fabrics exhibit a superior penetration compared to neat glass fabrics. For $30 \mathrm{wt} \%$ concentration STF and $3 \mathrm{wt} \%$ concentration nano-clay, the accepted load was at $1773.7 \mathrm{~N}$ with the absorbed energy of $43.5 \mathrm{~J}$.

Pinto \& Meo, [251] worked on improving hybrid composite by adding silica-based liquid in a carbon fibre reinforced polymer laminate (CFRP). A drop test rig of a spherical head geometry 
of $20 \mathrm{~mm}$ diameter with a mass of $12.684 \mathrm{~kg}$ as an impactor. They noticed the peak remained linear at low-velocity impact (6J). While at 20J, it gradually moves from $4252 \mathrm{~N}$ to $4742 \mathrm{~N}$ with STF (Fig. 22.). However, the curve showed a dramatic increase in the 40J impact test because of hybridisation. The peak moves from $5197 \mathrm{~N}$ for the unreinforced samples to a highest of $6929 \mathrm{~N}$ for the STF based ones $(\sim 30 \%)$. Therefore, the results could not achieve for low-velocity impacts as the hydrocluster activation mechanism requires a relatively high solidification. Even Asija et al. [252], produced a similar result for UHMWPE variant shield and Spectra shield. They observed that STF treated panels absorb less energy at low impact tests compared to the untreated panels for the deflections at peak load. Nevertheless, the peak load absorbs the higher energy at higher impacts when the composites treated with STF. According to author Lu et al. [253] stated that the ballistic performance of STF under a high velocity of $450-510 \mathrm{~m} / \mathrm{sec}$, does not show much improvement due to increased mass and the degradation of maximum perforation velocity of the yarns in the fabric. However, they noted that aramid fabric panels under STF provide a better shielding performance in a low- velocity impact test.

$\mathrm{Fu}$ et al. [243] examined the mechanical performance, namely rheological, low-velocity behaviour of STF, and STF filled with sandwich composite panels (SCP). It was noted in Fig 23(a), the STF stiffness is initially low when the striker impacts the front-facing, because of densification. Whereas when the striker reaches the backplate, see Fig 23 (d), the STF already gets compressed severely, and they are fully densified. Therefore, a higher resisting force is observed due to high supporting stiffness of STF in the second peak. However, the author also observed that the impact behaviour of SCP was significantly improved with the STF concentrations

Regarding Natural fibres treated with STF, Abhishek et al. [254], investigated Jute/E-glass with epoxy resins by adding STF as a fourth element. They observed that jute fibre loading with STF performs good results in tensile and elastic properties in contrast to other composites. A detailed summary of the impact test of composites treated with STF shown in Table 12. 

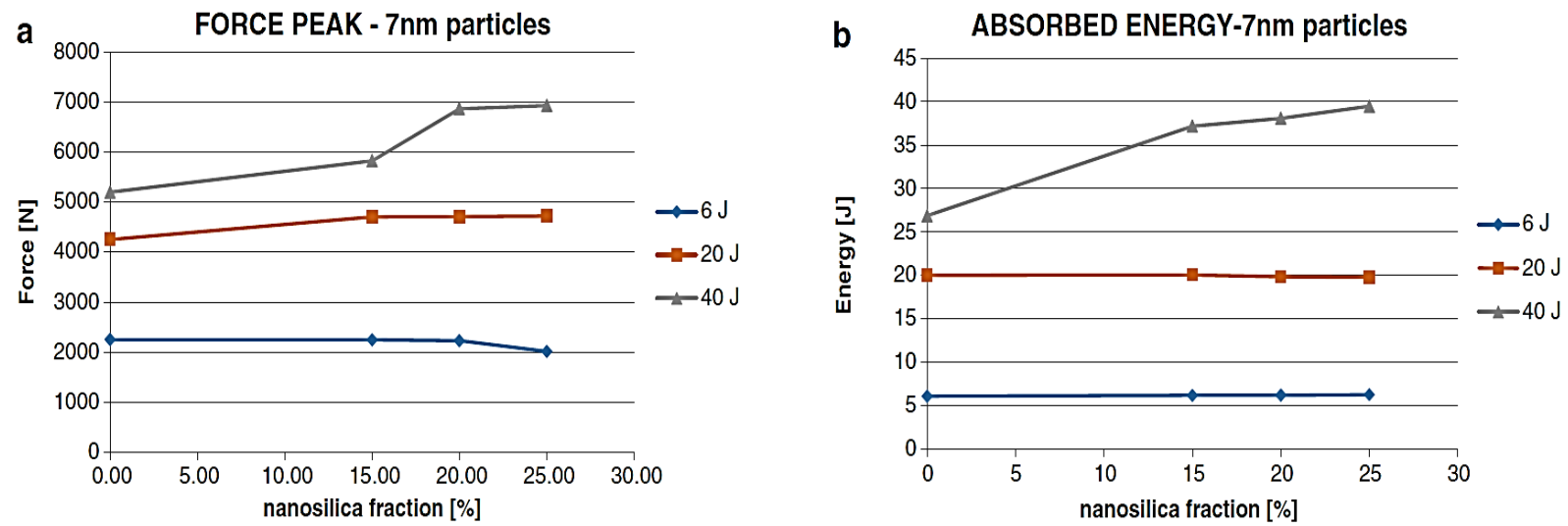

Fig. 22. (a) Force Peak variation at different energies and different silica concentrations in STF; (b) Energy absorption variation at different energies and different silica concentrations in STF [251]

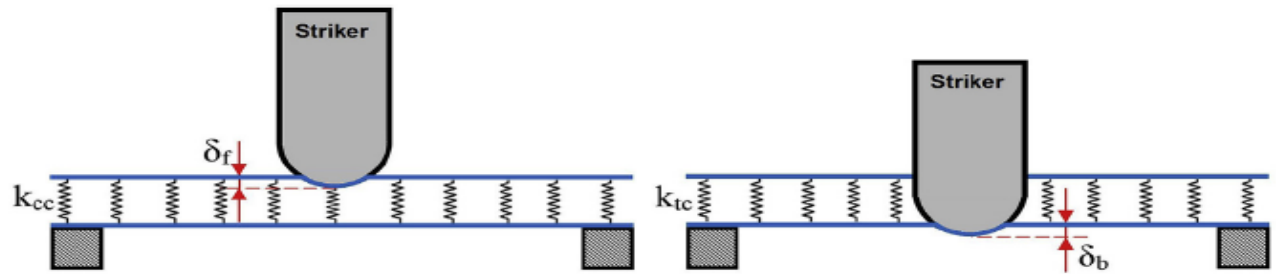

(a)

(b)

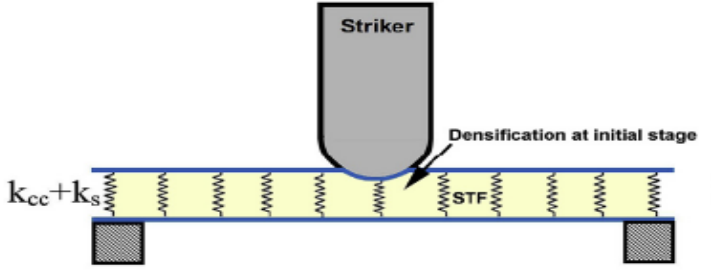

(c)

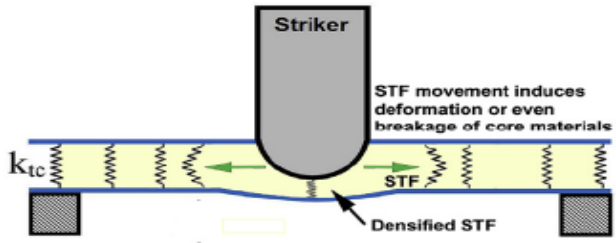

(d)

Fig 23. Schematic impact on (a) pristine front-facing (b) pristine back facing (c) STF filled frontfacing (d) STF filled back facing [243]

\section{Table 12}

Summary of impact test of composites treated with STF

$\begin{array}{cccccccc}\begin{array}{c}\text { Composite } \\ \text { samples }\end{array} & \begin{array}{c}\text { Type of } \\ \text { Impactor }\end{array} & \begin{array}{c}\text { Specificati } \\ \text { on of } \\ \text { impactor }\end{array} & \text { Type of STF } & \begin{array}{c}\text { Impact- } \\ \text { low/high }\end{array} & \text { Peak force } & \begin{array}{c}\text { Maximum } \\ \text { energy } \\ \text { absorbed }\end{array} & \text { References } \\ & & & & & \text { absor }\end{array}$

(N)

(J)

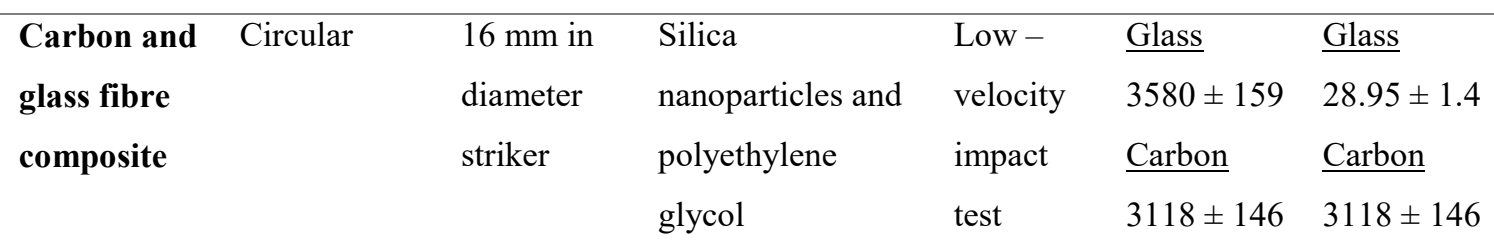




\begin{tabular}{|c|c|c|c|c|c|c|c|}
\hline $\begin{array}{l}\text { Glass fibre } \\
\text { reinforced } \\
\text { STF }\end{array}$ & $\begin{array}{l}\text { Circular/ } \\
\text { Round }\end{array}$ & $\begin{array}{l}16 \mathrm{~mm} \text { in } \\
\text { diameter }\end{array}$ & $\begin{array}{l}200 \mathrm{~g} \text { of silica } \\
\text { nanoparticles and } \\
400 \mathrm{~g} \text { of } \\
\text { polyethylene } \\
\text { glycol }\end{array}$ & $\begin{array}{l}\text { Low - } \\
\text { velocity } \\
\text { impact } \\
\text { test }\end{array}$ & 1773.6 & 43.5 & [242] \\
\hline $\begin{array}{l}\text { Sandwich } \\
\text { composite } \\
\text { with } \\
\text { polyurethan } \\
\text { e grid }\end{array}$ & $\begin{array}{l}\text { Circular flat } \\
\text { compressive } \\
\text { heads }\end{array}$ & $\begin{array}{l}80 \mathrm{~mm} \text { in } \\
\text { diameter }\end{array}$ & $\begin{array}{l}200 \mathrm{~g} \text { of } \\
\text { polyethylene } \\
\text { glycol and } 200 \mathrm{~g} \\
\text { of } \mathrm{SiO}_{2}\end{array}$ & $\begin{array}{l}\text { Low - } \\
\text { velocity }\end{array}$ & 3000 & $\begin{array}{l}4827.46 \\
\text { MJ for } \\
70 \% \text { STF }\end{array}$ & [249] \\
\hline $\begin{array}{l}\text { Sandwich } \\
\text { composite } \\
\text { panels with } \\
\text { STF }\end{array}$ & $\begin{array}{l}\text { Cylindrical } \\
\text { striker }\end{array}$ & $\begin{array}{l}12.7 \mathrm{~mm} \text { in } \\
\text { diameter }\end{array}$ & $\begin{array}{l}58 \mathrm{wt} \% \\
\text { styrene/acrylate + } \\
\text { ethylene glycol }\end{array}$ & $\begin{array}{l}\text { Low - } \\
\text { velocity }\end{array}$ & 1069.3 & 26.718 & [243] \\
\hline $\begin{array}{l}\text { UHMWPE } \\
\text { variants } \\
\text { gold shield } \\
\text { and spectra } \\
\text { shield }\end{array}$ & $\begin{array}{l}\text { Hemispheric } \\
\text { al impactor }\end{array}$ & $\begin{array}{l}15.585 \mathrm{~mm} \\
\text { in diameter }\end{array}$ & $\begin{array}{l}400 \mathrm{~g} / \mathrm{mole} \text { of } \\
\text { polypropylene } \\
\text { glycol and ethyl } \\
\text { alcohol }\end{array}$ & $\begin{array}{l}\text { Low and } \\
\text { high } \\
\text { velocity }\end{array}$ & 1283.1 & 14.45 & [252] \\
\hline $\begin{array}{l}\text { Sandwich } \\
\text { composites }\end{array}$ & $\begin{array}{l}\text { Hemispheric } \\
\text { al metal } \\
\text { crosshead }\end{array}$ & $\begin{array}{l}10 \mathrm{~mm} \text { in } \\
\text { diameter }\end{array}$ & $\begin{array}{l}\text { Silica } \\
\text { nanoparticles }+ \\
\text { ethylene glycol }\end{array}$ & $\begin{array}{l}\text { Low } \\
\text { velocity }\end{array}$ & 1550 & $\begin{array}{l}18.50 \pm \\
0.53\end{array}$ & [250] \\
\hline $\begin{array}{l}\text { Carbon } \\
\text { fibre } \\
\text { reinforced } \\
\text { STF }\end{array}$ & $\begin{array}{l}\text { Semi- } \\
\text { spherical } \\
\text { head } \\
\text { geometry }\end{array}$ & $\begin{array}{l}20 \mathrm{~mm} \text { in } \\
\text { diameter }\end{array}$ & $\begin{array}{l}10 \text { to } 25 \mathrm{wt} \% \text { of } \\
\text { silica particles } \\
\text { with polyethylene } \\
\text { glycol }\end{array}$ & $\begin{array}{l}\text { Low } \\
\text { velocity }\end{array}$ & $6929 \mathrm{~N}$ & $40 \mathrm{~J}$ & {$[251]$} \\
\hline
\end{tabular}

\section{Numerical analysis}

Numerical modelling is comfortable and straightforward ways of solving highly dynamic and complex geometries cost-effectively [255]. Also, the material can be modelled from 2Dimensional to 3-Dimensional at different resolutions. This includes many informative results, such as stress-strain behaviour, residual velocity, contact force, and failure patterns. There are different approaches to model the behaviour of fabrics under low/high impact tests, amongst which shell and solid- element method are the most preferred by researchers $[255,256]$. For modelling the STF, Arbitrary Lagrangian Element (ALE) is mainly considered for applications where fluid-structure interaction must be considered [257]. Rizzo et al. [257] investigated a numerical analysis of CFRP plates with silica-based STF. A rectangular plate of $150 \mathrm{~mm} x$ $150 \mathrm{~mm} \times 2 \mathrm{~mm}$ was modelled using a 3D Solid finite element method and simulated by using 
a quasi-isotropic stacking sequence $[0 / 90 /+45 /-45]_{\text {s. }}$ An LS-Dyna code made the 3D model with a constant stress formulation of $0.25 \mathrm{~mm}$ thickness, and the impactor was modelled as a hemispherical static body of mass $12.864 \mathrm{~kg}$ and $20 \mathrm{~mm}$ in diameter. STF was placed at three different locations shown in Fig. 24. ALE formulation was used to model the STF in LS-Dyna. They found the numerical model could simulate the damaged area of mechanisms of $\mathrm{STF} / \mathrm{CFRP}$ with an error of 9 to $12 \%$ between the experimental and simulated results. Also, it can anticipate the impact behaviour of the STF/CFRP system allowing the optimisation of the STF to maximise the impact properties.

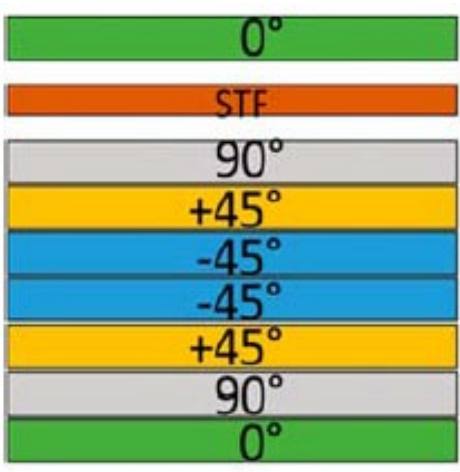

TOP STF

(a)

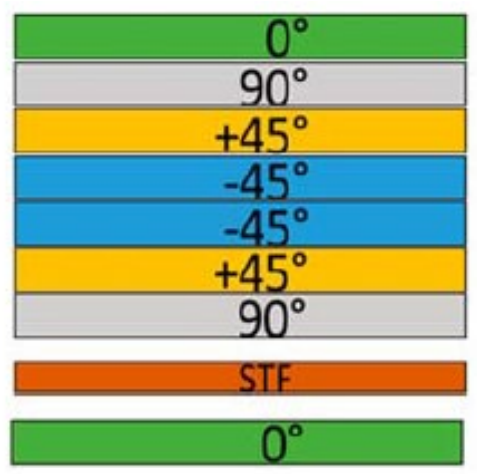

BOTTOM STF

(b)

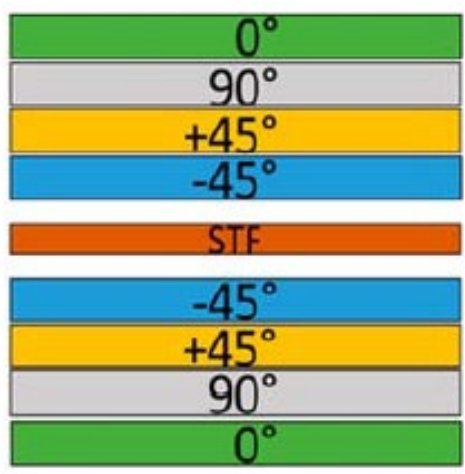

CENTRAL STF

(c)

Fig .24. Location of STF layer with CFRP thickness (a) STF placed close to the contact surface (b) STF is placed far from the contact surface (c) STF placed on the midplane of the laminate [257].

Sen et al. [258] developed the kevlar-STF model by using 3D solid elements, taking into account actual weave geometry and inter yarn friction. The inter yarn friction was developed by using Abacus element M3P4R (four noded membrane element with reduced integration) was used to mesh the geometry, and the kevlar fabric was modelled with a rectangular crosssection with a thickness of $0.23 \mathrm{~mm}$ and a wavelength of $1.548 \mathrm{~mm}$ respectively as shown in Fig. 25. A coupled Eulerian-Lagrangian (CEL) was used to model the STF, and the properties of STF are defined by using the Mie-Grüneisen equation of state described in Eq. (8). Initially, they modelled an STF- fabric composite by using a Lagrangian approach as fabric experienced in the smaller deformation, and later, they modelled STF by using an Eulerian approach due to the fluid at a lower strain, which acts as a larger deformation. While comparing the experimental and numerical results, the author noticed that the proportion of energy absorption 
showed similar results in all the test cases. Even Wetzel [259] also observed similar results for experimental and numerical behaviour of STF-kevlar composites.

The equation of Mie-Grüneisen is given by:

$$
p=\frac{\rho_{0} C_{0}{ }^{2} x}{(1-s x)^{2}}\left(1-\frac{\Gamma_{0} x}{2}\right)+\Gamma_{0} E
$$

Where,

$\mathrm{p}=$ pressure

$\mathrm{C}_{0}=$ sound speed through the medium

$\mathrm{X}=1-\left(\rho_{0} / \rho\right)$ where $\rho_{0}$ is the initial energy and $\rho$ is the current density

$\Gamma_{0}=$ material constant

$\mathrm{S}=\mathrm{dU}_{\mathrm{s}} / \mathrm{dU}_{\mathrm{p}}$ is a linear Hugoniot slope coefficient

$\mathrm{U}_{\mathrm{s}}=$ shock wave velocity

$\mathrm{U}_{\mathrm{p}}=$ partial veloicity

$\mathrm{E}=$ internal energy per unit reference volume

Hasanzadeh et al. [260] investigated the numerical analysis of multilayered plain-woven HMPP fabrics filled with STF by using LS- Dyna. An eight noded solid element was used to simulate the woven fabric and projectile in contrast to the original study, which used shell elements by B. W. Lee \& Kim [261]. In both studies, STF was used as a polyethylene glycol weighing $200 \mathrm{~g} / \mathrm{mol}$. However, the particle size and the fabric were different for both the studies. Hasanzadeh et al. [260] used HMPP fabric with a particle size of $12 \mathrm{~nm}$ while B. W. Lee \& Kim [261] used kevlar fabric with a particle size of 100-500nm. The only difference was the yarn pull - out speed was observed, and it showed a massive difference in both investigations. Hasanzadeh et al. [260] observed speed of $1.67 \mathrm{~mm} / \mathrm{sec}$, which was lesser than the original study by B. W. Lee \& Kim [261] in which the STF impregnated kevlar fabric was claimed to be invoked at $23.3 \mathrm{~mm} / \mathrm{sec}$. These factors are likely to cause a difference in the shear thickening behaviour of the two systems. Besides, there is no information available on userdefined friction subroutines used in Hasanzadeh et al. [260] simulations, even though they say that simple Coulomb friction has been implemented and updated to account for the shear thickening effect. Moreover, Hasanzadeh et al. [260] compared the numerical and experimental results of HMPP fabric impregnated with STF for the depth of indentation. They observed that the numerical findings were in close agreement with the corresponding experimental results. 


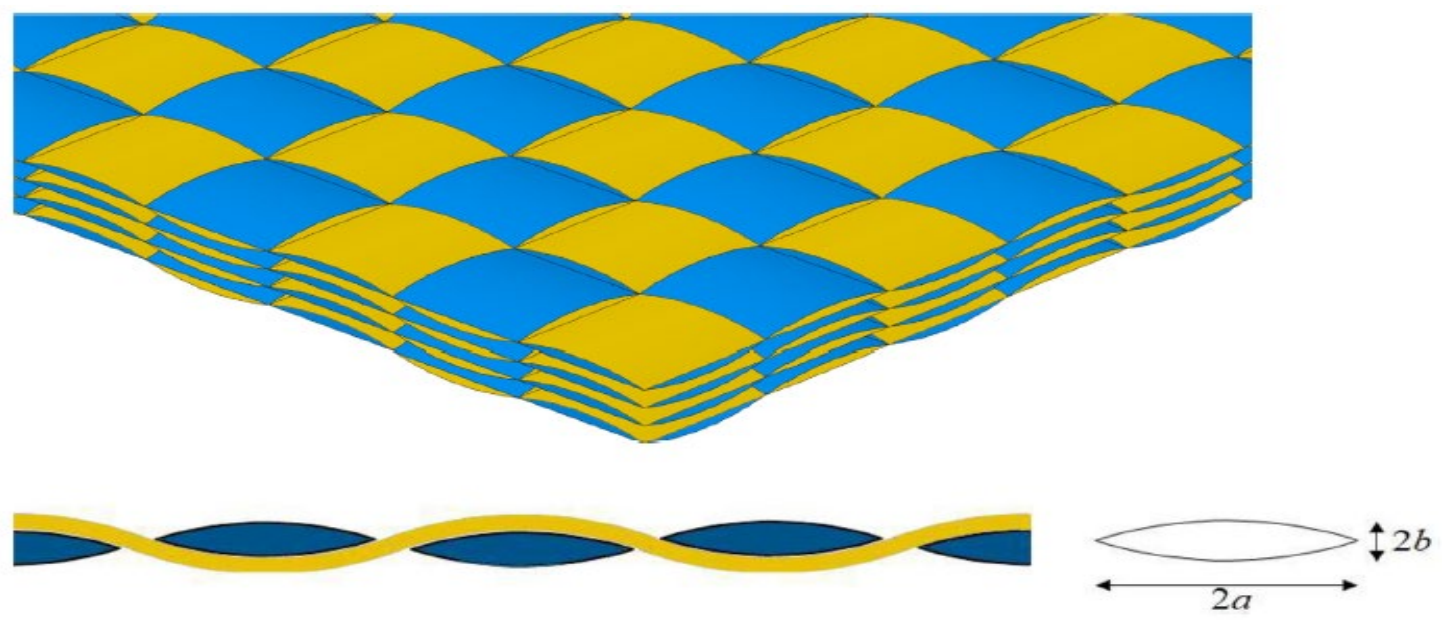

Fig .25. Schematic diagram of cross-sections of the fabric [258].

Chauhan et al. [262] studied the Lagrangian method for examining the characteristics of STF with an eulerian carrier fluid. Water was chosen as the carrier fluid with a viscosity of 0.0091 poise, and a silica density of $20196 \mathrm{~g} / \mathrm{m}^{3}$ was modelled by using ANSYS CFX. As shown in Fig. 26, the diameter of each spherical $\mathrm{SiO}_{2}$ was $2 \mathrm{~mm}$ with an applied flow velocity $2 \mathrm{~m} / \mathrm{s}$. They observed that by applying higher velocity and acceleration to the STF domain, there would be a possibility of achieving a higher shear thinning effect. On the other hand, the use of sand particles could improve the viscosity of the STF, resulting in an improved shear thickness of the dilatant fluid.
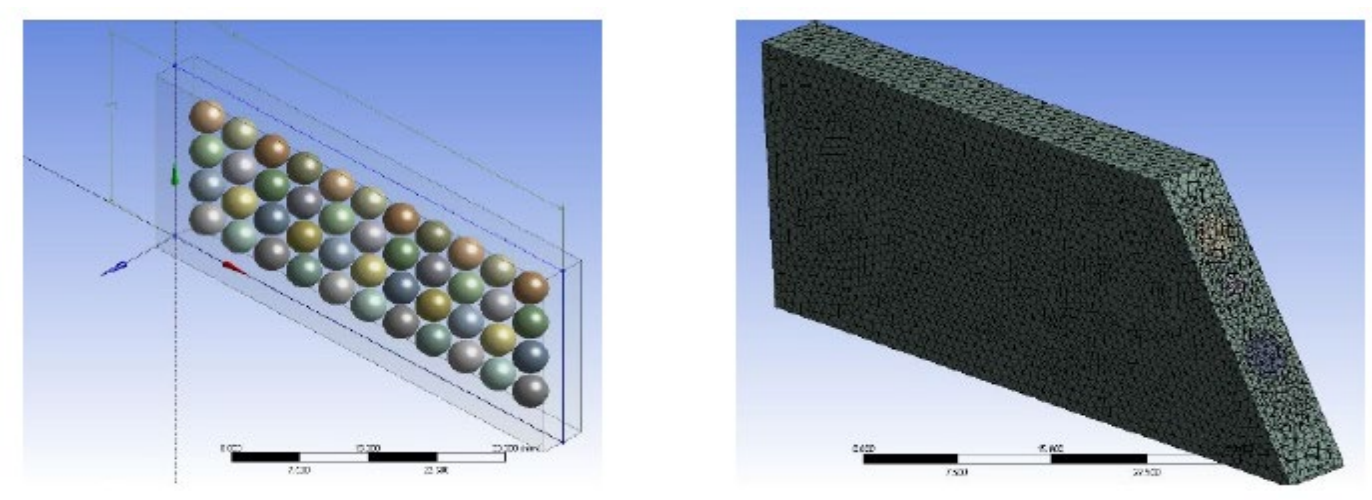

Fig.26. Geometry and meshing of Shear thickening fluid model [262].

\subsubsection{Natural fibres with STF benefits in contrast to other techniques.}

A detailed study on the shear thickening fluid with natural fibres are inadequate. It is, therefore, essential to develop and optimise the use of STF in the hybrid combinations with natural fibres along with the traditional fibres. However, there are numerous types of application of composite structures built with STF, such as Kevlar, ceramic, and UHMWPE. Previous experiments were conducted to develop the performance of materials used in defence 
applications, such as bulletproof jackets and armoured helmets [263,264]. Further, advanced materials like aerogel and carbon nanotubes (CNT) coupled with conventional composite materials, would enhance the capability of resisting bullet impact to a certain extent [265]. Currently, there is a significant interest in developing impact-resistant fabrics such as Kevlar built on the shear thickening fluid (STF) [244,258,259,266,267]. Besides, STF has shown promising results in protection and flexibility. Also, the use of STF with composites/fabrics still suffers several drawbacks like evaporation, leakage of carrier fluids, and air-moisture permeability for the clothing purpose. However, some fibres impregnated to STF faces many issues due to evaporation and leakage [268] As a result, evaporation of the STF fluid will be a vital issue in existing STF research. Remarkable efforts are being made to solve this problem in recent years. One of the efforts was to fill a hollow fibre with an STF [269]. However, by its nature, the STF is not easily pumped into the hollow fibres. In order to pump the STF into fibres, the viscosity of STF must be reduced, but in the case of shear response, STF will be acted accordingly.

\subsection{Metallic coating technique}

Additive manufacturing techniques are currently booming in the research interest due to the unique potentialities, among these the cold spray deposition technique is the most commonly used in the production of metallic layers on polymeric substrates [270]. In this technique, a uniform metallic coating is produced by accelerating solid particles in supersonic gas flow at a velocity of 300-1200 m/ sec and depositing them onto substrates [271,272]. When the powder particles have an impact on the target surface, the kinetic energy is converted into plastic deformation; the solid particles are deformed and bonded together, making it possible to form and produce coatings [273]. Extensive researches are done in the past on 3D coatings on metal and alloy substrates [274-278], but much less attention has been paid to polymeric substrates and in particular, composite materials [270,279,280]. The significance of this technique on polymer structures is to prevent damage to sensitive polymer substrates requiring metallization. In addition, electrically conducting coatings is produced because of minimal particle oxidation during the deposition cycle, which is an additional advantage over the thermal spray process [281]. Astarita et al. [282] studied the Metallic Coating on hemp-PLA laminates through the Cold Spraying Technique (CS). The coating was found to be very thick, and there were no visible voids or cavities present. Also, the properties of the hemp- PLA laminates were not affected by the deposition process, if the parameters are correctly set. Lupoi and O'Neill [283] 
investigated metallic coatings of glass fibre composites using cold spray deposition of copper, aluminium and tin on various thermoplastics (polyamide-6, polypropylene and polystyrene). They detected that CS of tin resulted in the successful deposition due to its low critical velocity resulting in low theoretical impact energy (10.7 times lower than copper). Whereas, erosion in copper was the most common effect. Ganesan et al. [270] compared the deposition mechanisms on thermoplastics and thermosetting substrates. They found that deposition of thermoplastics was possible through mechanical interlocking (particle embedment), while localised fracture was noticed for thermosetting substrates. Che et al. [284] investigated the carbon fibre reinforced polymer composites with both high-pressure and low-pressure CS systems. They concluded that erosion was considered to be a critical barrier to the development of coatings on CFRP substrates, as exposed and fractured carbon fibres were observed after particle impacts. Resulting, only individual particles embedded in the epoxy matrix. However, Fallah et al. [285] also noticed that delamination of the carbon fibre-reinforced polymers (CFRPs) by cold spray deposition occurred at higher gas pressures. The Copper coatings protect the CFRP from any possible damage but also improves the overall properties of the composites. Recently, Papa et al. [286] investigated novel composite structures of the basalt-PA6 substrate made of a polymer matrix composite with a superficial cold sprayed aluminium layer. Micron-sized aluminium particles have been used to metallise laminate surfaces. Different energy levels of impact tests have been carried out. They noticed that only a few damages were recorded on the treated laminates. Also, in Fig. 27, the energy absorbed by the neat system is significantly higher, indicating higher susceptibility to damage to the composite coating. Besides, the aluminium deposition damages the mechanisms that cause a lower indentation depth and a considerable plastic deformation. The author further concluded that the development of a 3D printed metal coating on a composite surface designed to minimise the damage caused by lowspeed impacts, leading to a novel composite structure, would lead to a significant improvement in impact strength.

Therefore, the coating techniques could satisfy the mechanical and impact properties of the composites. However, this novel technique could be challenging for natural fibre composites, especially for its poor wettability, excessive level of moisture absorption and inadequate adhesion. If this could be successful, then this method would be the rapid replacement for synthetic fibres and makes the composites stronger, resulting in competitive advantages. 


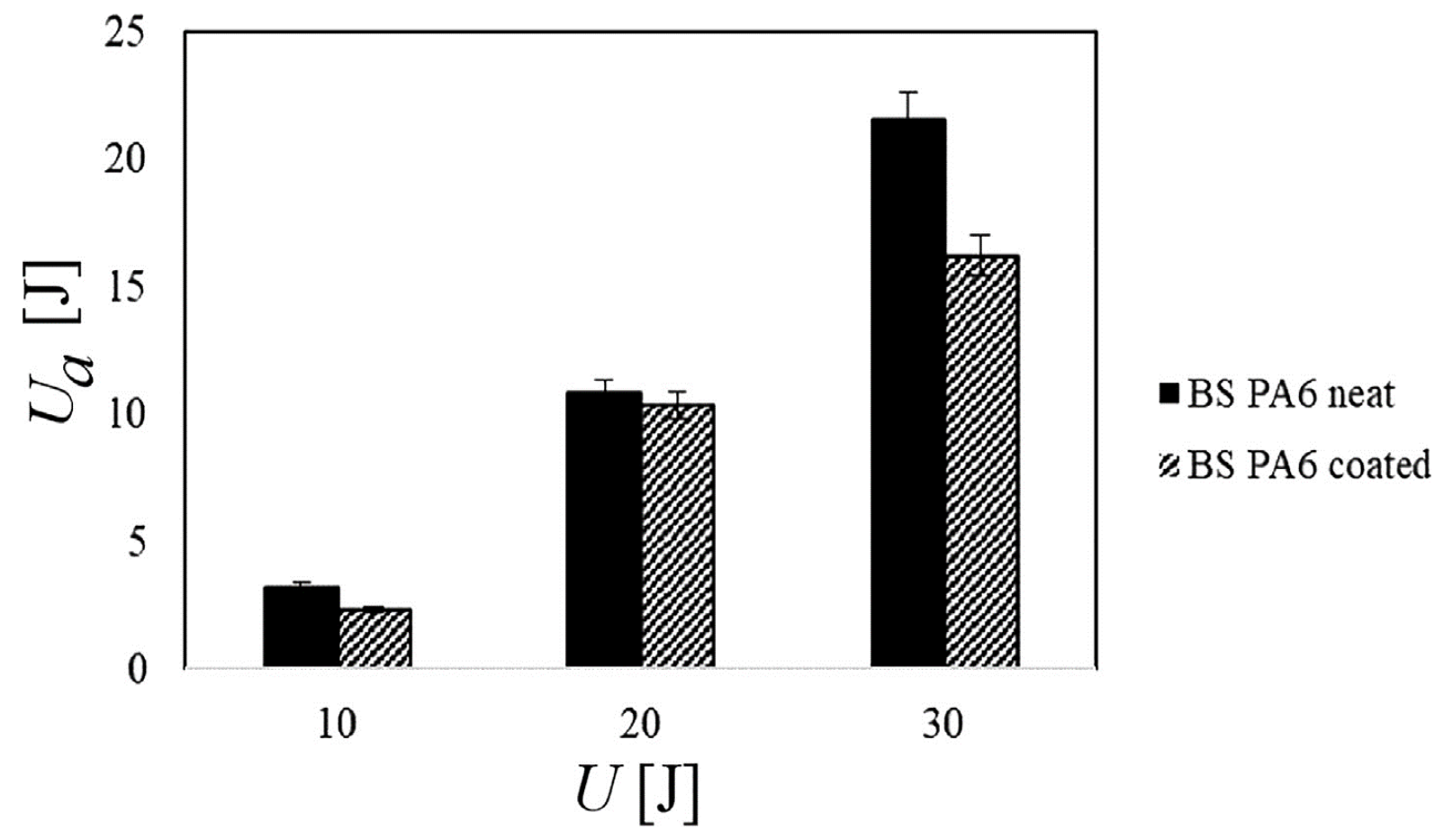

Fig. 27. Comparison of absorbed energy, $U_{a}$, versus impact energy $U$ for BS/PA6 neat and coated samples [286]

\subsection{Stitching}

An efficient method for increasing the delamination resistance of fibre-reinforced polymer composites is through-thickness stitching. In the past, several studies were proposed on the stitching of synthetic reinforced fibre composites [287,288]. However, reports on NFRC were rare [289,290]. Amongst the studies, Rong et al. [291]investigated the fracture toughness of unidirectional sisal/epoxy laminates stitched with nylon and Kevlar threads. They noticed the expansion of the fibre bridging zone improved the delamination resistance, while the tensile and flexural properties were not affected by the stitching. Fig. 28 represents the schematic view on the stitched preform of woven flax fibre-reinforced composites in which Ravandi et al. [292] observed that the laminates stitched with flax yarn and cotton thread showed right consistency and well impregnated stitched fibres. Also, they noted that flax yarn stitches showed a superior fracture toughness compared to cotton thread stitches. However, in the other studies, Ravandi and co-workers, found stitching causes a decrease of $16 \%$ in the woven flax intralaminar fracture toughness. Alternatively, a decrease of 5\% is recorded in cotton yarn stitching [293]. Even, Almansour noticed a similar result in the flax/basalt hybrid vinyl ester composites. Due to crack propagation, they pointed out that the stitching of FBVE composites significantly decreases the fracture resilience in the stitched zone than un-stitched ones. 
More recently, Li et al. [294] fabricated a novel hole arrangement- threading glue filling method to examine the mechanical characteristics of NFRP composites. The idea of this novel technique is to adjust the volume fraction, and the cross-sectional shape of the NFRP epoxy composites (refer Fig. 29). Also, adding natural fibres to epoxy caused the neutral axis to shift downwards, allowing a fair stress distribution and significantly improving the flexural properties and energy absorption capacity of NFRP epoxy composites. In other studies, Habibi et al. [295] presented a novel natural fibre reinforcement manufacturing technique by using wet lay paper making process as a replacement of stitching or weaving UD yarns. Short fibres have been used as binders to maintain cohesion between UD yarns. Habibi and co-workers note the short fibres mat layers offers a considerable increase in the transverse modulus and strength for the majority of the loading configurations. Besides, the surface of the tested specimens slowly transformed from a serrated fracture surface to a flat fracture surface with fewer matrix cracks produced on the surface of the specimen parallel to the load direction. However, a noticeable decline in longitudinal splitting and delamination with UD yarns.

Moreover, the application of stitching in the NFPC could improve the intralaminar fracture resilience and the damage tolerance. Therefore, it is vital to develop the stitching techniques in the NFPC by carefully considering the nature of fibre length, thickness and the volume of the fibre. Certain factors in the stitching may affect the impact properties of the composites due to the areal density or stitching scale. Nevertheless, the influence of stitch thickness and the stitch size could enhance the performance of the NFPC.

(a)
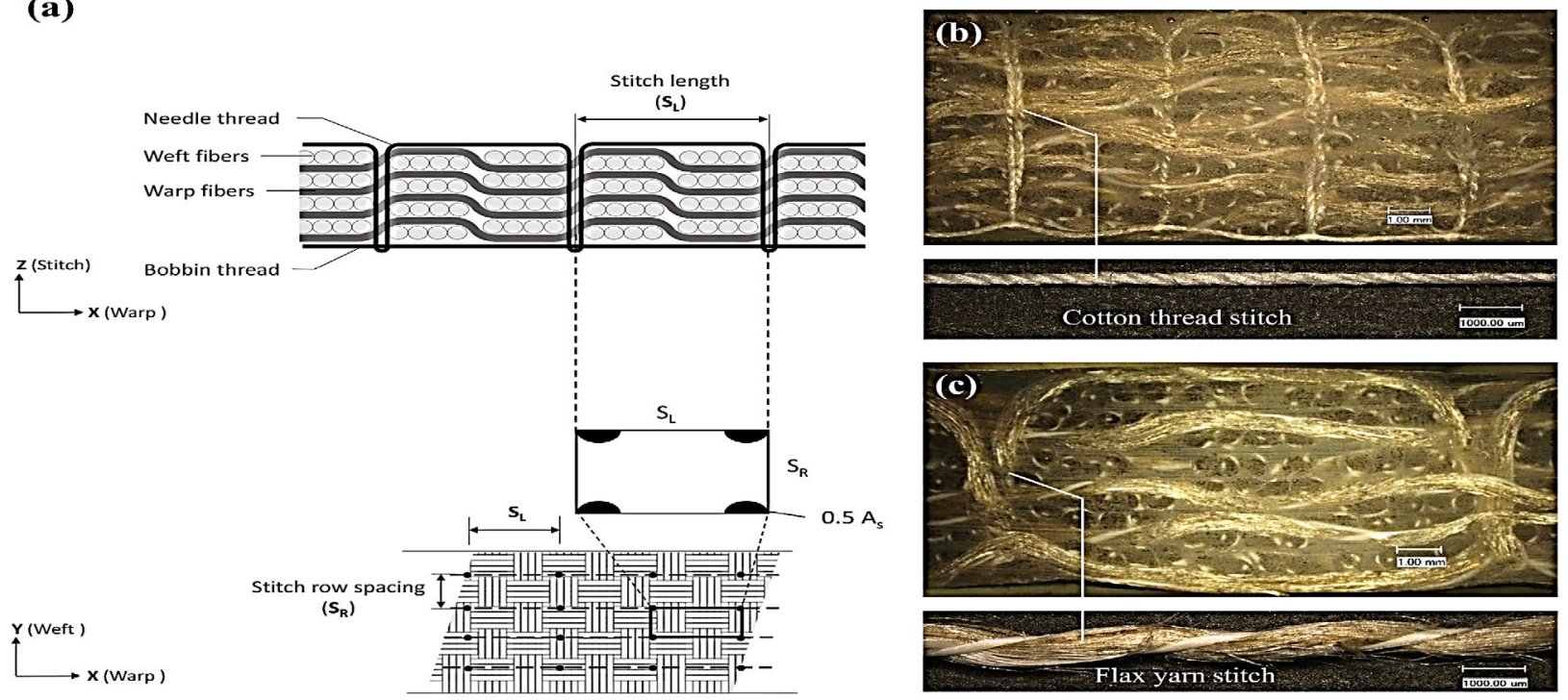

Fig. 28. (a) Schematic view of a stitched preform and definition of stitch parameters; a crosssection of (b) cotton thread, and (c) flax yarn stitched flax fibre composite [292] 


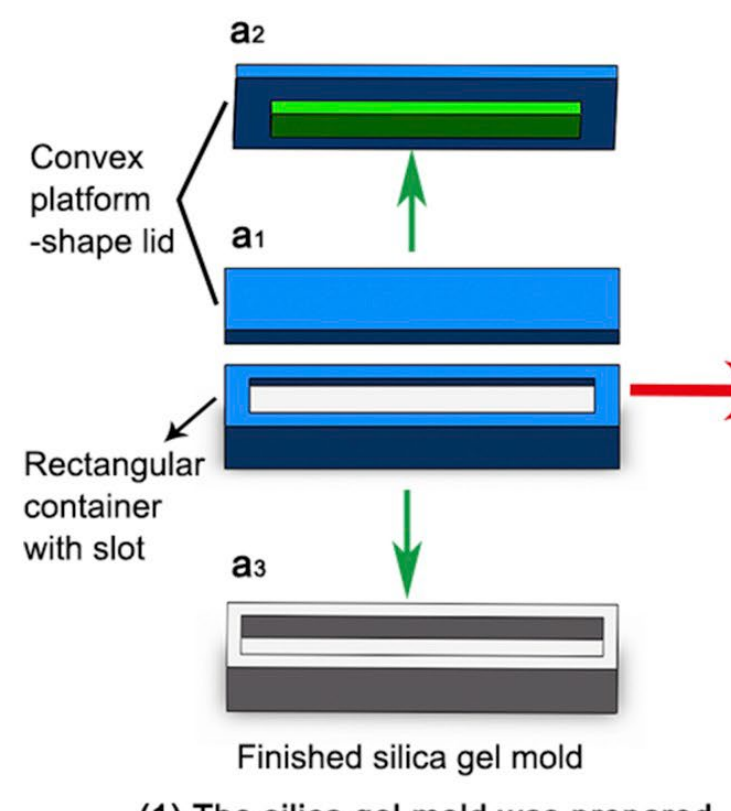

(1) The silica gel mold was prepared b2 Fiber position fixing device

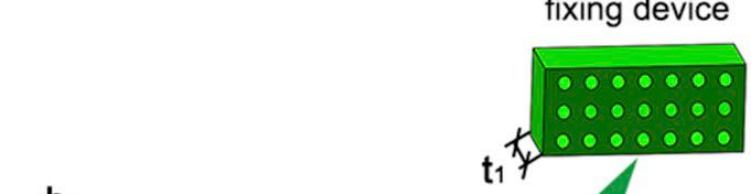

$b_{1}$

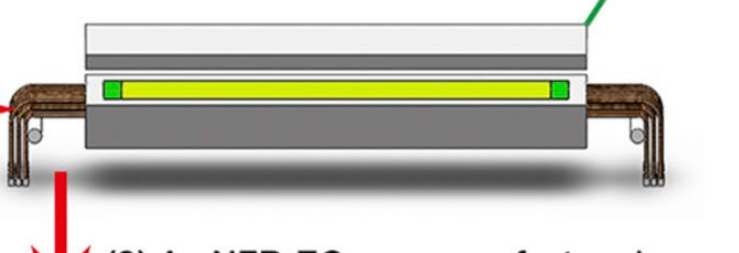

(2) An NFR-EC was manufactured

(3) A finished NFR-EC was obtained

Fig. 29. Method for manufacturing an NFR-EC [295]

\section{4. $Z$ - pinning}

Z- pinning is one of the most effective methods for enhancing composite impact resistance. This method is entirely new to the research field in the composite structures, especially for the impact test. Also, in recent studies [296], this novel technique was used in synthetic fibres to investigate Z-pinning on the composite laminates. Amongst the studies, Francesconi and Aymerich [296] found Z-pinning of carbon/epoxy prepreg laminates cannot delay the initiation and propagation of delamination damage. Nevertheless, it can improve resistance and reduces delamination size for high-speed impacts. Even Zhang and co-workers [297] noticed that this method is more useful for the thicker specimens and enhances the delamination resistance for the low-speed impacts. More recently, Hoffmann et al. [298] presented a novel technique for the integration of Z-pins in the thermoplastic reinforced composites. Ultrasonic vibrations used to insert metallic z-pins into the glass fibre reinforced polypropylene composites. While examining the mechanical properties of z-pinned thermoplastics composites, they found that there is a low pull out force, by the weak bonding and lack of friction between the steel pin and the thermoplastic polymer.

However, this method is quite challenging for natural fibres, and mostly, natural fibres are hydrophilic that affects the adhesion to a hydrophobic polymer matrix, and perhaps reduces the impact on composite material. 


\subsection{Hybrid technique}

Hybridisation techniques are superior in strengthening the composite structures and are classified into three types. (i) interply, (ii) Intraply and (iii) Fibre metal laminates shown in Fig. 30. Naik and coworkers [299] claimed that the impact strength of glass-epoxy is sensitive to the interply sequence and the modulus of the hybrid composites. In comparison with Inter -ply and Intra-ply hybrid laminates, Pegoretti et al. [300] noticed that intra-ply hybrid laminates had superior impact performances in the E-glass-poly vinyl alcohol/polyester laminates. However, Wang and coworkers [301] noticed a different observation in the basalt-aramid epoxy composites. They stated that low-velocity impact response of inter-ply composite had a more significant ductile index, with least contact force and superior specific absorption than the intraply composites. Even, Pegoretti et al. [302] noticed the same result in the E-glass poly (vinyl alcohol) hybrid composites. They depicted that crack growth was higher for intra-ply composites compared to inter-ply hybrids because the ductility index reached maximum values. Moreover, many researchers [303,304] are trying to adopt a modern hybrid technique to improve delamination resistance and crack propagation. In that, fibre metal laminates showed a promising technique to improve the fatigue crack resistance of the composite material and besides, this hybrid technique possess excellent damage tolerance characteristics compared to metallic alloys. Dhar Malingam et al. [305] studied the properties of kenaf/glass hybrid reinforced metal laminates with different fibre orientations and stacking configurations. They observed that fibre orientation $\pm 45^{\circ}$ with metal laminates showed an outstanding impact resistance in contrast to fibre orientation of $0^{\circ} / 90^{\circ}$. Also, FML with hybrid kenaf/glass composites exhibited superior characteristics in impact and tensile performance. Kaun et al. [306] stated that fibre metal laminates obey the rule of mixture approach related to tensile strength and modulus properties. They further stated that adding aluminium layers to the outer side of the basalt/flax/hemp hybrid reinforced polypropylene composites yield more considerable improvements.

Although these techniques are obtainable in the existing literature studies, it is essential to recognise the best properties for natural fibres, which can perform equally with synthetic fibres in terms of strength and rigidity. Therefore, by selecting the proper matrix reinforcement and also using alternative techniques like metal laminates combined with the natural and synthetic fibres could enhance the mechanical and impact characteristics of the ductile fibres. 

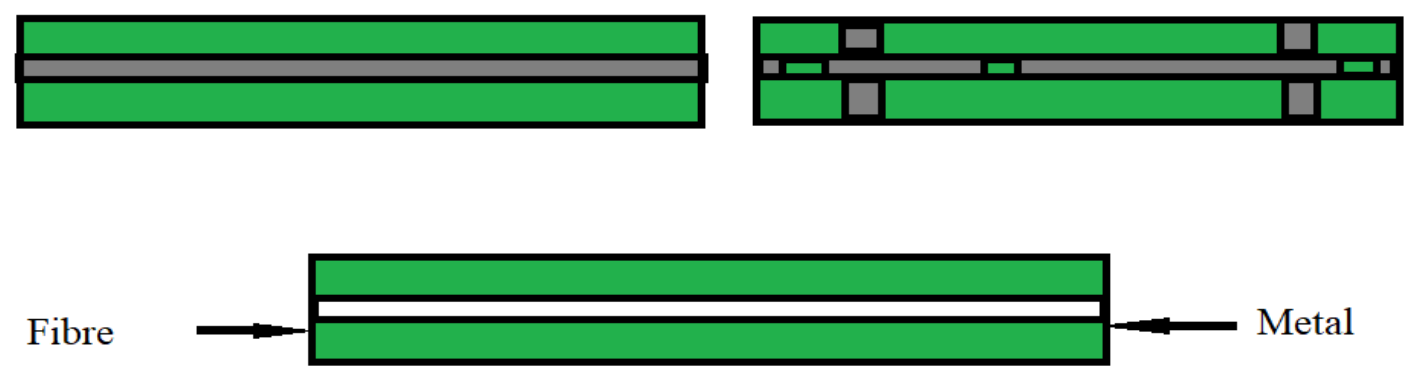

Fig. 30. Hybridisation technique (i) Inter-ply (ii) Intra-ply (iii) Fibre metal laminates, adapted by [15]

\section{Critical aspects of natural fibres exposed to different natural environments and their influence on the impact of damage characteristics.}

The various environmental factors that affect the impact damage of natural fibre composites are explained below in the following sections.

\subsection{Effect of temperature}

Temperature is a critical factor in environmental service conditions and plays a vital role in the impact of composite materials [307]. Only a few reported works on the effect of temperature and residual strength assessment for natural fibre hybrid composites subjected to low-velocity impacts. According to Suresh Kumar et al. [308], the impact damage of hemp/basalt fibres has adverse effects with an increase in temperature. Also, they observed that at $50{ }^{\circ} \mathrm{C}$, hemp and hybrid/epoxy composites performed better than the basalt/epoxy composites. At the Same Time, Mueller [309] also noticed that all composites regardless of any type of fibre showed comparable performance with a maximum impact strength in the medium temperature range. Also, there is a more or less distinctive decline in the lower and higher processing temperatures. An increased processing temperature leads to a lower viscosity and improved flowability of the binding portion. This leads to the better embedding of fibre during consolidation and thus to more excellent composite stability. However, Mueller [309] also stated that a comparatively large diameter and rough surface morphology, natural fibres often counteract free flow during the consolidation of the binder portion. Therefore, for higher shares of natural fibre, a lower binder viscosity is essential for reasonable fibre embedment. Thus, the peak value of impact strength is attained at higher temperatures (Fig. 31), and the reinforcing influence of improved fibre embedding is more prevalent over the weakening thermal decomposition. 
Shen et al. [310] noticed that moderate high temperatures could improve the impact damage of flax fibre composites. Dhakal et al. [311] investigated the temperature, and the impact response of jute fibre reinforced unsaturated polyester (UP) composites. They observed that jute/UP composites tolerate higher loads at $30^{\circ} \mathrm{C}$. David-West et al. [312] identified that there is a certain amount of plasticity seen in the after impact state of the samples at higher temperatures in natural fibre - styrene polyester matrix composites. In flax fibre composites, they noticed the sudden drop in load at temperatures tested at $40{ }^{\circ} \mathrm{C}$ and $60{ }^{\circ} \mathrm{C}$ respectively. Perhaps this could be associated with some damage by loss of stiffness and energy stored in the composites, which later may be subsequently dissipated. Singh et al. [312] investigated the effect of curing temperatures ranging from $80{ }^{\circ} \mathrm{C}$ to $130{ }^{\circ} \mathrm{C}$ on different samples of natural fibre reinforced composites. Based on the experimental results, the author found that changes in the curing temperature reduces the impact strength, but changes tensile strength and flexural strength and subsequently decreases, reaching a maximum value at $100^{\circ} \mathrm{C}$.

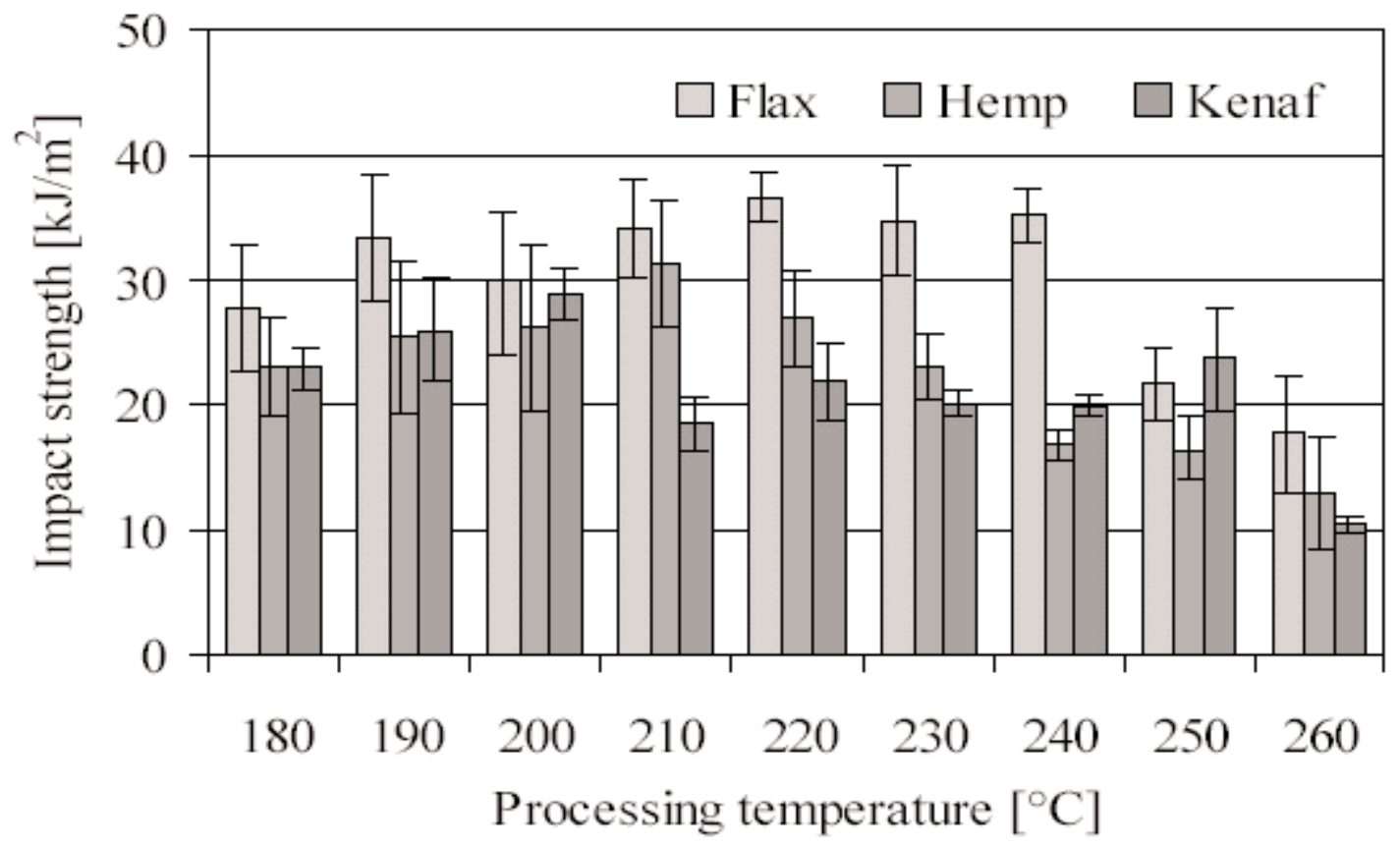

Fig. 31. Impact strength versus Temperature of composite manufacturing improved by various natural fibres [309]

\subsection{Effect of moisture absorption}

The effect of water absorption mainly depends on the particular factors such as fibre volume fraction, types of matrixes used, absorption time and temperature. Numerous works have been reported on the effects of moisture penetration related to NFPC [313-317]. Živković et al. [318] investigated the influence of basalt and flax fibre reinforced hybridised with vinyl ester 
composites. They noticed that a higher percentage of water absorbed by the flax fibre reinforced $(5.92 \%)$ compared to basalt fibre reinforced composites $(0.70 \%)$. In the case of impact tests, due to increased ductility, flax fibre showed better performance in impact resistance after accelerated ageing. On the other hand, basalt protection showed the lowest moisture intake and better residual in fibre/matrix adhesion. However, similar results were also obtained by Fiore et al.[319]. They observed that basalt layers as protection could improve the ageing resistance of flax fibre reinforced composites. More recently, Wang et al. [320] studied the hydrothermal and ageing properties of flax/carbon hybrid composites. It was observed that the water content and diffusion rate of the water molecules in the reinforced flax/carbon composites showed better performance than the flax fibre composites. Besides, the addition of carbon fibre decreases flax fibre content and provides a barrier to water molecules, enhancing FFRP's hydrothermal ageing behaviour. Dhakal et al. highlighted that the addition of carbon fibre with flax substantially reduces the amount of water absorbed [321]. Islam et al. [322] stated that the impact strength of both treated and untreated hemp-PLA composites increases due to the hygrothermal ageing is attributed to the swelling of fibre surface due to the moisture absorption, thus improving the frictional work of fibre pull-out from the PLA matrix.

\subsection{Application of natural fibres with hybrids in structural and non-structural components}

\subsection{Automotive applications}

Hybrid composites have boomed around the global market in recent years as an alternative material for conventional composites [323]. For example, the automobile industry has implemented the hybrid composites in many of the interior and exterior applications. Also, The growth of nature fibre polymer composite is humongous in engineering fields. Many wellknown automobile industries such as german auto companies (BMW, Audi groups, ford, and Mercedes), proton company, and the Cambridge industry have been using these NFPC for their production to date. Apart from automobile industries, the NFPC used in construction industries, aerospace, and windows frames [29]. Hung et al. [324] discovered the impact response of hybrid carbon/glass fibre-enhanced composites for automotive applications. They observed that a hybrid composite with carbon fibre layers on the surface would help to minimize the risk of damage, in terms of damage size and deflection subject to impact load. Likewise, in the case of natural fibres, hybridized with synthetic fibres, the authors, Loganathan et al. [325], experimented with coconut coir and glass fibre to check their unique mechanical properties under various circumstances. They reported that mechanical properties such as impact strength, 
hardness, and tensile strength showed an excellent performance in natural fibre, which will be useful for automotive and aerospace engineering.

\subsection{Military helmets}

Over the past two decades, there has been a significant increase in armour materials and designs [264]. Later, composites played a massive role in manufacturing helmets and armour materials due to lightweight in design reinforced with aramid, ultra-high molecular weight polyethylene, and other type fibres, especially in hybrid combinations [259,326,327]. Campbell \& Cramer [328] investigated a hybrid thermoplastic composite for fabricating an anti-ballistic infantry helmet. The helmet was constructed by using an inner aramid composite anti-ballistic liner and an outer-carbon fibre thermoplastic shell shown in Fig. 32. The findings of the study show potential for cycle time changes using thermoplastics, but more research will be required to increase heat transfer during pre-heating of the material before formation and to automate multiple process steps.

Recently, many researchers proposed that having natural fibres would be an added advantage in the reduction of the component's weight [329,330]. Besides, NFRP has excellent properties in impact and compression strength. Bajpai et al. [329], experimented a hybrid glass/jute/epoxy composites fabricated by using a hand-lay up method. They observed that 3-layers of glass and one layer of jute resulted in achieving a maximum impact strength pf $72.24 \mathrm{~J} / \mathrm{m}$, which can be used to replace the existing industrial safety helmets. However, Murali \& Nagarani, [330] also observed similar results in hybridizing the different types of natural fibres, stating that sisal and jute showed better performance in impact and compressive tests. Also, it possesses adequate strength in the hybrid materials and reduces half of the original weight.
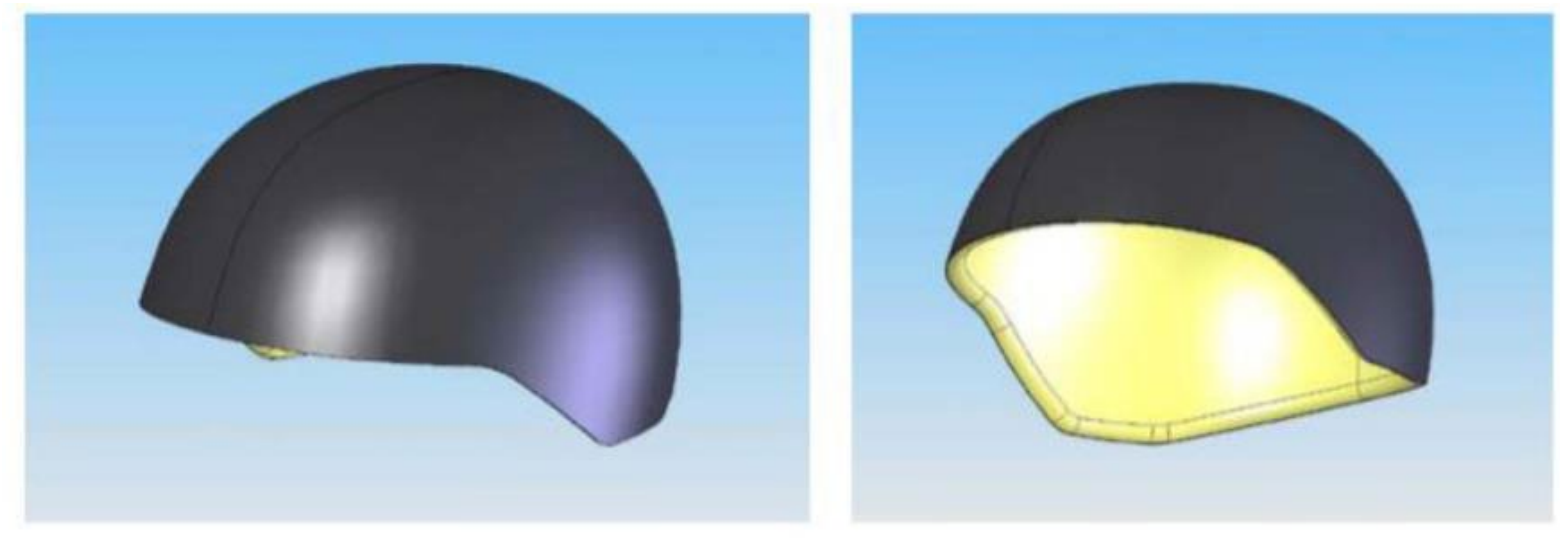

Fig. 32. Hybrid Helmet design [328] 


\subsection{Bulletproof vest}

There are many types of bulletproof vest armour plates made from different types of materials, namely steel, Kevlar, and ceramic and Ultra High Molecular Weight Poly Ethylene (UHMWPE). The development of efficient body armour for better protection against the dangerous ammunition threat has been the main goal for many researchers in this field. The continuous change in military tactics calls for the military body to undergo constant evaluation and improvement. Many experiments have been carried out to examine the efficiency of ballistic-impacted armour-plates using various types of advanced materials ranging from polymeric composites to materials such as metals, ceramics, and aerogel [331]. The paraaramid fabrics have few disadvantages in most body armours, including the large ceramic plates, which are inflexible and restricting the comfort and agility of the wearer. Therefore, to overcome these problems, liquid armours were developed, such as STF. An STF is a nonNewtonian fluid material such as "oobleck" has proven to resist impact loading significantly. There has recently been a growing interest in using this form of material as part of body armour. R, G, \& Alexander, [263] conducted a study on different types of shear thickening fluid materials made of oobleck, Polyethylene Glycol \& Silica mixture for testing the impact performance. The STF materials were sandwiched between many layers of Kevlar fabrics and manufactured and tested different types of configurations. It was discovered that the samples that contained the STF material were best in resisting penetration due to bullet impact. Besides, many researchers have started to focus on natural fibre. For instance, Da Luz et al.[326] found that even kevlar could cope with the ballistic output of an epoxy composite alongside the jute fibres. By comparing the energy absorption ratio, however, Wambua et al. [327] found that the hybrid structures have a substantial advantage over the composites of mild steel, plain flax, hemp, and jute composites. 


\section{Conclusions}

This paper highlights the various literature articles published in impact mechanics, damage tolerance of natural fibre reinforced composites. Besides this critical review, the paper has identified and discussed numerous factors for damage tolerance and impact resistance of natural fibre reinforced composites such as fibre architecture, geometry, surface treatment and novel improvement techniques. The main purpose is to highlight the numerous factors that could influence the composite's impact resilience and the challenges where the manufacturing application of composites in future could replace artificial fibres with natural fibres. Many researchers portrayed that natural fibres possess weak mechanical properties. With the existing studies, few gaps are observed that can benefit NFPC properties. Moreover, some techniques remain unresolved and challenging for further research. They are explained in the below section as follows.

1. The hybrid technique perhaps is one among the challenges for enhancing the impact characteristics of the NFPC. Though these techniques are already available, it is essential to recognize the strength and rigidity of natural fibres, which is equivalent to synthetic fibres. Therefore, the mechanical and impact strength of ductile fibres is improved by choosing the appropriate matrix reinforcement and by using alternative techniques by combining fibres with metal laminates.

2. There are numerous findings related to impact tests hybridised with synthetic fibres. Many studies suggest that STF plays a significant role in hybridising with synthetic and aramid fibres. However, studies related to STF with natural fibres is yet to be found. Moreover, STF has shown promising results in protection and flexibility. Besides, the STF with composites/fabrics still suffers several drawbacks like evaporation, leakage of carrier fluids, and air-moisture permeability. Therefore, STF evaporation will be a vital issue in the current STF research.

3. Extensive studies are done earlier on metallic coatings on metal and alloy substrates, but much less attention has been paid to polymeric substrates and composite materials. The main advantage of using 3D metal coating is to minimise the damage caused by low-speed impacts, leading to novel findings in the composite structure, for improving impact strength. However, more findings on metal coating technique with NFRPC could improve the fibre impact resistance and toughness characteristics 
4. Z- Pinning is a reliable technique to improve the impact toughness of the composites. However, it is quite challenging to predict in natural fibres as its hydrophilic nature may affect the adhesion to a hydrophobic polymer matrix, and perhaps reduces the impact on composite material.

5. Stitching in the composite could improve the intralaminar fracture toughness and the damage tolerance. Therefore, stitching technique enhancement is essential by carefully considering the fibre length, thickness, and volume. Besides, other factors in the stitching may affect the impact properties due to areal density or stitching size. However, the thickness and size of stitching could influence the improvement of the impact toughness of NFRC. 


\section{References}

[1] Swolfs Y, Gorbatikh L, Verpoest I. Fibre hybridisation in polymer composites: A review.Composites Part A: Applied Science and Manufacturing 2014;67:181-200. https://doi.org/10.1016/j.compositesa.2014.08.027.

[2] Thomason JL, Rudeiros-Fernández JL. A review of the impact performance of natural fiber thermoplastic composites. Frontiers in Materials 2018. https://doi.org/10.3389/fmats.2018.00060.

[3] Zhou G. Damage mechanisms in composite laminates impacted by a flat-ended impactor. Composites Science and Technology 1995. https://doi.org/10.1016/02663538(95)80019-0.

[4] Razali N, Sultan MTH, Mustapha F, Yidris N, Ishak MR. Impact Damage on Composite Structures - A Review. The International Journal Of Engineering And Science 2014.

[5] Asim M, Jawaid M, Saba N, Ramengmawii, Nasir M, Sultan MTH. Processing of hybrid polymer composites-a review. Hybrid Polymer Composite Materials: Processing, 2017. https://doi.org/10.1016/B978-0-08-100789-1.00001-0.

[6] Jamir MRM, Majid MSA, Khasri A. Natural lightweight hybrid composites for aircraft structural applications. Sustainable Composites for Aerospace Applications, 2018. https://doi.org/10.1016/B978-0-08-102131-6.00008-6.

[7] Dhakal HN, Zhang ZY, Bennett N, Reis PNB. Low-velocity impact response of nonwoven hemp fibre reinforced unsaturated polyester composites: Influence of impactor geometry and impact velocity. Composite Structures 2012. https://doi.org/10.1016/j.compstruct.2012.04.004.

[8] Saba N, Jawaid M. Epoxy resin based hybrid polymer composites. Hybrid Polymer Composite Materials: Properties and Characterisation, 2017. https://doi.org/10.1016/B978-0-08-100787-7.00003-2.

[9] Zhang Y, Li Y, Ma H, Yu T. Tensile and interfacial properties of unidirectional flax/glass fiber reinforced hybrid composites. Composites Science and Technology 2013;88. https://doi.org/10.1016/j.compscitech.2013.08.037. 
[10] Faruk O, Bledzki AK, Fink HP, Sain M. Biocomposites reinforced with natural fibers: 2000-2010. Progress in Polymer Science 2012. https://doi.org/10.1016/j.progpolymsci.2012.04.003.

[11] Barouni AK, Dhakal HN. Damage investigation and assessment due to low-velocity impact on flax/glass hybrid composite plates. Composite Structures 2019. https://doi.org/10.1016/j.compstruct.2019.111224.

[12] Safri SNA, Sultan MTH, Aminanda Y. Impact characterisation of Glass Fibre Reinforced Polymer (GFRP) type C-600 and E-800 using a drop weight machine. $\begin{array}{lllll}\text { Applied Mechanics and } & 2014 .\end{array}$ https://doi.org/10.4028/www.scientific.net/AMM.629.461.

[13] Safri SNA, Sultan MTH, Cardona F. Impact damage evaluation of Glass-Fiber Reinforced Polymer (GFRP) using the drop test rig - An experimental based approach. ARPN Journal of Engineering and Applied Sciences 2015;10.

[14] Suresh Kumar C, Arumugam V, Dhakal HN, John R. Effect of temperature and hybridisation on the low velocity impact behavior of hemp-basalt/epoxy composites. Composite Structures 2015;125:407-16. https://doi.org/10.1016/j.compstruct.2015.01.037.

[15] Andrew JJ, Srinivasan SM, Arockiarajan A, Dhakal HN. Parameters influencing the impact response of fiber-reinforced polymer matrix composite materials: A critical review. Composite Structures 2019. https://doi.org/10.1016/j.compstruct.2019.111007.

[16] Cantwell WJ, Morton J. The impact resistance of composite materials - a review. Composites 1991;22. https://doi.org/10.1016/0010-4361(91)90549-V.

[17] Bhat T, Chevali V, Liu X, Feih S, Mouritz AP. Fire structural resistance of basalt fibre composite. Composites Part A: Applied Science and Manufacturing 2015. https://doi.org/10.1016/j.compositesa.2015.01.006.

[18] Vieille B, Casado VM, Bouvet C. Influence of matrix toughness and ductility on the compression-after-impact behavior of woven-ply thermoplastic- and thermosettingcomposites: A comparative study. Composite Structures 2014. https://doi.org/10.1016/j.compstruct.2013.12.008. 
[19] Alcock B, Cabrera NO, Barkoula NM, Wang Z, Peijs T. The effect of temperature and strain rate on the impact performance of recyclable all-polypropylene composites. $\begin{array}{llll}\text { Composites } & \text { Part } & \text { B } & \end{array}$ https://doi.org/10.1016/j.compositesb.2007.03.003.

[20] Nur Azrie Bt Safri S, Sultan MTH, Jawaid M. Damage analysis of glass fiber reinforced composites. Durability and Life Prediction in Biocomposites, Fibre-Reinforced Composites and Hybrid Composites, 2018. https://doi.org/10.1016/B978-0-08-1022900.00007-6.

[21] Choi HY, Chang fu K. A Model for Predicting Damage in Graphite/Epoxy Laminated Composites Resulting from Low-Velocity Point Impact. Journal of Composite Materials 1992. https://doi.org/10.1177/002199839202601408.

[22] Wronkowicz-Katunin A, Dragan K. Evaluation of impact damage in composite structures using ultrasonic testing. Fatigue of Aircraft Structures 2018;2018. https://doi.org/10.2478/fas-2018-0008.

[23] Ticoalu A, Aravinthan T, Cardona F. A review of current development in natural fiber composites for structural and infrastructure applications. Southern Region Engineering Conference 2010, SREC 2010 - Incorporating the 17th Annual International Conference on Mechatronics and Machine Vision in Practice, M2VIP 2010, 2010.

[24] Jawaid M, Abdul Khalil HPS. Cellulosic/synthetic fibre reinforced polymer hybrid composites: A review. Carbohydrate Polymers 2011;86:1-18. https://doi.org/10.1016/j.carbpol.2011.04.043.

[25] Mahjoub R, Yatim JM, Mohd Sam AR, Hashemi SH. Tensile properties of kenaf fiber due to various conditions of chemical fiber surface modifications. Construction and Building Materials 2014;55:103-13. https://doi.org/10.1016/j.conbuildmat.2014.01.036.

[26] Mukhopadhyay S, Fangueiro R. Physical modification of natural fibers and thermoplastic films for composites - A review. Journal of Thermoplastic Composite Materials 2009;22. https://doi.org/10.1177/0892705708091860. 
[27] Ku H, Wang H, Pattarachaiyakoop N, Trada M. A review on the tensile properties of natural fiber reinforced polymer composites. Composites Part B: Engineering 2011;42:856-73. https://doi.org/10.1016/j.compositesb.2011.01.010.

[28] Varghese AM, Mittal V. Polymer composites with functionalized natural fibers. Biodegradable and Biocompatible Polymer Composites: Processing, Properties and Applications, 2017. https://doi.org/10.1016/B978-0-08-100970-3.00006-7.

[29] Jawaid M, Abdul Khalil HPS. Cellulosic/synthetic fibre reinforced polymer hybrid composites: A review. Carbohydrate Polymers 2011;86:1-18. https://doi.org/10.1016/j.carbpol.2011.04.043.

[30] Kumar shyam, prasad durga. ChemiCal Composition of natural fibers and its influenCe on their meChaniCal properties. 2014.

[31] Sadrmanesh V, Chen Y. Bast fibres: structure, processing, properties, and applications. $\begin{array}{llll}\text { International } & \text { Materials } & \text { Reviews }\end{array}$ https://doi.org/10.1080/09506608.2018.1501171.

[32] Terzopoulou ZN, Papageorgiou GZ, Papadopoulou E, Athanassiadou E, Alexopoulou E, Bikiaris DN. Green composites prepared from aliphatic polyesters and bast fibers. Industrial Crops and Products 2015;68. https://doi.org/10.1016/j.indcrop.2014.08.034.

[33] Gorshkova TA, Salnikov V v., Pogodina NM, Chemikosova SB, Yablokova E v., Ulanov A v., et al. Composition and distribution of cell wall phenolic compounds flax (Linum usitatissimum L.) stem tissues. Annals of Botany 2000;85. https://doi.org/10.1006/anbo.1999.1091.

[34] Zykwinska A, Thibault JF, Ralet MC. Competitive binding of pectin and xyloglucan with primary cell wall cellulose. Carbohydrate Polymers 2008;74. https://doi.org/10.1016/j.carbpol.2008.05.004.

[35] Baley C. Analysis of the flax fibres tensile behaviour and analysis of the tensile stiffness increase. Composites - Part A: Applied Science and Manufacturing 2002;33. https://doi.org/10.1016/S1359-835X(02)00040-4.

[36] Mwaikambo L. Review of the history, properties and application of plant fibres. African Journal of Science and Technology 2006. 
[37] Mwaikambo LY, Ansell MP. Mechanical properties of alkali treated plant fibres and their potential as reinforcement materials. I. hemp fibres. Journal of Materials Science 2006. https://doi.org/10.1007/s10853-006-5098-x.

[38] Ali A, Shaker K, Nawab Y, Jabbar M, Hussain T, Militky J, et al. Hydrophobic treatment of natural fibers and their composites-A review. Journal of Industrial Textiles 2018;47. https://doi.org/10.1177/1528083716654468.

[39] Bismarck A, Mishra S, Lampke T. Plant fibers as reinforcement for green composites. Natural Fibers, Biopolymers, and Biocomposites, 2005. https://doi.org/10.1201/9780203508206.ch2.

[40] Agu C v, Njoku OU, Chilaka FC, Okorie SA, Agbiogwu D. Physico-chemical Characterization of Lignocellulosic fibre from Ampelocissus cavicaulis. International Journal of Basic \& Applied Sciences IJBAS-IJENS 2012;12.

[41] Yahaya R, Jawaid M. Effect of Moisture Absorption on Mechanical Properties of Natural Fibre Hybrid Composite. 13Th International Conference on Environment, Ecosystems, and Development 2015;13.

[42] Placet V, Trivaudey F, Cisse O, Gucheret-Retel V, Boubakar ML. Diameter dependence of the apparent tensile modulus of hemp fibres: A morphological, structural or ultrastructural effect? Composites Part A: Applied Science and Manufacturing 2012;43. https://doi.org/10.1016/j.compositesa.2011.10.019.

[43] Munawar SS, Umemura K, Kawai S. Characterization of the morphological, physical, and mechanical properties of seven nonwood plant fiber bundles. Journal of Wood Science 2007;53. https://doi.org/10.1007/s10086-006-0836-x.

[44] Schäfer T, Honermeier B. Effect of sowing date and plant density on the cell morphology of hemp (Cannabis sativa L.). Industrial Crops and Products 2006;23. https://doi.org/10.1016/j.indcrop.2005.04.003.

[45] Thygesen A. General rights Properties of hemp fibre polymer composites-An optimisation of fibre properties using novel defibration methods and fibre characterisation. 2020. 
[46] Yamada J. Radiative properties of fibers with non-circular cross sectional shapes. Journal of Quantitative Spectroscopy and Radiative Transfer 2002;73. https://doi.org/10.1016/S0022-4073(01)00217-5.

[47] Baley C. Analysis of the flax fibres tensile behaviour and analysis of the tensile stiffness increase. Composites - Part A: Applied Science and Manufacturing 2002;33:939-48. https://doi.org/10.1016/S1359-835X(02)00040-4.

[48] Hu W, Ton-That MT, Perrin-Sarazin F, Denault J. An improved method for single fiber tensile test of natural fibers. Polymer Engineering and Science 2010;50. https://doi.org/10.1002/pen.21593.

[49] Andersons J, Sparniņš E, Joffe R, Wallström L. Strength distribution of elementary flax fibres. Composites Science and Technology 2005;65. https://doi.org/10.1016/j.compscitech.2004.10.001.

[50] Summerscales J, Hall W, Virk AS. A fibre diameter distribution factor (FDDF) for natural fibre composites. Journal of Materials Science 2011;46. https://doi.org/10.1007/s10853-011-5569-6.

[51] Fan M. Characterization and performance of elementary hemp fibres: Factors $\begin{array}{llll}\text { Influencing tensile } \quad \text { strength. } & \text { BioResources }\end{array}$ https://doi.org/10.15376/biores.5.4.2307-2322.

[52] Bevitori AB, da Silva ILA, Lopes FPD, Monteiro SN. Diameter dependence of tensile strength by weibull analysis: Part ii jute fiber. Revista Materia 2010;15. https://doi.org/10.1590/s1517-70762010000200005.

[53] Virk AS, Hall W, Summerscales J. Multiple Data Set (MDS) weak-link scaling analysis of jute fibres. Composites Part A: Applied Science and Manufacturing 2009;40. https://doi.org/10.1016/j.compositesa.2009.08.022.

[54] Summerscales J, Hall W, Virk AS. A fibre diameter distribution factor (FDDF) for natural fibre composites. Journal of Materials Science 2011;46. https://doi.org/10.1007/s10853-011-5569-6.

[55] Griffits AA. The phenomena of rupture and flow in solids. Masinovedenie 1995. https://doi.org/10.1098/rsta.1921.0006. 
[56] Charlet K, Baley C, Morvan C, Jernot JP, Gomina M, Bréard J. Characteristics of Hermès flax fibres as a function of their location in the stem and properties of the derived unidirectional composites. Composites Part A: Applied Science and Manufacturing 2007;38. https://doi.org/10.1016/j.compositesa.2007.03.006.

[57] Bourmaud A, Morvan C, Baley C. Importance of fiber preparation to optimize the surface and mechanical properties of unitary flax fiber. Industrial Crops and Products 2010;32. https://doi.org/10.1016/j.indcrop.2010.08.002.

[58] Munawar SS, Umemura K, Kawai S. Characterization of the morphological, physical, and mechanical properties of seven nonwood plant fiber bundles. Journal of Wood Science 2007;53. https://doi.org/10.1007/s10086-006-0836-X.

[59] Bergfjord C, Holst B. A procedure for identifying textile bast fibres using microscopy: Flax, nettle/ramie, hemp and jute. Ultramicroscopy 2010;110. https://doi.org/10.1016/j.ultramic.2010.04.014.

[60] Thygesen LG, Eder M, Burgert I. Dislocations in single hemp fibres-investigations into the relationship of structural distortions and tensile properties at the cell wall level. Journal of Materials Science 2007;42. https://doi.org/10.1007/s10853-006-1113-5.

[61] Fink HP, Walenta E, Kunze J. Structure of natural cellulosic fibres. Part 2. The supermolecular structure of bast fibres and their changes by mercerization as revealed by X-ray diffraction and 13C-NMR-spectroscopy. Papier 1999;53.

[62] Liu R, Yu H, Huang Y. Structure and morphology of cellulose in wheat straw. Cellulose 2005;12. https://doi.org/10.1023/B:CELL.0000049346.28276.95.

[63] Vignon MR, Garcia-Jaldon C, Dupeyre D. Steam explosion of woody hemp chènevotte. International Journal of Biological Macromolecules 1995;17. https://doi.org/10.1016/0141-8130(96)81852-6.

[64] Muñoz E, García-Manrique JA. Water absorption behaviour and its effect on the mechanical properties of flax fibre reinforced bioepoxy composites. International Journal of Polymer Science 2015;2015. https://doi.org/10.1155/2015/390275.

[65] Ahmad R, Hamid R, Osman SA. Physical and chemical modifications of plant fibres for reinforcement in cementitious composites. Advances in Civil Engineering 2019. https://doi.org/10.1155/2019/5185806. 
[66] Cruz J, Fangueiro R. Surface Modification of Natural Fibers: A Review. Procedia Engineering, 2016. https://doi.org/10.1016/j.proeng.2016.08.030.

[67] Trujillo EE, Osorio L, van Vuure AW, Ivens J, Verpoest I. Characterization of polymer composite materials based on bamboo fibres. 14th European conference on composite materials, 2010.

[68] Zin MH, Abdan K, Mazlan N, Zainudin ES, Liew KE. The effects of alkali treatment on the mechanical and chemical properties of pineapple leaf fibres (PALF) and adhesion to epoxy resin. IOP Conference Series: Materials Science and Engineering, vol. 368, 2018. https://doi.org/10.1088/1757-899X/368/1/012035.

[69] John MJ, Anandjiwala RD. Recent developments in chemical modification and characterization of natural fiber-reinforced composites. Polymer Composites 2008;29. https://doi.org/10.1002/pc.20461.

[70] Van de Velde K, Kiekens P. Thermoplastic polymers: Overview of several properties and their consequences in flax fibre reinforced composites. Polymer Testing 2001;20. https://doi.org/10.1016/S0142-9418(01)00017-4.

[71] Alix S, Lebrun L, Morvan C, Marais S. Study of water behaviour of chemically treated flax fibres-based composites: A way to approach the hydric interface. Composites Science and Technology 2011;71. https://doi.org/10.1016/j.compscitech.2011.02.004.

[72] Hedenberg P, Gatenholm P. Conversion of plastic/cellulose waste into composites. II. Improving adhesion between polyethylene and cellulose using ozone. Journal of Applied Polymer Science 1996;60. https://doi.org/10.1002/(SICI)10974628(19960627)60:13<2377::AID-APP9>3.0.CO;2-B.

[73] Chtourou H, Riedl B, Kokta BV. Strength properties of wood-PE composites: Influence of pulp ratio and pretreatment of PE fibers. Tappi Journal 1997;80.

[74] Uehara T, Sakata I. Effect of corona discharge treatment on cellulose prepared from beech wood. Journal of Applied Polymer Science 1990;41. https://doi.org/10.1002/app.1990.070410728.

[75] Sakata I, Morita M, Furuichi H, Kawaguchi Y. Improvement of plybond strength of paperboard by corona treatment. Journal of Applied Polymer Science 1991;42. https://doi.org/10.1002/app.1991.070420738. 
[76] Podgorski L, Roux M. Wood modification to improve the durability of coatings. JOCCA - Surface Coatings International 1999;82. https://doi.org/10.1007/BF02692672.

[77] Maldas D, Kokta B v., Daneault C. Influence of coupling agents and treatments on the mechanical properties of cellulose fiber-polystyrene composites. Journal of Applied Polymer Science 1989;37. https://doi.org/10.1002/app.1989.070370313.

[78] Sreekala MS, Kumaran MG, Joseph S, Jacob M, Thomas S. Oil palm fibre reinforced phenol formaldehyde composites: influence of fibre surface modifications on the mechanical performance. Applied Composite Materials 2000;7. https://doi.org/10.1023/A:1026534006291.

[79] Misra S, Misra M, Tripathy SS, Nayak SK, Mohanty AK. The influence of chemical surface modification on the performance of sisal-polyester biocomposites. Polymer Composites 2002;23. https://doi.org/10.1002/pc.10422.

[80] Bledzki AK, Fink HP, Specht K. Unidirectional hemp and flax EP- and PP-composites: Influence of defined fiber treatments. Journal of Applied Polymer Science 2004;93. https://doi.org/10.1002/app.20712.

[81] Samal RK, Sahoo PK, Samantaray HS. GRAFT COPOLYMERIZATION OF CELLULOSE, CELLULOSE DERIVATIVES, AND LIGNOCELLULOSE. Journal of Macromolecular Science - Reviews in Macromolecular Chemistry and Physics $1986 ; \mathrm{C} 26$.

[82] Sèbe G, Brook MA. Hydrophobization of wood surfaces: Covalent grafting of silicone $\begin{array}{llll}\text { polymers. Wood } \quad \text { Science } & \text { Technology }\end{array}$ https://doi.org/10.1007/s002260100091.

[83] Sánchez ML, Patiño W, Cárdenas J. Physical-mechanical properties of bamboo fibersreinforced biocomposites: Influence of surface treatment of fibers. Journal of Building Engineering 2020;28. https://doi.org/10.1016/j.jobe.2019.101058.

[84] Barra BN, Santos SF, Bergo PVA, Alves C, Ghavami K, Savastano H. Residual sisal fibers treated by methane cold plasma discharge for potential application in cement based material. Industrial Crops and Products 2015. https://doi.org/10.1016/j.indcrop.2015.07.052. 
[85] Valadez-Gonzalez A, Cervantes-Uc JM, Olayo R, Herrera-Franco PJ. Effect of fiber surface treatment on the fiber-matrix bond strength of natural fiber reinforced composites. Composites Part B: Engineering 1999. https://doi.org/10.1016/S13598368(98)00054-7.

[86] Jähn A, Schröder MW, Füting M, Schenzel K, Diepenbrock W. Characterization of alkali treated flax fibres by means of FT Raman spectroscopy and environmental scanning electron microscopy. Spectrochimica Acta - Part A: Molecular and Biomolecular Spectroscopy 2002. https://doi.org/10.1016/S1386-1425(01)00697-7.

[87] van de Weyenberg I, Ivens J, de Coster A, Kino B, Baetens E, Verpoest I. Influence of processing and chemical treatment of flax fibres on their composites. Composites Science and Technology 2003. https://doi.org/10.1016/S0266-3538(03)00093-9.

[88] Negawo TA, Polat Y, Buyuknalcaci FN, Kilic A, Saba N, Jawaid M. Mechanical, morphological, structural and dynamic mechanical properties of alkali treated Ensete stem fibers reinforced unsaturated polyester composites. Composite Structures 2019. https://doi.org/10.1016/j.compstruct.2018.09.043.

[89] Fiore V, di Bella G, Valenza A. The effect of alkaline treatment on mechanical properties of kenaf fibers and their epoxy composites. Composites Part B: Engineering 2015. https://doi.org/10.1016/j.compositesb.2014.08.025.

[90] Li X, Tabil LG, Panigrahi S. Chemical treatments of natural fiber for use in natural fiberreinforced composites: A review. Journal of Polymers and the Environment 2007. https://doi.org/10.1007/s10924-006-0042-3.

[91] John MJ, Francis B, Varughese KT, Thomas S. Effect of chemical modification on properties of hybrid fiber biocomposites. Composites Part A: Applied Science and Manufacturing 2008. https://doi.org/10.1016/j.compositesa.2007.10.002.

[92] Thomas MG, Abraham E, Jyotishkumar P, Maria HJ, Pothen LA, Thomas S. Nanocelluloses from jute fibers and their nanocomposites with natural rubber: Preparation and characterization. International Journal of Biological Macromolecules 2015. https://doi.org/10.1016/j.ijbiomac.2015.08.053. 
[93] Threepopnatkul P, Kaerkitcha N, Athipongarporn N. Effect of surface treatment on performance of pineapple leaf fiber-polycarbonate composites. Composites Part B: Engineering 2009. https://doi.org/10.1016/j.compositesb.2009.04.008.

[94] Gang D. The influence of surface treatment on the tensile and tribological properties of wood fiber-reinforced polyimide composite. Surface and Interface Analysis 2018. https://doi.org/10.1002/sia.6369.

[95] Liu Y, Xie J, Wu N, Wang L, Ma Y, Tong J. Influence of silane treatment on the mechanical, tribological and morphological properties of corn stalk fiber reinforced polymer composites. $\quad$ Tribology 2019. https://doi.org/10.1016/j.triboint.2018.11.004.

[96] Yao F, Wu Q, Lei Y, Guo W, Xu Y. Thermal decomposition kinetics of natural fibers: Activation energy with dynamic thermogravimetric analysis. Polymer Degradation and Stability 2008;93. https://doi.org/10.1016/j.polymdegradstab.2007.10.012.

[97] Hughes M, Carpenter J, Hill C. Deformation and fracture behaviour of flax fibre reinforced thermosetting polymer matrix composites. Journal of Materials Science 2007;42. https://doi.org/10.1007/s10853-006-1027-2.

[98] Cantero G, Arbelaiz A, Llano-Ponte R, Mondragon I. Effects of fibre treatment on wettability and mechanical behaviour of flax/polypropylene composites. Composites Science and Technology 2003;63:1247-54. https://doi.org/10.1016/S02663538(03)00094-0.

[99] Zin MH, Abdan K, Mazlan N, Zainudin ES, Liew KE. The effects of alkali treatment on the mechanical and chemical properties of pineapple leaf fibres (PALF) and adhesion to epoxy resin. IOP Conference Series: Materials Science and Engineering, vol. 368, 2018. https://doi.org/10.1088/1757-899X/368/1/012035.

[100] Chtourou H, Riedl B, Kokta BV. Strength properties of wood-PE composites: Influence of pulp ratio and pretreatment of PE fibers. Tappi Journal 1997;80.

[101] Maldas D, Kokta B v., Daneault C. Influence of coupling agents and treatments on the mechanical properties of cellulose fiber-polystyrene composites. Journal of Applied Polymer Science 1989;37. https://doi.org/10.1002/app.1989.070370313. 
[102] Alix S, Lebrun L, Morvan C, Marais S. Study of water behaviour of chemically treated flax fibres-based composites: A way to approach the hydric interface. Composites Science and Technology 2011;71. https://doi.org/10.1016/j.compscitech.2011.02.004.

[103] Arifuzzaman Khan GM, Shaheruzzaman M, Rahman MH, Abdur Razzaque SM, Islam MS, Alam MS. Surface modification of okra bast fiber and its physico-chemical characteristics. Fibers and Polymers 2009;10. https://doi.org/10.1007/s12221-0090065-1.

[104] Agarwal J, Sahoo S, Mohanty S, Nayak SK. Progress of novel techniques for lightweight automobile applications through innovative eco-friendly composite materials: A review. $\begin{array}{llll}\text { Journal of Thermoplastic Composite } & \text { Materials }\end{array}$ https://doi.org/10.1177/0892705718815530.

[105] Holbery J, Houston D. Natural-fiber-reinforced polymer composites in automotive applications. JOM 2006. https://doi.org/10.1007/s11837-006-0234-2.

[106] Park G, Park H. Structural design and test of automobile bonnet with natural flax composite through impact damage analysis. Composite Structures 2018. https://doi.org/10.1016/j.compstruct.2017.10.068.

[107] Wang B, Sain M, Oksman K. Study of structural morphology of hemp fiber from the micro to the nanoscale. Applied Composite Materials 2007. https://doi.org/10.1007/s10443-006-9032-9.

[108] Malkapuram R, Kumar V, Singh Negi Y. Recent development in natural fiber reinforced polypropylene composites. Journal of Reinforced Plastics and Composites 2009. https://doi.org/10.1177/0731684407087759.

[109] Farah S, Anderson DG, Langer R. Physical and mechanical properties of PLA, and their functions in widespread applications - A comprehensive review. Advanced Drug Delivery Reviews 2016. https://doi.org/10.1016/j.addr.2016.06.012.

[110] Malkapuram R, Kumar V, Singh Negi Y. Recent development in natural fiber reinforced polypropylene composites. Journal of Reinforced Plastics and Composites 2009. https://doi.org/10.1177/0731684407087759. 
[111] Kandemir A, Pozegic TR, Hamerton I, Eichhorn SJ, Longana ML. Characterisation of natural fibres for sustainable discontinuous fibre composite materials. Materials 2020;13. https://doi.org/10.3390/ma13092129.

[112] Ahmad F, Choi HS, Park MK. A review: Natural fiber composites selection in view of mechanical, light weight, and economic properties. Macromolecular Materials and Engineering 2015;300. https://doi.org/10.1002/mame.201400089.

[113] Thyavihalli Girijappa YG, Mavinkere Rangappa S, Parameswaranpillai J, Siengchin S. Natural Fibers as Sustainable and Renewable Resource for Development of EcoFriendly Composites: A Comprehensive Review. Frontiers in Materials 2019;6. https://doi.org/10.3389/fmats.2019.00226.

[114] Sreekala MS, Thomas S. Effect of fibre surface modification on water-sorption characteristics of oil palm fibres. Composites Science and Technology 2003;63. https://doi.org/10.1016/S0266-3538(02)00270-1.

[115] Thakur VK, Thakur MK, Gupta RK. Review: Raw Natural Fiber-Based Polymer Composites. International Journal of Polymer Analysis and Characterization 2014;19. https://doi.org/10.1080/1023666X.2014.880016.

[116] Oksman K, Aitomäki Y, Mathew AP, Siqueira G, Zhou Q, Butylina S, et al. Review of the recent developments in cellulose nanocomposite processing. Composites Part A: $\begin{array}{llll}\text { Applied } & \text { Science } & \text { and }\end{array}$ https://doi.org/10.1016/j.compositesa.2015.10.041.

[117] Kabir MM, Wang H, Aravinthan T, Cardona F, Lau K-T. Effects of Natural Fibre Surface on Composite Properties : a Review. Energy, Environment and Sustainability 2007.

[118] Ku H, Cheng YM, Snook C, Baddeley D. Drop weight impact test fracture of vinyl ester composites: Micrographs of pilot study. Journal of Composite Materials 2005. https://doi.org/10.1177/0021998305051111.

[119] Ahmad I, Baharum A, Abdullah I. Effect of extrusion rate and fiber loading on mechanical properties of twaron Fiber-Thermoplastic Natural Rubber (TPNR) composites. Journal of Reinforced Plastics and Composites 2006. https://doi.org/10.1177/0731684406065082. 
[120] Safri SNA, Sultan MTH, Jawaid M, Jayakrishna K. Impact behaviour of hybrid composites for structural applications: A review. Composites Part B: Engineering 2018;133:112-21. https://doi.org/10.1016/j.compositesb.2017.09.008.

[121] Nabi Saheb D, Jog JP. Natural fiber polymer composites: A review. Advances in Polymer Technology $\quad 1999 . \quad$ https://doi.org/10.1002/(SICI)10982329(199924)18:4<351::AID-ADV6>3.0.CO;2-X.

[122] Wambua P, Ivens J, Verpoest I. Natural fibres: Can they replace glass in fibre reinforced plastics? Composites Science and Technology 2003. https://doi.org/10.1016/S02663538(03)00096-4.

[123] Wallenberger FT, Watson JC, Li H. Glass Fibers. 2001.

[124] Muralidhara B, Kumaresh Babu SP, Suresha B. Utilizing vacuum bagging process to prepare carbon fiber/epoxy composites with improved mechanical properties. Materials Today: Proceedings 2019. https://doi.org/10.1016/j.matpr.2019.09.051.

[125] Jassal M, Ghosh S. Aramid fibres - An overview. Indian Journal of Fibre and Textile Research 2002.

[126] Yang HH. Kevlar aramid fibre. 1993. https://doi.org/10.1016/0261-3069(93)90147-n.

[127] Zych T, Wojciech K. Study on the properties of cement mortars with basalt fibres. Brittle Matrix Composites 10, 2012. https://doi.org/10.1016/B978-0-85709-9884.50015-3.

[128] Reeder J. A Bilinear Failure Criterion for Mixed-Mode Delamination. Eleventh Volume: Composite Materials_-Testing and Design, 2009. https://doi.org/10.1520/stp12636s.

[129] Laffan MJ. Testing the toughness of polymer matrix composites. Failure Mechanisms in Polymer Matrix Composites: Criteria, Testing and Industrial Applications, 2012. https://doi.org/10.1016/B978-1-84569-750-1.50005-7.

[130] Nasuha N, Azmi AI, Tan CL. A review on mode-I interlaminar fracture toughness of fibre reinforced composites. Journal of Physics: Conference Series, vol. 908, Institute of Physics Publishing; 2017. https://doi.org/10.1088/1742-6596/908/1/012024. 
[131] Ramamurty U. Mechanical Testing Methods of Fibers and Composites. Encyclopedia of Materials: Science and Technology, 2001. https://doi.org/10.1016/b0-08-0431526/00920-7.

[132] Caprino G. The use of thin DCB specimens for measuring mode I interlaminar fracture toughness of composite materials. Composites Science and Technology 1990. https://doi.org/10.1016/0266-3538(90)90052-7.

[133] Prasad MSS, Venkatesha CS, Jayaraju T. Experimental Methods of Determining Fracture Toughness of Fiber Reinforced Polymer Composites under Various Loading Conditions. Journal of Minerals and Materials Characterization and Engineering 2011. https://doi.org/10.4236/jmmce.2011.1013099.

[134] Almansour FA, Dhakal HN, Zhang ZY. Effect of water absorption on Mode I interlaminar fracture toughness of flax/basalt reinforced vinyl ester hybrid composites. Composite Structures 2017;168:813-25. https://doi.org/10.1016/j.compstruct.2017.02.081.

[135] Bensadoun F, Verpoest I, van Vuure AW. Interlaminar fracture toughness of flax-epoxy composites. Journal of Reinforced Plastics and Composites 2017;36:121-36. https://doi.org/10.1177/0731684416672925.

[136] Zulkifli R, Azhari CH, Ghazali MJ, Ismail AR, Sulong AB. Interlaminar fracture toughness of multi-layer woven silk/epoxy composites treated with coupling agent. European Journal of Scientific Research 2009.

[137] Ferreira De Moura MFS. Interlaminar mode II fracture Characterization. Delamination Behaviour of Composites: A volume in Woodhead Publishing Series in Composites Science and Engineering, 2008. https://doi.org/10.1533/9781845694821.3.310.

[138] Blackman BRK, Brunner AJ, Williams JG. Mode II fracture testing of composites: a new look at an old problem. Engineering Fracture Mechanics 2006;73:2443-55. https://doi.org/10.1016/j.engfracmech.2006.05.022.

[139] Russell AJ, Street KN. FACTORS AFFECTING THE INTERLAMINAR FRACTURE ENERGY OF GRAPHITE/EPOXY LAMINATES., 1982. 
[140] Feng NL, Malingam SD, Irulappasamy S. Bolted joint behavior of hybrid composites. Failure Analysis in Biocomposites, Fibre-Reinforced Composites and Hybrid Composites, 2018. https://doi.org/10.1016/B978-0-08-102293-1.00004-8.

[141] Nunna S, Chandra PR, Shrivastava S, Jalan AK. A review on mechanical behavior of natural fiber based hybrid composites. Journal of Reinforced Plastics and Composites 2012. https://doi.org/10.1177/0731684412444325.

[142] Mochane MJ, Mokhena TC, Mokhothu TH, Mtibe A, Sadiku ER, Ray SS, et al. Recent progress on natural fiber hybrid composites for advanced applications: A review. Express Polymer Letters 2019. https://doi.org/10.3144/expresspolymlett.2019.15.

[143] Gururaja MN, Rao H. A Review on Recent Applications and Future Prospectus of Hybrid Composites. International Journal of Soft Computing and Engineering 2012.

[144] Shahzad A. Hemp fiber and its composites - A review. Journal of Composite Materials 2012. https://doi.org/10.1177/0021998311413623.

[145] Karakoti A, Tripathy P, Kar VR, Jayakrishnan K, Rajesh M, Manikandan M. Finite element modeling of natural fiber-based hybrid composites. Modelling of Damage Processes in Biocomposites, Fibre-Reinforced Composites and Hybrid Composites, 2018. https://doi.org/10.1016/B978-0-08-102289-4.00001-1.

[146] Shahzad A. Impact and fatigue properties of hemp-glass fiber hybrid biocomposites. Journal of Reinforced Plastics and Composites 2011. https://doi.org/10.1177/0731684411425975.

[147] Saidane EH, Scida D, Pac MJ, Ayad R. Mode-I interlaminar fracture toughness of flax, glass and hybrid flax-glass fibre woven composites: Failure mechanism evaluation using acoustic emission analysis. Polymer Testing 2019;75:246-53. https://doi.org/10.1016/j.polymertesting.2019.02.022.

[148] Zhang Y, Li Y, Ma H, Yu T. Tensile and interfacial properties of unidirectional flax/glass fiber reinforced hybrid composites. Composites Science and Technology 2013;88:172-7. https://doi.org/10.1016/j.compscitech.2013.08.037.

[149] Jung H, Kim Y. Mode I fracture toughness of carbon-glass/epoxy interply hybrid composites. Journal of Mechanical Science and Technology 2015;29:1955-62. https://doi.org/10.1007/s12206-015-0416-3. 
[150] Zhao Y, Cao M, Lum WP, Tan VBC, Tay TE. Interlaminar fracture toughness of hybrid woven carbon-Dyneema composites. Composites Part A: Applied Science and Manufacturing 2018. https://doi.org/10.1016/j.compositesa.2018.08.035.

[151] Almansour FA, Dhakal HN, Zhang ZY. Investigation into Mode II interlaminar fracture toughness characteristics of flax/basalt reinforced vinyl ester hybrid composites. $\begin{array}{llll}\text { Composites } & \text { Science } & \text { Technology }\end{array}$ https://doi.org/10.1016/j.compscitech.2017.11.016.

[152] Audibert C, Andreani AS, Lainé É, Grandidier JC. Mechanical characterization and damage mechanism of a new flax-Kevlar hybrid/epoxy composite. Composite Structures 2018. https://doi.org/10.1016/j.compstruct.2018.04.061.

[153] Salman SD, Sharba MJ, Leman Z, Sultan MTH, Ishak MR, Cardona F. Hybrid composites failure. vol. 11. 2016.

[154] Zhou HX, Li SP, Xie K, Lu X, Zhao Y, Tay TE. Mode II interlaminar fracture of hybrid woven carbon-Dyneema composites. Composites Part A: Applied Science and Manufacturing 2020;131. https://doi.org/10.1016/j.compositesa.2020.105785.

[155] Custódio J, Cabral-Fonseca S. Advanced fibre-reinforced polymer (FRP) composites for structural applications: 22. Advanced fibre-reinforced polymer (FRP) composites for the rehabilitation. 2013.

[156] J. Shesan O, C. Stephen A, G. Chioma A, Neerish R, E. Rotimi S. Improving the Mechanical Properties of Natural Fiber Composites for Structural and Biomedical Applications. Renewable and Sustainable Composites, 2019. https://doi.org/10.5772/intechopen.85252.

[157] Bar M, Alagirusamy R, Das A. Properties of flax-polypropylene composites made through hybrid yarn and film stacking methods. Composite Structures 2018. https://doi.org/10.1016/j.compstruct.2018.04.078.

[158] George J, Ivens J, Verpoest I. Mechanical properties of flax fibre reinforced epoxy composites. Angewandte Makromolekulare Chemie 1999. https://doi.org/10.1002/(SICI)1522-9505(19991201)272:1<41::AID-

APMC41>3.0.CO;2-X. 
[159] Kabir MM, Wang H, Lau KT, Cardona F. Chemical treatments on plant-based natural fibre reinforced polymer composites: An overview. Composites Part B: Engineering 2012;43. https://doi.org/10.1016/j.compositesb.2012.04.053.

[160] Bhattacharyya Engineering Biopolymers Stoyko Fakirov Debes Bhattacharyya Fakirov F, Engineering Biopolymers B, Hanser Verlag wwwhanserde C. Engineering Biopolymers Handbook of Homopolymers, Blends, and Composites. n.d.

[161] Joseph PV. Studies on short Sisal fibre reinforced isotactic Polypropylene Composites 2001.

[162] Ku H, Wang H, Pattarachaiyakoop N, Trada M. A review on the tensile properties of natural fiber reinforced polymer composites. Composites Part B: Engineering 2011;42. https://doi.org/10.1016/j.compositesb.2011.01.010.

[163] Ahmad I, Baharum A, Abdullah I. Effect of extrusion rate and fiber loading on mechanical properties of twaron Fiber-Thermoplastic Natural Rubber (TPNR) composites. Journal of Reinforced Plastics and Composites 2006;25. https://doi.org/10.1177/0731684406065082.

[164] Santulli C, Caruso AP. Effect of fibre architecture on the falling weight impact properties of hemp/epoxy composites. Journal of Biobased Materials and Bioenergy 2009;3. https://doi.org/10.1166/jbmb.2009.1037.

[165] Fragassa C, Santulli C, Pavlovi A, Šljivi M. IMPROVING PERFORMANCE AND APPLICABILITY OF GREEN COMPOSITE MATERIALS BY HYBRIDIZATION n.d. https://doi.org/10.7251/COMEN1501035F.

[166] Dhakal HN, Zhang ZY, Richardson MOW, Errajhi OAZ. The low velocity impact response of non-woven hemp fibre reinforced unsaturated polyester composites. Composite Structures 2007;81. https://doi.org/10.1016/j.compstruct.2006.10.003.

[167] Bensadoun F, Depuydt D, Baets J, van Vuure AW, Verpoest I. Influence of fibre architecture on impact and fatigue behaviour of flax fibre-based composites. ICCM International Conferences on Composite Materials, vol. 2013- July, 2013.

[168] Awais H, Nawab Y, Anjang A, Md Akil H, Zainol Abidin MS. Effect of fabric architecture on the shear and impact properties of natural fibre reinforced composites. 
$\begin{array}{llll}\text { Composites } & \text { Part } & \text { B } & \text { Engineering }\end{array}$ https://doi.org/10.1016/j.compositesb.2020.108069.

[169] Lebaupin Y, Hoang TQT, Chauvin M, Touchard F. Influence of the stacking sequence on the low-energy impact resistance of flax/PA11 composite. Journal of Composite Materials 2019;53. https://doi.org/10.1177/0021998319837339.

[170] Muralidhar BA, Giridev VR, Raghunathan K. Flexural and impact properties of flax woven, knitted and sequentially stacked knitted/woven preform reinforced epoxy composites. Journal of Reinforced Plastics and Composites 2012;31. https://doi.org/10.1177/0731684412437987.

[171] Kannan TG, Wu CM, Cheng KB, Wang CY. Effect of reinforcement on the mechanical and thermal properties of flax/polypropylene interwoven fabric composites. Journal of Industrial Textiles 2013;42. https://doi.org/10.1177/1528083712442695.

[172] Evci C. Thickness-dependent energy dissipation characteristics of laminated composites subjected to low velocity impact. Composite Structures 2015;133. https://doi.org/10.1016/j.compstruct.2015.07.111.

[173] Wang W, Chouw N, Jayaraman K. Effect of thickness on the impact resistance of flax fibre-reinforced polymer. Journal of Reinforced Plastics and Composites 2016;35. https://doi.org/10.1177/0731684416648780.

[174] Dhakal HN, Skrifvars M, Adekunle K, Zhang ZY. Falling weight impact response of jute/methacrylated soybean oil bio-composites under low velocity impact loading. $\begin{array}{llll}\text { Composites } \quad \text { Science } & \text { 2014;92. }\end{array}$ https://doi.org/10.1016/j.compscitech.2013.12.014.

[175] Zaman I, Emran Ismail A, Khairudin Awang M. Influence of Fiber Volume Fraction on the Tensile Properties and Dynamic Characteristics of Coconut Fiber Reinforced Composite. n.d.

[176] Singleton ACN, Baillie CA, Beaumont PWR, Peijs T. On the mechanical properties, deformation and fracture of a natural fibre/recycled polymer composite. Composites Part B: Engineering 2003;34. https://doi.org/10.1016/S1359-8368(03)00042-8. 
[177] Garkhail SK, Heijenrath RWH, Peijs T. Mechanical properties of natural-fibre-matreinforced thermoplastics based on flax fibres and polypropylene. Applied Composite Materials 2000;7. https://doi.org/10.1023/A:1026590124038.

[178] Bax B, Müssig J. Impact and tensile properties of PLA/Cordenka and PLA/flax composites. Composites $\quad$ Science and Technology 2008;68. https://doi.org/10.1016/j.compscitech.2008.01.004.

[179] Escalante-Solís MA, Valadez-González A, Herrera-Franco PJ. A note on the effect of the fiber curvature on the micromechanical behavior of natural fiber reinforced thermoplastic composites. Express Polymer Letters 2015;9. https://doi.org/10.3144/expresspolymlett.2015.100.

[180] van Hattum FWJ, Bernardo CA. Model to predict the strength of short fiber composites. Polymer Composites 1999;20. https://doi.org/10.1002/pc.10376.

[181] Venkateshwaran N, Elayaperumal A. Modeling and evaluation of tensile properties of randomly oriented banana/epoxy composite. Journal of Reinforced Plastics and Composites 2011;30. https://doi.org/10.1177/0731684411430559.

[182] Ularych F, Sova M, Vokrouhlec??y J, Turčić B. Empirical relations of the mechanical properties of polyamide 6 reinforced with short glass fibers. Polymer Composites 1993;14:229-37. https://doi.org/10.1002/pc.750140308.

[183] Tucker CL, Liang E. Stiffness predictions for unidirectional short-fiber composites: Review and evaluation. Composites Science and Technology 1999;59. https://doi.org/10.1016/S0266-3538(98)00120-1.

[184] Saghafi H, Minak G, Zucchelli A. Effect of preload on the impact response of curved composite panels. Composites Part B: Engineering 2014;60. https://doi.org/10.1016/j.compositesb.2013.12.026.

[185] Lee SM, Cheon JS, Im YT. Experimental and numerical study of the impact behavior of SMC plates. Composite Structures, 1999. https://doi.org/10.1016/S02638223(00)00021-0.

[186] Zhou G, Lloyd JC, McGuirk JJ. Experimental evaluation of geometric factors affecting damage mechanisms in carbon/epoxy plates. Composites Part A: Applied Science and Manufacturing 2001. https://doi.org/10.1016/S1359-835X(00)00119-6. 
[187] Mines RAW, Roach AM, Jones N. High velocity perforation behaviour of polymer composite laminates. International Journal of Impact Engineering 1999. https://doi.org/10.1016/S0734-743X(99)00019-6.

[188] Ambur DR, Kemmerly HL. Influence of impactor mass on the damage characteristics and failure strength of laminated composite plates. Collection of Technical Papers AIAA/ASME/ASCE/AHS/ASC Structures, Structural Dynamics and Materials Conference, 1998. https://doi.org/10.2514/6.1998-1784.

[189] Bucinell R, Nuismer R, Koury J. Response of Composite Plates to Quasi-Static Impact Events. Composite Materials: Fatigue and Fracture (Third Volume), 2009. https://doi.org/10.1520/stp17735s.

[190] Giurgiutiu V. Damage and Failure of Aerospace Composites. Structural Health Monitoring of Aerospace Composites, 2016. https://doi.org/10.1016/b978-0-12409605-9.00005-2.

[191] Couture A, Lebrun G, Laperrière L. Mechanical properties of polylactic acid (PLA) composites reinforced with unidirectional flax and flax-paper layers. Composite Structures 2016. https://doi.org/10.1016/j.compstruct.2016.07.069.

[192] Sathish S, Kumaresan K, Prabhu L, Gokulkumar S. Experimental investigation of mechanical and ftir analysis of flax fiber/epoxy composites incorporating sic, $\mathrm{A} 12 \mathrm{O} 3$ and graphite. Revista Romana de Materiale/ Romanian Journal of Materials 2018.

[193] Sair S, Oushabi A, Kammouni A, Tanane O, Abboud Y, el Bouari A. Mechanical and thermal conductivity properties of hemp fiber reinforced polyurethane composites. Case Studies in Construction Materials 2018. https://doi.org/10.1016/j.cscm.2018.02.001.

[194] Haghighatnia T, Abbasian A, Morshedian J. Hemp fiber reinforced thermoplastic polyurethane composite: An investigation in mechanical properties. Industrial Crops and Products 2017. https://doi.org/10.1016/j.indcrop.2017.07.020.

[195] Lu N, Oza S. A comparative study of the mechanical properties of hemp fiber with virgin and recycled high density polyethylene matrix. Composites Part B: Engineering 2013. https://doi.org/10.1016/j.compositesb.2012.09.076.

[196] Neves ACC, Rohen LA, Mantovani DP, Carvalho JPRG, Vieira CMF, Lopes FPD, et al. Comparative mechanical properties between biocomposites of Epoxy and polyester 
matrices reinforced by hemp fiber. Journal of Materials Research and Technology 2019. https://doi.org/10.1016/j.jmrt.2019.11.056.

[197] Akhtar MN, Sulong AB, Radzi MKF, Ismail NF, Raza MR, Muhamad N, et al. Influence of alkaline treatment and fiber loading on the physical and mechanical properties of kenaf/polypropylene composites for variety of applications. Progress in Natural Science: Materials International 2016;26:657-64. https://doi.org/10.1016/j.pnsc.2016.12.004.

[198] Abu Bakar MA, Ahmad S, Kuntjoro W. The mechanical properties of treated and untreated kenaf fibre reinforced epoxy composite. Journal of Biobased Materials and Bioenergy, vol. 4, 2010, p. 159-63. https://doi.org/10.1166/jbmb.2010.1080.

[199] Mochane MJ, Mokhena TC, Mokhothu TH, Mtibe A, Sadiku ER, Ray SS, et al. Recent progress on natural fiber hybrid composites for advanced applications: A review. Express Polymer Letters 2019;13. https://doi.org/10.3144/expresspolymlett.2019.15.

[200] Nisini E, Santulli C, Liverani A. Mechanical and impact characterization of hybrid composite laminates with carbon, basalt and flax fibres. Composites Part B: Engineering 2017;127. https://doi.org/10.1016/j.compositesb.2016.06.071.

[201] Singha K. A Short Review on Basalt Fiber. International Journal of Textile Science 2012;1. https://doi.org/10.5923/j.textile.20120104.02.

[202] Fragassa C, Pavlovic A, Santulli C. Mechanical and impact characterisation of flax and basalt fibre vinylester composites and their hybrids. Composites Part B: Engineering 2018;137:247-59. https://doi.org/10.1016/j.compositesb.2017.01.004.

[203] Petrucci R, Santulli C, Puglia D, Sarasini F, Torre L, Kenny JM. Mechanical characterisation of hybrid composite laminates based on basalt fibres in combination with flax, hemp and glass fibres manufactured by vacuum infusion. Materials and Design 2013. https://doi.org/10.1016/j.matdes.2013.02.014.

[204] Akil HM, Santulli C, Sarasini F, Tirillò J, Valente T. Environmental effects on the mechanical behaviour of pultruded jute/glass fibre-reinforced polyester hybrid composites. Composites Science and Technology 2014;94. https://doi.org/10.1016/j.compscitech.2014.01.017. 
[205] Ramana MV, Ramprasad S. Experimental Investigation on Jute/Carbon Fibre reinforced Epoxy based Hybrid Composites. Materials Today: Proceedings, vol. 4, 2017. https://doi.org/10.1016/j.matpr.2017.07.214.

[206] Kureemun U, Ravandi M, Tran LQN, Teo WS, Tay TE, Lee HP. Effects of hybridization and hybrid fibre dispersion on the mechanical properties of woven flax-carbon epoxy at low carbon fibre volume fractions. Composites Part B: Engineering 2018;134. https://doi.org/10.1016/j.compositesb.2017.09.035.

[207] Maslinda AB, Abdul Majid MS, Ridzuan MJM, Afendi M, Gibson AG. Effect of water absorption on the mechanical properties of hybrid interwoven cellulosic-cellulosic fibre reinforced epoxy composites. Composite Structures 2017;167. https://doi.org/10.1016/j.compstruct.2017.02.023.

[208] Akash, Venkatesha Gupta NS, Sreenivas Rao K v. An Experimental Study on Sisal/Hemp Fiber Reinforced Hybrid Composites. Materials Today: Proceedings, vol. 5, 2018. https://doi.org/10.1016/j.matpr.2017.11.408.

[209] Naidu AL, Kona S. Experimental study of the mechanical properties of banana fiber and groundnut shell ash reinforced epoxy hybrid composite. International Journal of Engineering, Transactions B: Applications 2018;31.

[210] Edhirej A, Sapuan SM, Jawaid M, Zahari NI. Cassava/sugar palm fiber reinforced cassava starch hybrid composites: Physical, thermal and structural properties. International Journal of Biological Macromolecules 2017;101. https://doi.org/10.1016/j.ijbiomac.2017.03.045.

[211] Cavalcanti DKK, Banea MD, Neto JSS, Lima RAA, da Silva LFM, Carbas RJC. Mechanical characterization of intralaminar natural fibre-reinforced hybrid composites. Composites Part B: Engineering 2019;175:107149. https://doi.org/10.1016/j.compositesb.2019.107149.

[212] Almeida JHS, Amico SC, Botelho EC, Amado FDR. Hybridization effect on the mechanical properties of curaua/glass fiber composites. Composites Part B: Engineering 2013;55. https://doi.org/10.1016/j.compositesb.2013.07.014. 
[213] Almeida Júnior JHS, Ornaghi Júnior HL, Amico SC, Amado FDR. Study of hybrid intralaminate curaua/glass composites. Materials and Design 2012;42. https://doi.org/10.1016/j.matdes.2012.05.044.

[214] Neto JSS, Lima RAA, Cavalcanti DKK, Souza JPB, Aguiar RAA, Banea MD. Effect of chemical treatment on the thermal properties of hybrid natural fiber-reinforced composites. Journal of Applied Polymer Science 2019;136. https://doi.org/10.1002/app.47154.

[215] Prasanna Venkatesh R, Ramanathan K, Srinivasa Raman V. Tensile, flexual, impact and water absorption properties of natural fibre reinforced polyester hybrid composites. Fibres and Textiles in Eastern Europe 2016;24. https://doi.org/10.5604/12303666.1196617.

[216] Sudhir.A. Tensile and Flexural Properties of Sisal / Jute Hybrid Natural Fiber Composites. Journal Of Modern Engineering Research (IJMER) 2014;4.

[217] Ramesh M, Palanikumar K, Reddy KH. Mechanical property evaluation of sisal-juteglass fiber reinforced polyester composites. Composites Part B: Engineering 2013;48. https://doi.org/10.1016/j.compositesb.2012.12.004.

[218] Ornaghi HL, da Silva HSP, Zattera AJ, Amico SC. Hybridization effect on the mechanical and dynamic mechanical properties of curaua composites. Materials Science and Engineering A 2011;528. https://doi.org/10.1016/j.msea.2011.05.078.

[219] Fragassa C. Effect of natural fibers and bio-resins on mechanical properties in hybrid and non-hybrid composites. AIP Conference Proceedings, vol. 1736, 2016. https://doi.org/10.1063/1.4949693.

[220] Boopalan M, Niranjanaa M, Umapathy MJ. Study on the mechanical properties and thermal properties of jute and banana fiber reinforced epoxy hybrid composites. $\begin{array}{llll}\text { Composites } & \text { Part } & \text { B } & \text { Engineering }\end{array}$ https://doi.org/10.1016/j.compositesb.2013.02.033.

[221] I AA. Mechanical Properties of Plants - Synthetic Hybrid Fibers Composites. Research Journal of Engineering Sciences 2012;1. https://doi.org/10.13140/RG.2.1.3725.3845. 
[222] Swolfs Y, Gorbatikh L, Verpoest I. Fibre hybridisation in polymer composites: A review. Composites Part A: Applied Science and Manufacturing 2014;67. https://doi.org/10.1016/j.compositesa.2014.08.027.

[223] Budhe S, de Barros S, Banea MD. Theoretical assessment of the elastic modulus of natural fiber-based intra-ply hybrid composites. Journal of the Brazilian Society of Mechanical Sciences and Engineering 2019;41. https://doi.org/10.1007/s40430-0191766-z.

[224] Mittal V, Saini R, Sinha S. Natural fiber-mediated epoxy composites - A review. $\begin{array}{llll}\text { Composites } & \text { Part } & \text { B } & \text { Engineering }\end{array}$ https://doi.org/10.1016/j.compositesb.2016.06.051.

[225] Wambua P, Ivens J, Verpoest I. Natural fibres: Can they replace glass in fibre reinforced plastics? Composites Science and Technology 2003;63. https://doi.org/10.1016/S02663538(03)00096-4.

[226] Pickering KL, Efendy MGA, Le TM. A review of recent developments in natural fibre composites and their mechanical performance. Composites Part A: Applied Science and Manufacturing 2016;83. https://doi.org/10.1016/j.compositesa.2015.08.038.

[227] Papa I, Boccarusso L, Langella A, Lopresto V. Carbon/glass hybrid composite laminates in vinylester resin: Bending and low velocity impact tests. Composite Structures 2020. https://doi.org/10.1016/j.compstruct.2019.111571.

[228] Zhang C, Rao Y, Li Z, Li W. Low-velocity impact behavior of interlayer/intralayer hybrid composites based on carbon and glass non-crimp fabric. Materials 2018. https://doi.org/10.3390/ma11122472.

[229] Chen D, Luo Q, Meng M, Sun G. Low velocity impact behavior of interlayer hybrid composite laminates with carbon/glass/basalt fibres. Composites Part B: Engineering 2019. https://doi.org/10.1016/j.compositesb.2019.107191.

[230] Tirillò J, Ferrante L, Sarasini F, Lampani L, Barbero E, Sánchez-Sáez S, et al. High velocity impact behaviour of hybrid basalt-carbon/epoxy composites. Composite Structures 2017. https://doi.org/10.1016/j.compstruct.2017.02.039. 
[231] Papa I, Ricciardi MR, Antonucci V, Pagliarulo V, Lopresto V. Impact behaviour of hybrid basalt/flax twill laminates. Composites Part B: Engineering 2018. https://doi.org/10.1016/j.compositesb.2018.07.025.

[232] Ismail MF, Sultan MTH, Hamdan A, Shah AUM, Jawaid M. Low velocity impact behaviour and post-impact characteristics of kenaf/glass hybrid composites with various weight ratios. Journal of Materials Research and Technology 2019. https://doi.org/10.1016/j.jmrt.2019.04.005.

[233] Bar M, Alagirusamy R, Das A, Ouagne P. Low velocity impact response of flax/polypropylene hybrid roving based woven fabric composites: Where does it stand with respect to GRPC? Polymer Testing 2020. https://doi.org/10.1016/j.polymertesting.2020.106565.

[234] Xu Y, Chen X, Wang Y, Yuan Z. Stabbing resistance of body armour panels impregnated with shear thickening fluid. Composite Structures 2017;163. https://doi.org/10.1016/j.compstruct.2016.12.056.

[235] Barnes HA. Shear-Thickening ("Dilatancy") in Suspensions of Nonaggregating Solid Particles Dispersed in Newtonian Liquids. Journal of Rheology 1989. https://doi.org/10.1122/1.550017.

[236] Chhabra RP, Richardson JF. Non-Newtonian fluid behaviour. Non-Newtonian Flow in the Process Industries, 1999. https://doi.org/10.1016/b978-075063770-1/50002-6.

[237] Egres RG, Wagner NJ. The rheology and microstructure of acicular precipitated calcium carbonate colloidal suspensions through the shear thickening transition. Journal of Rheology 2005. https://doi.org/10.1122/1.1895800.

[238] Hu YT, Boltenhagen P, Pine DJ. Shear thickening in low-concentration solutions of wormlike micelles. I. Direct visualization of transient behavior and phase transitions. Journal of Rheology 1998. https://doi.org/10.1122/1.550926.

[239] Kaldasch J, Senge B. Shear thickening in polymer stabilized colloidal suspensions. Colloid and Polymer Science 2009. https://doi.org/10.1007/s00396-009-2121-1.

[240] White EEB, Chellamuthu M, Rothstein JP. Extensional rheology of a shear-thickening cornstarch and water suspension. Rheologica Acta 2010. https://doi.org/10.1007/s00397-009-0415-3. 
[241] Frith WJ, d'Haene P, Buscall R, Mewis J. Shear thickening in model suspensions of sterically stabilized particles. Journal of Rheology 1996. https://doi.org/10.1122/1.550791.

[242] Balali E, Kordani N, Sadough Vanini A. Response of glass fiber-reinforced hybrid shear thickening fluid (STF) under low-velocity impact. Journal of the Textile Institute 2017. https://doi.org/10.1080/00405000.2016.1166853.

[243] Fu K, Wang H, Chang L, Foley M, Friedrich K, Ye L. Low-velocity impact behaviour of a shear thickening fluid (STF) and STF-filled sandwich composite panels. $\begin{array}{llll}\text { Composites } & \text { Science } & \text { Technology }\end{array}$ https://doi.org/10.1016/j.compscitech.2018.06.013.

[244] Lee YS, Wetzel ED, Wagner NJ. The ballistic impact characteristics of Kevlar ${ }^{\circledR}$ woven fabrics impregnated with a colloidal shear thickening fluid. Journal of Materials Science 2003. https://doi.org/10.1023/A:1024424200221.

[245] Selver E. Impact and damage tolerance of shear thickening fluids-impregnated carbon and glass fabric composites. Journal of Reinforced Plastics and Composites 2019. https://doi.org/10.1177/0731684419842648.

[246] Kim DY, Bang JH, Lee CA, Kim HY, Choi KY, Lim BG. Numerical evaluation of timedependent sagging for low density polyurethane foams to apply the long-term driving comfort on the seat cushion design. International Journal of Industrial Ergonomics 2018. https://doi.org/10.1016/j.ergon.2016.08.010.

[247] Marsavina L, Constantinescu DM, Linul E, Voiconi T, Apostol DA. Shear and mode II fracture of PUR foams. Engineering Failure Analysis 2015. https://doi.org/10.1016/j.engfailanal.2015.05.021.

[248] Mazari FB, Mazari A, Havelka A, Wiener J. Effect of a superabsorbent for the improvement of car seat thermal comfort. Fibres and Textiles in Eastern Europe 2017. https://doi.org/10.5604/12303666.1228187.

[249] Wu L, Wang J, Jiang Q, Lu Z, Wang W, Lin JH. Low-velocity impact behavior of flexible sandwich composite with polyurethane grid sealing shear thickening fluid core. $\begin{array}{lllll}\text { Journal of Sandwich } & \text { Structures and }\end{array}$ https://doi.org/10.1177/1099636219837701. 
[250] Caglayan C, Osken I, Ataalp A, Turkmen HS, Cebeci H. Impact response of shear thickening fluid filled polyurethane foam core sandwich composites. Composite Structures 2020. https://doi.org/10.1016/j.compstruct.2020.112171.

[251] Pinto F, Meo M. Design and Manufacturing of a Novel Shear Thickening Fluid Composite (STFC) with Enhanced out-of-Plane Properties and Damage Suppression. Applied Composite Materials 2017. https://doi.org/10.1007/s10443-016-9532-1.

[252] Asija N, Chouhan H, Gebremeskel SA, Bhatnagar N. Impact Response of Shear Thickening Fluid (STF) Treated High Strength Polymer Composites - Effect of STF $\begin{array}{llll}\text { Intercalation } & \text { Method. } & \text { Procedia } & \text { Engineering, }\end{array}$ https://doi.org/10.1016/j.proeng.2016.12.133.

[253] Lu Z, Yuan Z, Chen X, Qiu J. Evaluation of ballistic performance of STF impregnated fabrics under high velocity impact. Composite Structures 2019. https://doi.org/10.1016/j.compstruct.2019.111208.

[254] Abhishek MR, Suresh PM, Sreedhar Murthy HS. Evaluation of Mechanical Properties of Jute/E-Glass Epoxy Hybrid Composites by Varying Fibre Loading with and Without Shear Thickening Fluid. Materials Today: Proceedings, 2017. https://doi.org/10.1016/j.matpr.2017.08.039.

[255] Saleh M, Edwards L, Crouch IG. Numerical modelling and computer simulations. The Science of Armour Materials, 2017. https://doi.org/10.1016/b978-0-08-1007044.00009-8.

[256] Weerasinghe D, Mohotti D, Anderson J. Incorporation of shear thickening fluid effects into computational modelling of woven fabrics subjected to impact loading: A review. $\begin{array}{lllll}\text { International Journal of } & \text { Protective } & \text { Structures }\end{array}$ https://doi.org/10.1177/2041419619889071.

[257] Rizzo F, Pinto F, Meo M. Investigation of Silica-Based Shear Thickening Fluid in Enhancing Composite Impact Resistance. Applied Composite Materials 2020. https://doi.org/10.1007/s10443-020-09805-7.

[258] Sen S, Jamal M N bin, Shaw A, Deb A. Numerical investigation of ballistic performance of shear thickening fluid (STF)-Kevlar composite. International Journal of Mechanical Sciences 2019;164. https://doi.org/10.1016/j.ijmecsci.2019.105174. 
[259] Wetzel ED. The Effect of Rheological Parameters on the Ballistic Properties of Shear Thickening Fluid (STF)-Kevlar Composites, 2004. https://doi.org/10.1063/1.1766538.

[260] Hasanzadeh M, Mottaghitalab V, Rezaei M, Babaei H. Numerical and experimental investigations into the response of STF-treated fabric composites undergoing ballistic impact. Thin-Walled Structures 2017. https://doi.org/10.1016/j.tws.2017.07.020.

[261] Lee BW, Kim CG. Computational analysis of shear thickening fluid impregnated fabrics subjected to ballistic impacts. Advanced Composite Materials 2012. https://doi.org/10.1080/09243046.2012.690298.

[262] Chauhan V, Kumar A, Bhalla NA, Danish M, Ranjan V. Numerical study of shear thickening fluid with distinct particles dispersed in carrier fluid. Vibroengineering Procedia, 2018. https://doi.org/10.21595/vp.2018.20397.

[263] R S, G VV, Alexander AM. Bullet Proof Vest using Non-Newtonian Fluid. International Journal of Students' Research in Technology \& Management 2015. https://doi.org/10.18510/ijsrtm.2015.384.

[264] Black Sara. Future combat helmet: Promising prototype | CompositesWorld 2010. https://www.compositesworld.com/articles/future-combat-helmet-promising-prototype (accessed June 18, 2020).

[265] Tehrani M, Boroujeni AY, Hartman TB, Haugh TP, Case SW, Al-Haik MS. Mechanical characterization and impact damage assessment of a woven carbon fiber reinforced carbon nanotube-epoxy composite. Composites Science and Technology 2013;75:42-8. https://doi.org/10.1016/j.compscitech.2012.12.005.

[266] Lee YS, Wetzel ED, Wagner NJ. The ballistic impact characteristics of Kevlar ${ }^{\circledR}$ woven fabrics impregnated with a colloidal shear thickening fluid. Journal of Materials Science 2003. https://doi.org/10.1023/A:1024424200221.

[267] Rabb RJ, Fahrenthold EP. Simulation of large fragment impacts on shear-thickening fluid Kevlar fabric Barriers. Journal of Aircraft 2011. https://doi.org/10.2514/1.C031445.

[268] Ding J, Tracey P, Li W, Peng G, Whitten PG, Wallace GG. Review on Shear Thickening Fluids and Applications. Textiles and Light Industrial Science and Technology 2013. 
[269] Borella R.B. BRP, ATT, DHH,. Plastic hollow fiber containing a shear-thickening fluid for high tensile strength fibers 2008.

[270] Ganesan A, Yamada M, Fukumoto M. Cold spray coating deposition mechanism on the thermoplastic and thermosetting polymer substrates. Journal of Thermal Spray Technology, vol. 22, 2013. https://doi.org/10.1007/s11666-013-9984-x.

[271] Villafuerte J. Current and future applications of cold spray technology. Metal Finishing 2010;108. https://doi.org/10.1016/S0026-0576(10)80005-4.

[272] Zhou XL, Chen AF, Liu JC, Wu XK, Zhang JS. Preparation of metallic coatings on polymer matrix composites by cold spray. Surface and Coatings Technology 2011;206. https://doi.org/10.1016/j.surfcoat.2011.07.005.

[273] Villafuerte J. Recent trends in cold spray technology: Looking at the future. Surface Engineering 2010;26. https://doi.org/10.1179/026708410X12687356948715.

[274] Concustell A, Henao J, Dosta S, Cinca N, Cano IG, Guilemany JM. On the formation of metallic glass coatings by means of Cold Gas Spray technology. Journal of Alloys and Compounds 2015;651. https://doi.org/10.1016/j.jallcom.2015.07.270.

[275] Henao J, Concustell A, G.Cano I, Dosta S, Cinca N, Guilemany JM, et al. Novel Albased metallic glass coatings by Cold Gas Spray. Materials and Design 2016;94. https://doi.org/10.1016/j.matdes.2016.01.040.

[276] Goldbaum D, Shockley JM, Chromik RR, Rezaeian A, Yue S, Legoux JG, et al. The effect of deposition conditions on adhesion strength of Ti and Ti6Al4V cold spray splats Journal of Thermal Spray Technology 2012;21. https://doi.org/10.1007/s11666-0119720-3.

[277] Zhang P, Santoro G, Yu S, Vayalil SK, Bommel S, Roth S v. Manipulating the Assembly of Spray-Deposited Nanocolloids: In Situ Study and Monolayer Film Preparation Langmuir 2016;32. https://doi.org/10.1021/acs.langmuir.6b00892.

[278] Russo P, Langella A, Papa I, Simeoli G, Lopresto V. Thermoplastic polyurethane/glass fabric composite laminates: Low velocity impact behavior under extreme temperature $\begin{array}{llll}\text { conditions. } & \text { Composite } & \text { Structures }\end{array}$ https://doi.org/10.1016/j.compstruct.2017.01.054. 
[279] Zhou XL, Chen AF, Liu JC, Wu XK, Zhang JS. Preparation of metallic coatings on polymer matrix composites by cold spray. Surface and Coatings Technology 2011;206. https://doi.org/10.1016/j.surfcoat.2011.07.005.

[280] Che H, Chu X, Vo P, Yue S. Metallization of Various Polymers by Cold Spray. Journal of Thermal Spray Technology 2018;27. https://doi.org/10.1007/s11666-017-0663-1.

[281] Chen C, Xie X, Xie Y, Yan X, Huang C, Deng S, et al. Metallization of polyether ether ketone (PEEK) by copper coating via cold spray. Surface and Coatings Technology 2018;342:209-19. https://doi.org/10.1016/j.surfcoat.2018.02.087.

[282] Astarita A, Boccarusso L, Durante M, Viscusi A, Sansone R, Carrino L. Study of the Production of a Metallic Coating on Natural Fiber Composite Through the Cold Spray Technique. Journal of Materials Engineering and Performance 2018;27. https://doi.org/10.1007/s11665-018-3147-7.

[283] Lupoi R, O’Neill W. Deposition of metallic coatings on polymer surfaces using cold spray. Surface and Coatings Technology 2010;205:2167-73. https://doi.org/10.1016/j.surfcoat.2010.08.128.

[284] Che H, Vo P, Yue S. Metallization of carbon fibre reinforced polymers by cold spray. Surface and Coatings Technology 2017;313:236-47. https://doi.org/10.1016/j.surfcoat.2017.01.083.

[285] Fallah P, Rajagopalan S, McDonald A, Yue S. Development of hybrid metallic coatings on carbon fiber-reinforced polymers (CFRPs) by cold spray deposition of copperassisted copper electroplating process. Surface and Coatings Technology 2020:126231. https://doi.org/10.1016/j.surfcoat.2020.126231.

[286] Papa I, Russo P, Astarita A, Viscusi A, Perna AS, Carrino L, et al. Impact behaviour of a novel composite structure made of a polymer reinforced composite with a $3 \mathrm{D}$ printed $\begin{array}{llll}\text { metallic coating. } & \text { Composite } & \text { Structures }\end{array}$ https://doi.org/10.1016/j.compstruct.2020.112346.

[287] Sun X, Tong L, Wood MDK, Mai YW. Effect of stitch distribution on mode I delamination toughness of laminated DCB specimens. Composites Science and Technology 2004;64. https://doi.org/10.1016/j.compscitech.2003.07.004. 
[288] Tsai GC, Chen JW. Effect of stitching on Mode I strain energy release rate. Composite Structures 2005;69. https://doi.org/10.1016/j.compstruct.2004.02.009.

[289] Rong MZ, Zhang MQ, Liu Y, Zhang ZW, Yang GC, Zeng HM. Effect of stitching on in-plane and interlaminar properties of sisal/epoxy laminates. Journal of Composite Materials 2002;36. https://doi.org/10.1177/0021998302036012163.

[290] Ravandi M, Teo WS, Tran LQN, Yong MS, Tay TE. The effects of through-thethickness stitching on the Mode I interlaminar fracture toughness of flax/epoxy composite laminates. Materials and Design 2016;109:659-69. https://doi.org/10.1016/j.matdes.2016.07.093.

[291] Rong MZ, Zhang MQ, Liu Y, Zhang ZW, Yang GC, Zeng HM. Effect of stitching on in-plane and interlaminar properties of sisal/epoxy laminates. Journal of Composite Materials 2002;36. https://doi.org/10.1177/0021998302036012163.

[292] Ravandi M, Teo WS, Tran LQN, Yong MS, Tay TE. The effects of through-thethickness stitching on the Mode I interlaminar fracture toughness of flax/epoxy composite laminates. Materials and Design 2016;109:659-69. https://doi.org/10.1016/j.matdes.2016.07.093.

[293] Ravandi M, Teo WS, Tran LQN, Yong MS, Tay TE. Low velocity impact performance of stitched flax/epoxy composite laminates. Composites Part B: Engineering 2017;117. https://doi.org/10.1016/j.compositesb.2017.02.003.

[294] Li S, Zheng T, Li Q, Hu Y, Wang B. Flexural and energy absorption properties of natural-fiber reinforced composites with a novel fabrication technique. Composites Communications 2019;16. https://doi.org/10.1016/j.coco.2019.09.005.

[295] Habibi M, Laperrière L, Mahi Hassanabadi H. Replacing stitching and weaving in natural fiber reinforcement manufacturing, part 1: mechanical behavior of unidirectional flax fiber composites. Journal of Natural Fibers 2019;16. https://doi.org/10.1080/15440478.2018.1448321.

[296] Francesconi L, Aymerich F. Effect of Z-pinning on the impact resistance of composite laminates with different layups. Composites Part A: Applied Science and Manufacturing 2018;114:136-48. https://doi.org/10.1016/j.compositesa.2018.08.013. 
[297] Zhang X, Hounslow L, Grassi M. Improvement of low-velocity impact and compression-after-impact performance by z-fibre pinning. Composites Science and Technology 2006;66. https://doi.org/10.1016/j.compscitech.2006.02.029.

[298] Hoffmann J, Brast A, Scharr G. Z-pin insertion process for through-thickness reinforced thermoplastic composites. Journal of Composite Materials 2019;53. https://doi.org/10.1177/0021998318781233.

[299] Naik NK, Ramasimha R, Arya H, Prabhu S v., ShamaRao N. Impact response and damage tolerance characteristics of glass-carbon/epoxy hybrid composite plates. Composites Part B:Engineering 2001;32. https://doi.org/10.1016/S13598368(01)00036-1.

[300] Pegoretti A, Fabbri E, Migliaresi C, Pilati F. Intraply and interply hybrid composites based on E-glass and poly(vinyl alcohol) woven fabrics: Tensile and impact properties. Polymer International 2004;53. https://doi.org/10.1002/pi.1514.

[301] Wang X, Hu B, Feng Y, Liang F, Mo J, Xiong J, et al. Low velocity impact properties of 3D woven basalt/aramid hybrid composites. Composites Science and Technology 2008;68. https://doi.org/10.1016/j.compscitech.2007.06.016.

[302] Pegoretti A, Fabbri E, Migliaresi C, Pilati F. Intraply and interply hybrid composites based on E-glass and poly(vinyl alcohol) woven fabrics: Tensile and impact properties. Polymer International 2004;53. https://doi.org/10.1002/pi.1514.

[303] Sinmazçelik T, Avcu E, Bora MÖ, Çoban O. A review: Fibre metal laminates, background, bonding types and applied test methods. Materials and Design 2011;32:3671-85. https://doi.org/10.1016/j.matdes.2011.03.011.

[304] Chang PY, Yeh PC, Yang JM. Fatigue crack initiation in hybrid boron/glass/aluminum fiber metal laminates. Materials Science and Engineering A 2008;496. https://doi.org/10.1016/j.msea.2008.07.041.

[305] Dhar Malingam S, Jumaat FA, Ng LF, Subramaniam K, Ab Ghani AF. Tensile and impact properties of cost-effective hybrid fiber metal laminate sandwich structures. Advances in Polymer Technology 2018;37. https://doi.org/10.1002/adv.21913. 
[306] Kuan HTN, Cantwell WJ, Hazizan MA, Santulli C. The fracture properties of environmental-friendly fiber metal laminates. Journal of Reinforced Plastics and Composites 2011;30. https://doi.org/10.1177/0731684411398536.

[307] Shen Y, Zhong J, Cai S, Ma H, Qu Z, Guo Y, et al. Effect of temperature and water absorption on low-velocity impact damage of composites with multi-layer structured flax fiber. Materials 2019;12. https://doi.org/10.3390/ma12030453.

[308] Suresh Kumar C, Arumugam V, Dhakal HN, John R. Effect of temperature and hybridisation on the low velocity impact behavior of hemp-basalt/epoxy composites. Composite Structures 2015;125:407-16. https://doi.org/10.1016/j.compstruct.2015.01.037.

[309] Mueller DH. Improving the Impact Strength of Natural Fiber Reinforced Composites by Specifically Designed Material and Process Parameters. International Nonwovens Journal 2004;os-13. https://doi.org/10.1177/1558925004os-1300405.

[310] Dhakal HN, Arumugam V, Aswinraj A, Santulli C, Zhang ZY, Lopez-Arraiza A. Influence of temperature and impact velocity on the impact response of jute/UP composites. Polymer Testing 2014;35:10-9. https://doi.org/10.1016/j.polymertesting.2014.02.002.

[311] David-West OS, Banks WM, Pethrick RA. A study of the effect of strain rate and temperature on the characteristics of quasi-unidirectional natural fibre-reinforced composites. Proceedings of the Institution of Mechanical Engineers, Part L: Journal of Materials: Design and Applications 2011;225:133-48. https://doi.org/10.1177/0954420711404635.

[312] Singh JIP, Singh S, Dhawan V. Effect of Curing Temperature on Mechanical Properties of Natural Fiber Reinforced Polymer Composites. Journal of Natural Fibers 2018;15:687-96. https://doi.org/10.1080/15440478.2017.1354744.

[313] Deo C, Acharya SK. Effect of Moisture Absorption on Mechanical Properties of Chopped Natural Fiber Reinforced Epoxy Composite. Journal of Reinforced Plastics and Composites 2010;29:2513-21. https://doi.org/10.1177/0731684409353352.

[314] Karmaker AC, Youngquist JA. Injection molding of polypropylene reinforced with short jute fibers. Journal of Applied Polymer Science 1996;62. 
https://doi.org/10.1002/(SICI)1097-4628(19961121)62:8<1147::AID-APP2>3.0.CO;2I.

[315] Odusote J, Kumar V. Mechanical Properties of Pineapple Leaf Fibre Reinforced Polymer Composites for Application as Prosthetic Socket. Journal of Engineering Technology 2016;6. https://doi.org/10.21859/jet-06011.

[316] Chen X, Guo Q, Mi Y. Bamboo fiber-reinforced polypropylene composites: A study of the mechanical properties. Journal of Applied Polymer Science 1998;69. https://doi.org/10.1002/(SICI)1097-4628(19980906)69:10<1891::AID-

APP1>3.0.CO;2-9.

[317] Karmaker AC. Effect of water absorption on dimensional stability and impact energy of jute fibre reinforced polypropylene. Journal of Materials Science Letters 1997;16:4624. https://doi.org/10.1023/A:1018508209022.

[318] Živković I, Fragassa C, Pavlović A, Brugo T. Influence of moisture absorption on the impact properties of flax, basalt and hybrid flax/basalt fiber reinforced green composites. Composites Part B: Engineering 2017;111:148-64. https://doi.org/10.1016/j.compositesb.2016.12.018.

[319] Fiore V, Scalici T, Calabrese L, Valenza A, Proverbio E. Effect of external basalt layers on durability behaviour of flax reinforced composites. Composites Part B: Engineering 2016;84. https://doi.org/10.1016/j.compositesb.2015.08.087.

[320] Wang A, Wang X, Xian G. Mechanical, low-velocity impact, and hydrothermal aging properties of flax/carbon hybrid composite plates. Polymer Testing 2020:106759. https://doi.org/10.1016/j.polymertesting.2020.106759.

[321] Dhakal HN, Zhang ZY, Guthrie R, MacMullen J, Bennett N. Development of flax/carbon fibre hybrid composites for enhanced properties. Carbohydrate Polymers 2013;96. https://doi.org/10.1016/j.carbpol.2013.03.074.

[322] Islam MS, Pickering KL, Foreman NJ. Influence of Hygrothermal Ageing on the Physico-Mechanical Properties of Alkali Treated Industrial Hemp Fibre Reinforced Polylactic Acid Composites. Journal of Polymers and the Environment 2010;18. https://doi.org/10.1007/s10924-010-0225-9. 
[323] Ravishankar B, Nayak SK, Kader MA. Hybrid composites for automotive applications - A review. Journal of Reinforced Plastics and Composites 2019. https://doi.org/10.1177/0731684419849708.

[324] Hung P yan, Lau K tak, Cheng L kwan, Leng J, Hui D. Impact response of hybrid carbon/glass fibre reinforced polymer composites designed for engineering applications. $\begin{array}{llll}\text { Composites } & \text { Part } & \text { B } & \text { Engineering }\end{array}$ https://doi.org/10.1016/j.compositesb.2017.09.026.

[325] Loganathan K, Baskar S, Karikalan L, Chandrasekran M, Ramasubramanian S. IJSRST1173174 | Hybridization of Composites using Natural and Synthetic Fibers for Automotive Application Hybridization of Composites using Natural and Synthetic Fibers for Automotive Application 2017;3:31.

[326] Da Luz FS, Junior EPL, Louro LHL, Monteiro SN. Ballistic test of multilayered armor with intermediate epoxy composite reinforced with jute fabric. Materials Research, 2015. https://doi.org/10.1590/1516-1439.358914.

[327] Wambua P, Vangrimde B, Lomov S, Verpoest I. The response of natural fibre composites to ballistic impact by fragment simulating projectiles. Composite Structures 2007. https://doi.org/10.1016/j.compstruct.2005.07.006.

[328] Campbell DT, Cramer DR. Hybrid thermoplastic composite ballistic helmet fabrication study. International SAMPE Symposium and Exhibition (Proceedings), vol. 52, 2008.

[329] Bajpai PK, Ram K, Gahlot LK, Jha VK. Fabrication of Glass/Jute/Epoxy Composite Based Industrial Safety Helmet. Materials Today: Proceedings, vol. 5, Elsevier Ltd; 2018, p. 8699-706. https://doi.org/10.1016/j.matpr.2017.12.296.

[330] Murali B, Nagarani J. Design and fabrication of construction helmet by using hybrid composite material. 2013 International Conference on Energy Efficient Technologies for Sustainability, ICEETS 2013, 2013. https://doi.org/10.1109/ICEETS.2013.6533372.

[331] Bilisik K. Impact-resistant fabrics (ballistic/stabbing/slashing/spike). Engineering of High-Performance Textiles, Elsevier; 2017, p. 377-434. https://doi.org/10.1016/B9780-08-101273-4.00014-7. 